
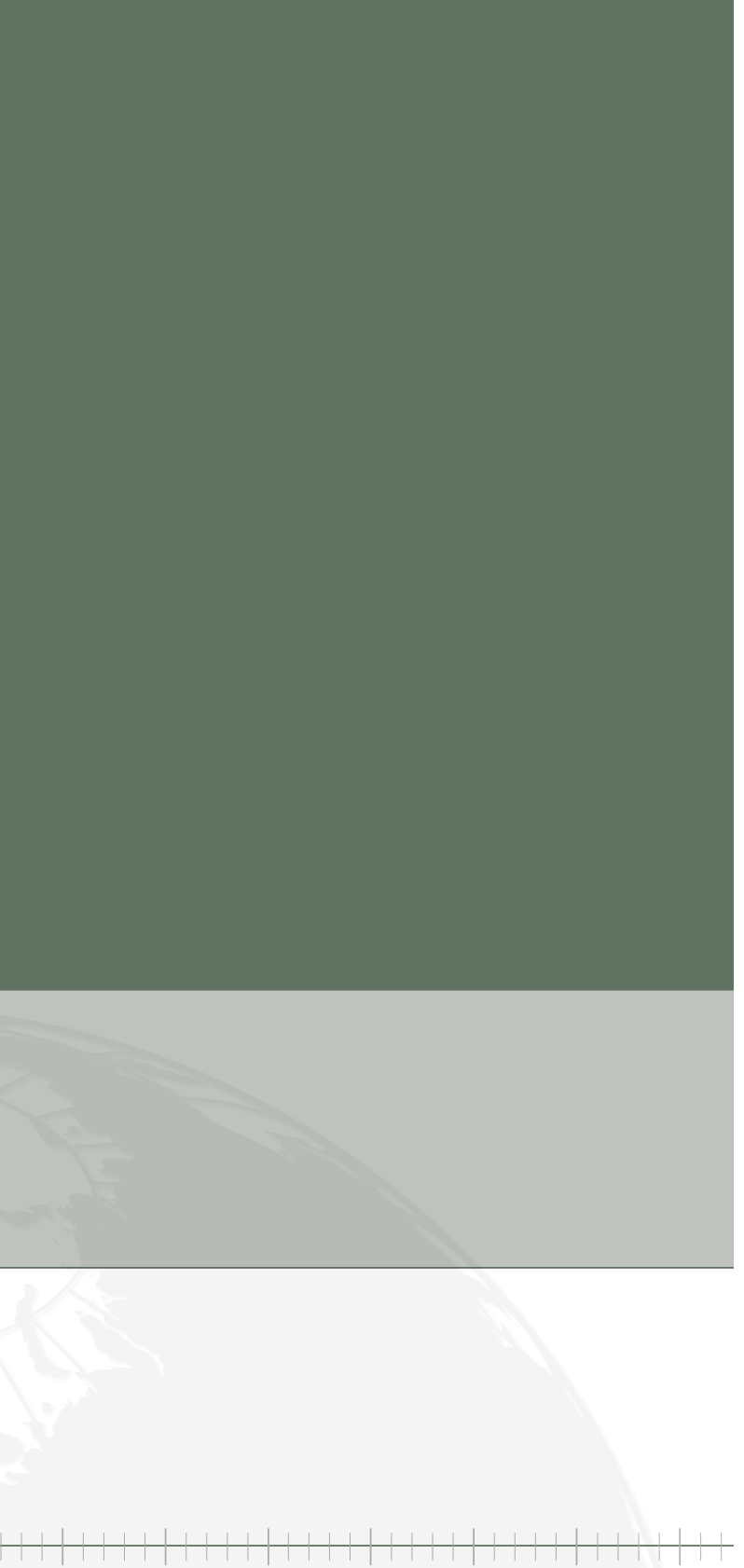
Contemporary Military Challenges

Znanstveno-strokovna publikacija Slovenske vojske

ISSN 2463-9575
UDK 355.5(477.94)(055)
November 2021- 23/st. 4 
Izdajatelj

Publisher

Glavni urednik

Executive Editor

Odgovorna urednica

Managing Editor

Uredniški odbor

Editorial Board

Sekretarka

Secretary

Uredniški svet

Editorial Council

Prevajanje

Translation

Lektoriranje

Proofreading

Oblikovanje

Design \& Graphic

Tisk

Print

ISSN

Naklada

Edition

Revija je dostopna

na spletni stran

Publication web page

E-naslov urednice

Managing Editor

e-mail address
Generalštab Slovenske vojske

General Staff of the Slovenian Armed Forces

brigadir Roman Urbanč (OF-6)

dr. Liliana Brožič

višja vojaška uslužbenka XIV. razreda dr. Valerija Bernik (OF-5)

višji vojaški uslužbenec XIV. razreda dr. Denis Caleta (OF-5)

polkovnik dr. Tomaž Kladnik (OF-5)

dr. Igor Kotnik

dr. Maja Garb

dr. Tibor Szvircsev Tresch, Militärakademie an der ETH, Zürich

dr. Thomas Young, Center for Civil-Military Relations, Monterey

višja praporščakinja Nataša Cankar (OR-9)

dr. Andrej Anžič, Evropska pravna fakulteta, Nova Gorica

dr. Gorazd Bajc, Narodna in študijska knjižnica, Trst

dr. Anton Bebler, Fakulteta za družbene vede, Ljubljana

dr. Bastian Giegerich, International Institute for Strategic Studies, London

dr. Olivera Injac, Univerzitet Donja Gorica, Podgorica

dr. Sergei Konoplyev, Harvard University, Cambridge

dr. Julie T. Manta, US Army War College, Carlisle

dr. Thomas Mockaitis, DePaul University, Chicago

dr. Klaus Olshausen (OF-8, ret.), Clausewitz-Gesellschaft e.V., Hamburg

generalpodpolkovnik dr. Iztok Podbregar (OF-8), Fakulteta za organizacijske vede, Kranj

Iris Žnidarič, Ana Hazler

Justy Carey, Marjetka Brulec, Vesna Vrabič

Skupina Opus Design

Grafex, d. o. o.

2232-2825 (tiskana različica/print version)

2463-9575 (spletna različica/online version)

300 izvodov/copies

Izhaja štirikrat na leto/Four issues per year

https://dk.mors.si/sodobni-vojaski-izzivi

https://dk.mors.si/sodobni-vojaski-izzivi

liliana.brozic@mors.si

Prispevki, objavljeni v Sodobnih vojaških izzivih, niso uradno stališče Slovenske vojske niti organov, iz katerih so avtorji prispevkov.

Publikacija je uvrščena v bibliografsko zbirko podatkov COBISS.SI, PAIS International ProQuest, Crossref, Military and Government Collection EBSCO in Air University Library Index in Military Periodicals.

Articles, published in the Contemporary Military Challenges do not reflect the official viewpoint of the Slovenian Armed Forces nor the bodies in which the authors of articles are employed.

The publication is indexed in bibliography databases COBISS.SI, PAIS International ProQuest, Crossref, Military and Government Collection EBSCO and Air University Library Index in Military Periodicals. 


\section{POSAMEZNIK, DRŽAVA, VARNOST}

»Nacionalna varnost je prva dolžnost vlade, vendar smo zavezani tudi temu, da preprečimo znatno zmanjšanje državljanskih svoboščin.«

Theresa May, izjava notranje ministrice, 13. julij 2010

\section{INDIVIDUAL, STATE, SECURITY}

"National security is the first duty of government but we are also committed to reversing the substantial erosion of civil liberties. "

Theresa May, Statement from the Home Secretary, 13 July 2010 



\section{VSEBINA}

CONTENTS

7

Liliana Brožič

UVODNIK

POSAMEZNIK, DRŽAVA, VARNOST

9

Liliana Brožič

EDITORIAL

INDIVIDUAL, STATE, SECURITY

13

Bruno Blažina

SAMOMORILNOST V POLICIJI

SUICIDALITY IN THE POLICE

29

Małgorzata Zielińska

JAVNO MNENJE O TERITORIALNI OBRAMBI POLJSKE THE PUBLIC'S PERCEPTION OF THE TERRITORIAL

DEFENCE FORCES IN POLAND

49

Gabriella Ráczkevy-Deák NASILNA DEJANJA NAD ZDRAVSTVENIMI USTANOVAMI IN NJIHOVIM ZAPOSLENIMI NA MADŽARSKEM

VIOLENT ACTS AGAINST HEALTHCARE INSTITUTIONS AND WORKERS IN HUNGARY

73

Rok Filipčič

KULTURNA DEDIŠČINA IN NJENO VAROVANJE V ČASU OBOROŽENIH SPOPADOV

CULTURAL HERITAGE AND ITS PROTECTION IN ARMED CONFLICTS

91

Uroš Tovornik

RECENZIJA

GEOPOLITIKA SLOVENIJE 
A GEOPOLITICS OF SLOVENIA

99

Liliana Brožič

RECENZIJA

MIROVNIKI V DARFURJU

103

Liliana Brožič

REVIEW

DARFUR PEACEKEEPERS

107

David Humar

RECENZIJA

O VOJAŠKIH STRATEGIJAH

111

REVIEW

ON MILITARY STRATEGIES

115

AVTORJI

AUTHORS

120

NAVODILA ZA AVTORJE

124

INSTRUCTIONS TO AUTHORS 


\section{UVODNIK}

\section{POSAMEZNIK, DRZ̈AVA. VARNOST}

V zadnji številki Sodobnih vojaških izzivov leta 2021 smo se posvetili nekaterim zahtevnim vsebinam. Takih je sicer veliko, v tej številki pa smo se osredotočili predvsem na covid-19 in odzive, ki jih doživljata posameznik in država oziroma njeni predstavniki v državnih institucijah na področju varnosti. Pri tem imamo v mislih varnost posameznika kot vrednoto, ki je bistvena zanj osebno. To je še pomembneje takrat, ko stopa $\mathrm{v}$ stik z drugimi posamezniki, še posebej s tistimi, ki delajo v državnih ustanovah. Na koncu pa je pomembna tudi varnost države kot najširše množice posameznikov.

V času, ki ga je zaznamoval covid-19, je vsa pozornost posameznikov in družbe kot celote namenjena zdravju in varnosti ljudi. Pri zagotavljanju tega prihajajo vpleteni v zelo različne položaje, pri katerih so zaradi opravljanja svojega dela ogroženi tudi tisti, ki sicer skrbijo za druge. Komunikacija in način komuniciranja sta zelo pomembna v povsem običajnih okoliščinah. Kadar pa gre za posebne okoliščine, med katere spada čas, zaznamovan s covidom-19, je komunikacija toliko pomembnejša.

O pomenu komunikacije v času covida-19 je nedavno pisal tudi Igor Kotnik v prilogi Objektiva v časniku Dnevnik. V prispevku z naslovom Od strahu k miru omenja pomembnost upravljanja države in njenih institucij z družbenimi, množičnimi situacijami, občutki in odzivi. Navaja, da smo »za njihovo upravljanje z družbeno pogodbo poverili državi in njenim institucijam, ki naj bi s svojim delovanjem pri obvladovanju neprijetnih in nevarnih okoliščin čim bolj zmanjševale delež državljanov, ki bi se nanje odzivali z zanikanjem ali strahom«.

To je zelo zahteven proces, $v$ katerem so na preizkušnji znanje in integriteta prav vsakega na individualni ravni v domačem in službenem okolju. Pri poklicih, ki na državni ravni upravljajo krizo, ki jo je zaznamovala bolezen, so na preizkušnji predvsem veščine vodenja, medsebojni odnosi, upravljanje stresa, nastopanje $\mathrm{v}$ 
javnosti, samozaščitno ravnanje in upravljanje množic. Vse zato, da se občutek strahu, nezaupanja in negotovosti čim bolj zmanjša in se vzpostavi občutek varnosti s poudarkom na logičnih razlagah in razmišljanju, ki naj prevladajo nad nenadzorovanimi čustvi in morebitnimi stiskami. Primer covida-19 ima številne značilnosti krize. Kadar krizno obdobje traja dlje časa in je zelo specifično, lahko pride do resnih sprememb, včasih že kar zaskrbljujočih, na področju etike, morale, prava, človekovih pravic in družbenih vrednot pa tudi varnosti.

Prispevki v tej številki obravnavajo nekatere vidike spoprijemanja s posebnimi razmerami in okoliščinami, za katere so se avtorji odločili, da jih delijo z drugimi.

Bruno Blažina $\mathrm{v}$ prispevku $\mathrm{z}$ naslovom Samomorilnost $v$ policiji razkriva raziskovanje na tem področju in ga primerja $\mathrm{s}$ pojavnostjo in ukrepanjem $\mathrm{V}$ Slovenski vojski ter z nekaterimi tujimi državami, ki se spoprijemajo s tem pojavom bolj ali manj učinkovito. Ugotavlja, da se s pojavom samomorilnosti Slovenska vojska ukvarja sistemsko, v Policiji pa se to še ne dogaja. Predlaga nove ukrepe za preprečevanje samomorilnosti v tem državnem organu.

O javnem mnenju o teritorialni obrambi Poljske pišejo avtorice Małgorzata Zielińska, Joanna Latacz in Joanna Zauer. Teritorialno obrambo je Poljska uvedla v začetku leta 2017. Raziskovalke je najbolj zanimalo javno mnenje o nalogah, ki naj bi jih izvajala v sistemu poljske nacionalne varnosti. Teriotrialna obramba naj bi bila dejavna v sistemu zaščite in reševanja, skrbela za varnost prebivalcev in kritične infrastrukture ali pa morda tudi pri opravljanju vojaških nalog. Pri spoprijemanju s covidom-19 je poljska vlada vključila tudi svojo teritorialno obrambo.

Gabriella Ráczkevy-Deák je preučevala pojav nasilnih dejanj nad zdravstvenimi ustanovami in njihovimi zaposlenimi na Madžarskem. Njihovo profesionalno znanje na področju zdravstva pri spoprijemanju z nasilnimi pacienti, njihovimi družinski člani in tudi sodelavci niso dovolj za reševanje tovrstnih izzivov. Dodatno znanje in izkušnje tudi iz drugih vsebin so vedno bolj potrebni v državnih institucijah. Avtorica se je najbolj osredotočila na znanje na področju komuniciranja, samozavesti in samoobrambe ter predlagala nekaj sistemskih rešitev.

O kulturni dediščini in njenem varovanju $v$ času oboroženih spopadov piše Rok Filipčič. Predstavlja kronološki pregled razvoja tega področja, pomembne mejnike v novejši zgodovini in mednarodnem pravnem redu ter ukrepe, ki so bili vzpostavljeni za zaščito kulturne dediščine doma in v tujini. Avtor predstavlja slovenske uspehe in naučene lekcije ter daje poseben poudarek zaščiti tega področja z vidika vojaške organizacije. Vojaški muzej v okviru Ministrstva za obrambo Republike Slovenije posebej skrbi za zaščito vojaške kulturne dediščine v Sloveniji. 


\section{EDITORIAL}

The final issue of Contemporary Military Challenges in 2021 focuses on specific demanding topics. Despite the variety of such topics, this issue focuses mainly on Covid-19 and the situations it has created in the area of security, and how that has impacted individuals, the country as a whole, and its public institution representatives. The focus lies on the security of an individual as a value which is also crucial for the individual personally. This becomes even more important when the individual comes in contact with others, in particularly those who work in state institutions. Last but not least, the issue highlights the importance of the security of the state as the broadest multitude of individuals.

In the time marked by Covid-19, the attention of individuals and society as a whole has been focused on people's health and security. In trying to ensure the latter, the people involved in this process find themselves in variously difficult situations in which even those whose primary occupation is to provide care for others are in one way or another exposed to risks due to their work. Communication and the way in which we communicate are very important even in normal circumstances. In special circumstances, which the Covid-19 period definitely has been, communication is essential.

In his recent article published in the Dnevnik daily newspaper's Saturday supplement »Objektiv«, Igor Kotnik, who holds a PhD in defence studies, writes about the importance of communication in the times of Covid-19. In his article, entitled »Communication in the Times of Covid: From Fear to Peace $\ll$, he addresses the importance of the management conducted by the state and its institutions while taking into account the social, mass situations, feelings and responses. He writes that "we have entrusted their management to the state and its institutions by means of a contract, and the latter should strive to reduce the number of citizens who might 
respond to such situations with denial or fear through the work they put into the management of unpleasant and dangerous situations«.

This is a very difficult process, which puts to the test the knowledge and integrity of each person at an individual level in both the domestic and work environments. With regard to the professions in charge of managing the crisis marked by this disease at the national level, the main things put to the test are leadership skills, interpersonal relationships, stress management, public performance, self-protective behaviour, and managing the masses, all with the intent of minimizing the feeling of fear, mistrust and insecurity to the greatest extent possible, and establishing a feeling of security by emphasizing logical explanations and thinking, which should prevail over uncontrolled emotions and possible distress. The example of Covid-19 has many characteristics of a crisis. Whenever a crisis period lasts a long time and is very specific, it can lead to serious changes in the fields of ethics, morale, law, human rights, social values, and security, which can be quite alarming.

The papers in this issue address specific aspects of managing the special situations and circumstances that the authors have decided to share with others.

In his paper, Suicidality in the Police, Bruno Blažina reveals the research in this field and compares it to the occurrence of the phenomenon and the resulting intervention in the Slovenian Armed Forces and in certain foreign states which are dealing with this issue in a more or less effective way. He assesses that the Slovenian Armed Forces are addressing suicidality in the Slovenian Armed Forces in a systemic way, while the police have not yet established such a system. He proposes new measures for the prevention of suicidality in this state body.

Małgorzata Zielińska, Joanna Latacz and Joanna Zauer write about The public's perception of the Territorial Defence Forces in Poland. Poland introduced territorial defence at the beginning of 2017. The researchers focus mainly on the public opinion of its tasks, which the TDF is supposed to carry out within the Polish national security system. The territorial defence is supposed to be active in the system of protection, rescue and relief, be in charge of the safety of the inhabitants and critical infrastructure, and even participate in the implementation of military tasks. The Polish Government has included its territorial defence in the fight against Covid-19.

In her paper, Gabriella Ráczkevy-Deák studied the occurrence of Violent acts against healthcare institutions and workers in Hungary. Their expert knowledge in the field of healthcare does not suffice for confronting challenges such as violent patients, their family members, and even co-workers. In state institutions, additional knowledge and experience from other fields are becoming increasingly sought after. The author focuses mainly on knowledge in the field of communication, self-esteem and self-defence, and offers some system solutions. 
Rok Filipčič writes about Cultural heritage and its preservation in the times of armed conflict. He presents a chronological overview of the development of this field, the key milestones in contemporary history and in the international legal order, and the measures that were introduced for the purposes of protecting cultural heritage at home and abroad. The author presents Slovenian successes and lessons learned, and attributes special emphasis to the protection of this field from the aspect of a military organization. The Military Museum, working within the Ministry of Defence of the Republic of Slovenia, gives special attention to the protection of military cultural heritage in Slovenia. 


\section{SAMOMORILNOST V POLICIJI}

Povzetek Znanstvene ugotovitve kažejo na veliko verjetnost ponovitve samomora policista, ki je enkrat že poskušal storiti samomor, in problematizirajo zanesljivost psiholoških pregledov glede odločanja o omejitvi dostopa do orožja. Predstavljena je dobra praksa spoprijemanja s problematiko samomorilnosti med pripadniki Slovenske vojske, ki bi lahko pomenila vzorec za izvajanje ukrepov za zaščito policistov. Od leta 1991 se število samomorov v policiji postopoma zmanjšuje, kljub temu pa se od leta 2009 do 2020 zmerno povečuje, predvsem zaradi številčnejših samomorov v obdobju od leta 2018 do 2020. S statistično metodo Hi-kvadrat smo ugotovili, da številčnost samomorov v obdobju od leta 2018 do 2020 ni statistično značilna glede na obdobje od leta 2009 do 2017 oziroma je mejna.

Ključne

Samomor, samomorilnost, policija.

besede

Abstract The current scientific findings show a high probability of a recurrence of a suicide attempt with a police officer who has already tried to commit suicide. They problematize the reliability of psychological examinations for limited firearm access. The article presents good practice in confronting the issue of suicide among members of the Slovenian Armed Forces, which could serve as a model for the police officer protection measures. Since 1991, the number of suicides in the police has been gradually decreasing. However, in the period 2009-2020, the number has been moderately increasing, mainly due to the higher number of suicides in the period 2018-2020. With the statistic method Chi-squared test, we have established that the number of suicides in the period 2018-2020 is not statistically significant in comparison to the period 2009-2017, or its significance is borderline.

\section{Key words Suicide, suicidality, police.}


Uvod Samomorilnost v policiji je fenomen, ki že od nekdaj obstaja v strukturi policije, ukvarjanje s to problematiko pa je razvidno iz objavljenih strokovnih in znanstvenih člankov in publikacij. Značilna je specifičnost raziskovalnega področja, ki se deloma razlikuje od problematike samomorilnosti splošne populacije.

V članku smo opravili analizo in pregled aktualnih tujih znanstvenih spoznanj na področju problematike samomorilnosti $\mathrm{v}$ policiji in dognanja aplicirali na problematiko v slovenski policiji. Namen tovrstnih tujih raziskav in obenem tudi naše analize je ugotoviti trenutne trende, značilnosti samomorov v policiji ter na podlagi teh izsledkov predvideti prihodnje trende, na podlagi analize trenutnega stanja ter zbranih lastnih in tujih izkušenj pa predlagati primerne preventivne in kurativne ukrepe. Pri raziskavi in izvedbi posamičnih analiz smo si pomagali s splošnima premisama našega raziskovanja in podrobnejšim vpogledom v posamezna področja, povezana z raziskavo. Leta 2017 je bila izvedena obsežna analiza pojava samomorilnosti v slovenski policiji, ki je vključevala analizo primerov samomorov od leta 1948 do 2016, uradne podatke o samomorih pa je takrat posredovala policija (Blažina, 2017). Raziskava je pokazala, da se je količnik samomorilnosti ${ }^{1}$ v obdobju po osamosvojitvi leta 1991 konstantno zniževal tako v splošni populaciji Slovenije kot tudi v policiji (Blažina, 2017, str. 353-354). Naša analiza prikazuje in povzema tudi nekatere ugotovitve ter dobre prakse preprečevanja samomora med pripadniki Slovenske vojske (v nadaljevanju SV), ki so v času naborniškega sistema in pozneje med uvedbo profesionalizacije SV pripomogle $\mathrm{k}$ zmanjšanju tovrstne problematike in bi bile $\mathrm{v}$ nekaterih segmentih primerne tudi za redukcijo obsega problematike samomorilnosti v slovenski policiji.

\section{METODOLOGIJA}

V pripravah na izvedbo raziskave so nas v širšem smislu zanimali statistično gibanje pojava samomorilnosti $\mathrm{v}$ policiji ter pripravljenost in odzivanje policije na pojav samomorilnosti v njenih vrstah. Tako smo si zastavili dve premisi raziskovanja, in sicer nas je zanimalo, ali se številčnost samomorov v zadnjih desetih letih povečuje ali manjša in koliko je policija pripravljena na spoprijemanje s problematiko samomorilnosti v svojih vrstah. Posebej nas je zanimalo število primerov samomora v policiji od leta 2009 do 2020 in kakšne ukrepe je ta uvedla ter jih še uvaja za evidentiranje, preprečevanje, zmanjšanje ali obravnavo samomorov in samomorilno ogroženih policistov. Podrobneje nas je zanimalo tudi, kako in koliko policija upošteva aktualne domače in tuje smernice ter ugotovitve s področja ukrepov proti samomorilnosti. Da bi konkretneje preverili uspešnost spoprijemanja s problematiko samomorilnosti v policiji, smo opravili primerjavo urejenosti področja evidentiranja, preprečevanja in spoprijemanja s samomori v Slovenski vojski.

Količnik samomorilnosti je izračunan kot razmerje med številom policistov, zaposlenih v policiji v tekočem letu, in številom samomorov $v$ policiji $v$ istem letu ter $v$ sklepnem računu predstavlja podatek o številu samomorov na 100.000 prebivalcev v konkretni obravnavani skupini, torej o številu samomorov na 100.000 prebivalcev $v$ tekočem letu. 
Za izvedbo raziskave smo opravili študijo in primerjavo podatkov iz razpoložljive sodobne literature, objavljenih sodobnih znanstvenih člankov in domačih normativnih virov, ki se nanašajo na obravnavano področje raziskovanja. Podatke smo pridobili iz uradnih virov policije in Slovenske vojske ter Sindikata policistov Slovenije (SPS). Zbrane podatke smo sistematično uredili in jih za izvedbo raziskave statistično analizirali.

\section{PRIMERJAVA Z DRUGIMI POLICIJAMI IN MOŽNOST PREPREČEVANJA SAMOMOROV V POLICIJI}

Preučevanje samomorilnosti med pripadniki varnostnih organov je najbolj prisotno $\mathrm{v}$ zahodnih državah, predvsem $\mathrm{v}$ ZDA in državah zahodne Evrope. V zadnjih petih letih so bile izvedene znanstvene raziskave o pojavnosti samomorilnosti $\mathrm{V}$ policiji oziroma varnostnih organih in pridobljene pomembne ugotovitve, ki jih predstavljamo v nadaljevanju.

\subsection{Združene države Amerike}

Glede na objavljene rezultate raziskave o pojavnosti samomorov s strelnim orožjem med policisti in preostalim prebivalstvom so v ZDA samomori, storjeni s strelnim orožjem, najpogostejši način izvršitve samomora. Tako so $\mathrm{v}$ okviru projekta »HOPE²« v ZDA med splošno populacijo leta 2017 ugotovili približno 60 odstotkov vseh storjenih samomorov z orožjem. V ameriški zvezni državi Utah je ta delež med splošno populacijo še večji, in sicer okrog 80 odstotkov (Barber et al., 2019, str. 1695). Zaradi uspešnejšega preventivnega pristopa $\mathrm{k}$ zmanjšanju te problematike je bila v tej zvezni državi izvedena obsežna analiza stanja in vzročnosti, predlagani in izvedeni so bili tudi ukrepi. V raziskavi so ugotovili nekaj zanimivih dejstev, ki se nanašajo na splošno populacijo in bodo v pomoč pri splošnem razumevanju fenomena samomora. Ugotovitve, ki so zelo pomembne pri načrtovanju in izvajanju preventivnih ukrepov ter razumevanju samomora, so predvsem ugotovljen interval med samomorilno mislijo in izvedbo samomora, ki naj bi bil v povprečju deset minut ali manj. Študija je bila namreč izvedena tudi med posamezniki iz splošne populacije, ki so že enkrat poskušali storiti samomor z ustrelitvijo. Glede na omenjeno okoliščino je v trenutku obstoja samomorilne misli bistveno tudi to, ali je posamezniku na voljo orožje ali sredstvo za realizacijo samomora. Na podlagi statističnega preučevanja primerov samomora je bila ugotovljena povezava med poskusi samomorov in storjenimi samomori, saj so posamezniki, ki so v preteklosti že poskušali storiti samomor, nagnjeni k storitvi in dokončni realizaciji samomora, in sicer v kar 90 odstotkih. Zanimiva je tudi ugotovitev, da so posamezniki v času storitve samomora s strelnim orožjem orožje posedovali legalno in bi bili v 92 odstotkih psihično in fizično sposobni za posest orožja v primeru zdravniškega pregleda. Le 8 odstotkov oseb, ki so umrle zaradi samomora, bi bilo v primeru zdravniškega pregleda na dan storitve samomora lahko prepoznanih kot psihično neprimerni posestniki strelnega

\footnotetext{
2 Project HOPE - The People-to-People Health Foundation je nevladna organizacija $v$ ZDA, ki se ukvarja z vprašanji zdravstvene zaščite v ZDA (https://www.projecthope.org/).
} 
orožja zaradi psihičnih motenj ali bolezni. Glede na omenjeno sta za načrtovanje preventivnih ukrepov bistvenega pomena opazovanje in takojšen odziv sorodnikov in oseb, ki so blizu morebitnemu samomorilcu, da njegovo stisko prepoznajo in osebi pravočasno pomagajo, tudi z odtegnitvijo sredstev za storitev samomora in $\mathrm{s}$ čimprejšnjo zdravniško oziroma psihološko pomočjo. Pomembna je tudi izmenjava informacij med upravnimi organi in zdravstvenimi ustanovami o posameznikih s samomorilnimi nagnjenji, da se jim še pravočasno omeji dostop do sredstev, $s$ katerimi bi lahko storili samomor, $\mathrm{v}$ tem primeru z odvzemom legalnega strelnega orožja (Barber et al., 2019, str. 1695, 1701).

V ZDA je bila leta 2018 izvedena in objavljena metaanaliza objavljenih člankov o samomorilnosti med policisti. V okviru projekta je bilo analiziranih skupno 97 dokumentov in 44 že objavljenih člankov za obdobje od leta 1997 do 2016. Študija razpoložljivih članov in dokumentov, ki vsebujejo podatke o samomorilnosti med policisti v ZDA in drugih državah, ugotavlja, da ni mogoče z gotovostjo ugotoviti in določiti enotnih značilnosti korelacije samomorov v policiji in samomorov med splošno populacijo. Količnik samomorilnosti med policisti je po državah različen in se giblje od večjega do manjšega količnika glede na splošno populacijo. Kot glavni stresor med policisti, ki lahko vodi do samomora, so v študijah ugotavljali organizacijske dejavnike v policiji, obravnavanje stresnih dogodkov med službo, odklanjanje strokovne pomoči, kar je povezano s stigmatiziranjem »šibkosti« in policijsko subkulturo. Čezmerno uživanje alkohola in težave v družinskem življenju $\mathrm{v}$ analizi povezujejo $\mathrm{z}$ naravo stresnega policijskega dela in izmenskim delom (Violanti, Owens, McCaniles, Fekedulegn in Andrew, 2018, str. 141, 164).

\subsection{Portugalska}

V projektu, ki so ga leta 2019 in 2020 izvedli študenti in profesorji na Fakulteti za psihologijo Univerze v Portu na Portugalskem, izhaja, da je kritičen dejavnik pri povečanem tveganju za samomor med policisti prav neomejen in takojšen dostop do strelnega orožja. Primerjali so tudi količnik samomorilnosti med splošno (primerjalno) populacijo in portugalskimi policisti v obdobju od leta 2005 do 2014 ter ugotovili, da je bilo v omenjenem obdobju med portugalskimi policisti storjenih skupaj 39 samomorov, od tega 34 s strelnim orožjem oziroma 30 storjenih s službenim strelnim orožjem. Količnik samomorilnosti je tako v portugalski policiji za omenjeno obdobje 20,6 samomora na 100.000 prebivalcev, medtem ko je bil v istem obdobju med splošno populacijo količnik samomorilnosti 13,9 samomora na 100.000 prebivalcev. Kot pomanjkljivost izpostavljajo premajhen statistični vzorec, edina oseba ženskega spola, ki je storila samomor, pa je bila iz raziskave izključena. Kot pomanjkljivost izpostavljajo tudi pomanjkanje podatkov o samomorih med upokojenimi policisti in policisti, ki so bili odpuščeni (Costa, Passos in Queirós, 2019). 


\subsection{Italija}

V Italiji je bila izvedena podrobna analiza samomorov med policisti državne policije (Polizia di Stato) za obdobje od leta 1995 do 2017, pri čemer so pridobljene podatke primerjali s splošno primerjalno populacijo (moški, mlajši od 65 let). Glede na analitično oziroma statistično obdelane podatke je v tem obdobju zaradi samomora v Italiji umrlo 271 policistov. Povprečni količnik samomorilnosti med italijanskimi policisti in policistkami je bil v tem obdobju (1995-2014) 11,78, v obdobju od leta 1995 do 2017 pa 11,62. Med splošno italijansko populacijo je bil količnik samomorilnosti v obdobju od leta 1995 do 2014 le 4,67 (moški in ženske skupaj). V omenjenem obdobju od leta 1995 do 2014 je bil količnik samomorilnosti med policisti moškega spola 12,67, med italijansko splošno moško populacijo pod 65 let pa 7,44. Kot zanimivost so ugotovili, da je stopnja samomorilnosti med italijanskimi policistkami 2,7-krat višja od primerjalne splošne ženske populacije v Italiji, vendar gre pri tem za analizo majhnega števila podatkov. Stopnja samomorilnosti se je vidno zmanjšala v obdobju od leta 1995 do 2007, nato pa bila v konstantnem stabilnem trendu do leta 2017. Celotno obdobje od leta 1995 do 2017 kaže na trend upadanja številčnosti samomora v italijanski državni policiji. Pri izvedbi analize so uporabili javno dostopne podatke italijanskega statističnega urada ISTAT $^{3}$ ter podatke o posameznih policistih, ki so storili samomor, in okoliščinah storitve samomora, ki jim jih je skupaj s splošnimi podatki o vsakoletnem številu vseh policistov državne policije posredovalo vodstvo italijanske državne policije (Grassi et al., 2019, str. 18, 23).

\section{UKREPI ZA PREPREČEVANJE SAMOMORILNOSTI V SLOVENSKI VOJSKI V ČASU UVEDBE NABORNIŠKEGA SISTEMA IN OBDOBJU PROFESIONALIZACIJE}

\subsection{Obdobje uvedbe naborniškega sistema}

Slovenska vojska se je v času po osamosvojitvi države oziroma med uvedbo naborniškega sistema spoprijemala $\mathrm{s}$ problematiko samomorov med svojimi pripadniki, pri čemer je bila še posebno pereča problematika pojavov samomorilnih teženj in primerov v času obstoja naborniškega sistema SV (Plemenitaš - Fuchs, 2003, str. 30-32). Opravljena je bila strokovna in poglobljena analiza, ki jo je avgusta 1997 v SV izvedel Operativni oddelek Generalštaba SV (v nadaljevanju GŠSV), z naslovom Samomorilna dejanja v Slovenski vojski v obdobju od leta 1991 do julija 1997. V analizi so ugotovili, da je problematika samomorilnih teženj med pripadniki stalne sestave SV in psihološko nefiltriranimi naborniki precej uravnotežena, zaradi česar predlagajo izvedbo ukrepov za psihološko filtriranje kandidatov za zaposlitev v SV in pravilno razporejanje na delovne dolžnosti, ki so osebnostno primerne za vsakega posameznika. Ugotovili so tudi vzroke za približno polovico vseh izvršenih samomorov v SV, pri čemer prednjačijo predvsem neorganizacijski vzroki, povezani z zasebnim življenjem posameznika (ločitev od partnerja, prezadolženost, psihične

3 ISTAT-podatki, objavljeni na spletni strani http://www.istat.it/it/archivio/suicidi. 
motnje ali bolezni), organizacijski vzroki, povezani z delom v SV in obremenitvami vojakov, pa na to problematiko niso imeli bistvenega vpliva. Po izvedbi poglobljene analize GŠSV se je od avgusta 1997 do vključno leta 2002 številčnost samomorov med pripadniki SV bistveno zmanjšala, saj je bilo od leta 1991 do avgusta 1997 med pripadniki SV 38 samomorov, od avgusta 1997 do leta 2002 pa le šest (Plemenitaš - Fuchs, 2003, str. 42). SV je na podlagi analize začela za pripadnike SV izvajati intenzivno psihološko oskrbo, razvila boljšo čuječnost med njimi in izvedla ukrepe za krepitev homogenosti enot SV in pripadnosti službi ter še nekatere ukrepe, ki so vključili sodelovanje družine pripadnikov SV, in razvila skrb tudi zanje.

\subsection{Ukrepi Slovenske vojske pri preprečevanju pojava samomorilnosti med vojaki v času od uvajanja profesionalizacije do danes}

SV je z ukinitvijo naborniškega sistema in hkratno uvedbo profesionalizacije vojakov leta 2003 ustrezno prilagodila tudi preventivno dejavnost na področju pojava samomorilnosti med vojaki SV. Glede na že opisane izvedene preventivne ukrepe, ki jih je SV že izvajala v času naborniškega sistema, je te v času od uvedbe profesionalizacije vojakov od leta 2003 naprej samo še vsebinsko dopolnjevala. Ugotovimo lahko, da se običajen povod in dejavniki za izvedbo samomora med slovenskimi policisti in vojaki nekoliko razlikujejo. Med policisti je delež organizacijskih $^{4}$ in neorganizacijskih dejavnikov samomora (pri definiciji smo upoštevali dejavnike stresa v policiji (Huselja, 2017, str. 193)) razdeljen nekako na polovico, med vojaki pa je v večini primerov med vojaki razlog v neorganizacijskih dejavnikih oziroma v zasebnem življenju vojaka. Zato je SV začela kompleksneje reševati to problematiko in v svoje preventivne ukrepe vključila tudi družine vojakov. Z uvedbo vodnih in četnih zaupnikov v vojaških enotah so v SV (ZSSloV, 2007) omogočili lažje ugotavljanje težav in dvignili čuječnost glede hitrega zaznavanja težav med pripadniki SV med pripadniki enot ter omogočili hitrejšo izmenjavo podatkov med moštvom in nadrejenimi (Pravila službe v Slovenski vojski, 2009, člen 9). Strokovna komisija, sestavljena iz strokovnjakov Ministrstva za obrambo, pripadnikov SV in zunanjih strokovnjakov, je leta 2011 izvedla analizo samomorov v SV od leta 1994 do 2011 in podatke črpala iz poročil o samomorih in poskusih samomorov v enotah TO/SV. Samomorov je bilo v SV v navedenem obdobju 17 in 9 poskusov storitve samomora. Med vojaškimi osebami v 79 odstotkih prevladuje samopoškodba s strelnim orožjem, samomorov, skupaj s poskusi, z obešanjem pa je bilo skupno 6 odstotkov. Na podlagi izvedenih analiz je strokovna skupina strokovnjakov z Ministrstva za obrambo in iz SV ter zunanjih strokovnjakov na podlagi ukaza načelnika Generalštaba Slovenske vojske (GŠSV), št. 812-3/2011192 z dne 12. 7. 2011, pripravila Akcijski načrt za znižanje pogostosti pojavov samomorilnega vedenja na Ministrstvu za obrambo in v Slovenski vojski, ki ga je GŠSV izdal novembra 2011 (GŠSV, 2011). Na podlagi omenjenega akcijskega načrta je GŠSV izdal še preglednico odgovornih oseb, nosilcev in rokov izvedbe posameznih ukrepov, ki je priloga osnovnega načrta. V akcijskem načrtu je strokovna

4 Tipi dejavnikov stresa $v$ policiji so organizacijski, zunanji, osebni in stresorji, povezani z opravljanjem dela (Huselja, 2017, str. 193). 
komisija analizirala preteklo obdobje glede pojavnosti pojava samomorilnosti v SV in ugotovila, da je bil količnik samomorilnosti v SV precej višji v prvem desetletju po osamosvojitvi Slovenije. Glede na posamezne podatke rezultatov opravljene analize mešane komisije strokovnjakov, ki je za SV opravila analizo, izhaja, da je v času veljavnosti naborniškega sistema v SV med njenimi pripadniki prevladoval starejši stalni in nepoklicni kader (nad 30 let), prav tako pa je bil v tem obdobju delež pripadnic ženskega spola v SV zanemarljiv. Splošno je znano, da je med osebami ženskega spola samomorilnost manj prisotna. Naslednja značilnost kadrovske strukture pripadnikov SV v tistem obdobju je predvsem psihološko nefiltrirana populacija tako stalnega sestava vojakov kot tudi nabornikov v SV. Poleg dejavnikov, ki so povezani s kadrovsko sliko SV v času veljavnosti naborniškega sistema, pa je strokovna komisija kot nekatere organizacijske dejavnike, ki so znatno vplivali na številčnost samomorov med vojaki SV, definirala predvsem lahek dostop do orožja. Iz analize izhaja, da je bilo 23,5 odstotka samomorov storjenih med stražarsko službo ali požarstvom. Komisija je tudi ocenila, da sta med socialnimi in psihološkimi vzgibi najpogostejša osamljenost in monotonost. Le 17,6 odstotka vseh evidentiranih samomorov med pripadniki SV je bilo storjenih v prostem času, in ne med službo (GŠSV, 2011, str. 7 in 9).

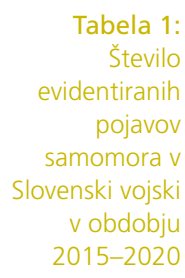

\begin{tabular}{|c|c|c|c|}
\hline Leto & $\begin{array}{c}\text { Število } \\
\text { samomorov }\end{array}$ & $\begin{array}{c}\text { Število } \\
\text { pripadnikov } \\
\text { SV }^{[1]}\end{array}$ & $\begin{array}{c}\text { Količnik } \\
\text { samomorilnosti na } \\
\mathbf{1 0 0 . 0 0 0} \text { prebivalcev }\end{array}$ \\
\hline $\mathbf{2 0 1 5}$ & 2 & 7009 & 28,5 \\
\hline $\mathbf{2 0 1 6}$ & 3 & 6875 & 43,6 \\
\hline $\mathbf{2 0 1 7}$ & 0 & 6777 & 0 \\
\hline $\mathbf{2 0 1 8}$ & 3 & 6640 & 45,1 \\
\hline $\mathbf{2 0 1 9}$ & 0 & 6402 & 0 \\
\hline $\mathbf{2 0 2 0}$ & 0 & 6321 & 0 \\
\hline Skupaj & $\mathbf{8}$ & & $\mathbf{1 9 , 5}$ \\
\hline Povprečje & $\mathbf{1 , 3}$ & $\mathbf{6 6 7 0}$ & \\
\hline
\end{tabular}

${ }^{[1]}$ Osnutek zakona o spremembah in dopolnitvah Zakona o obrambi, EVA 2020-1911-0009, stran 4

Podatki o gibanju primerov samomora med pripadniki SV v obdobju od leta 2015 do 2020 v tabeli 1 (GŠSV, 2021) kažejo, da je povprečno število samomorov v SV v omenjenih šestih letih 1,3 samomora na leto in da je povprečni količnik samomorilnosti v omenjenem obdobju 19,5 samomora na 100.000 prebivalcev. 


\section{SAMOMOR V SLOVENSKI POLICIJI - PODATKI ZA OBDOBJE OD LETA 2009 DO 2020}

Policija je že pred leti začela izvajati preventivne ukrepe, od vzpostavitve SOStelefona, zaposlitve psihologov na vsaki policijski upravi, organizacije mreže policijskih zaupnikov do začetka dela policijskega vikarja. Ukrepi policije so bili formalizirani v Pravilniku o psihološki pomoči in psihološki podpori uslužbencem policije (2013). Policiste s tovrstnimi težavami obravnava strokovna služba na MNZ, sestavljena iz psihologov in zdravstvenih delavcev, izvajajo pa se tudi terminski preventivni pregledi vseh policistov.

Podatki o samomorih v milici in policiji v obdobju od leta 1948 do 2016 so bili predstavljeni v Reviji za kriminalistiko in kriminologijo leta 2017 (Blažina, 2017, str. 338, 349). Ker za obdobje od leta 2017 naprej nismo pridobili uradnih podatkov o samomorih v slovenski policiji, nam je neuradne podatke, zbrane od svojih regionalnih predstavnikov, posredoval Sindikat policistov Slovenije (v nadaljevanju SPS). Ker gre za neuradne podatke, jih je treba povzemati in uporabljati previdno. Podatke za izračun količnikov samomorilnosti med policisti in količnike samomorilnosti med splošno populacijo smo poleg podatkov SPS (SPS, 2021) prevzeli tudi iz javno objavljenih podatkov Nacionalnega instituta za javno zdravje (NIJZ, 2017, 2018, 2020a in 2021), podatkov o številu policistov v obravnavanih letih - iz letnih poročil Policije, objavljenih na spletni strani Policije - statistika (razdelek letna poročila policije - število vseh policistov) (MNZ Policija, 2021) in znanstvenega članka, ki prikazuje gibanje in problematiko samomorov v Republiki Sloveniji od leta 1948 do 2016 (Blažina, 2017, str. 348-349).

V okviru prejetih podatkov o samomorih v policiji od leta 2017 do 2020 smo s pomočjo policijskega sindikata tokrat prvič zbrali tudi podatke o poskusih samomorov med policisti, pri čemer so v omenjenem obdobju poskušali storiti samomor štirje policisti. Od policistov, ki so od leta 2017 do 2020 izvršili samomor, sta po podatkih SPS vsaj dva policista predhodno že enkrat poskušala storiti samomor, vendar tudi po poskusu izvršitve kljub temu še naprej posedovala službeno orožje, s katerim sta samomor pozneje tudi dokončno izvršila (SPS, 2021).

Glede na obdobje povečanega količnika samomorilnosti med slovenskimi policisti v času od leta 2017 do 2020 pa kot način storitve samomora v sindikatu beležijo:

- dva samomora z obešanjem,

- pet samomorov s strelnim orožjem in dva poskusa storitve samomora,

- en samomor - skok z višine,

- en poskus samomora s hladnim orožjem,

- en poskus samomora - zastrupitev s tabletami.

Glede na podatke od leta 2009 do 2020 se v 11-letnem povprečju kaže pogostost samomorov v policiji predvsem v letih 2018, 2019 in 2020 (tabela 2). Zaradi 
omenjenega dejstva bomo v nadaljevanju še posebej pozorno analizirali podatke o samomorilnosti za zadnje triletno obdobje, od leta 2018 do 2020. Ugotovili smo namreč, da je v obdobju od leta 2017 do vključno 2020 samomor izvršilo skupno osem policistov - to je povprečno dva samomora na leto, štirje pa so poskusili storiti samomor. V obdobju od leta 2009 do 2016 je samomor naredilo skupaj deset policistov oziroma na leto povprečno 1,2 policista, podatkov o poskusih samomora v tem obdobju pa nimamo. Glede na ugotovljen desetletni trend konstantnega upadanja količnika samomorilnosti med slovensko splošno in moško populacijo v obdobju od leta 2009 do vključno 2019 (Roškar, 2020) smo glede na predstavljene podatke v policiji priča dvigu količnika v zadnjih enajstih letih (2009-2020) (graf 2) in predvsem opaznemu dvigu količnika v zadnjih štirih letih, od leta 2017 do 2020 (graf 1). Obenem v istem obdobju opažamo skoraj izenačenje enajstletnega (20092020) količnika samomorov v slovenski policiji $(20,4)$ in povprečnega količnika slovenske splošne populacije $(20,2)$. Količnik samomorilnosti med moško splošno populacijo $(31,8)$ je $\mathrm{v}$ obdobju od leta 2009 do 2020 znatno višji kot ta v policiji $(20,4)$.

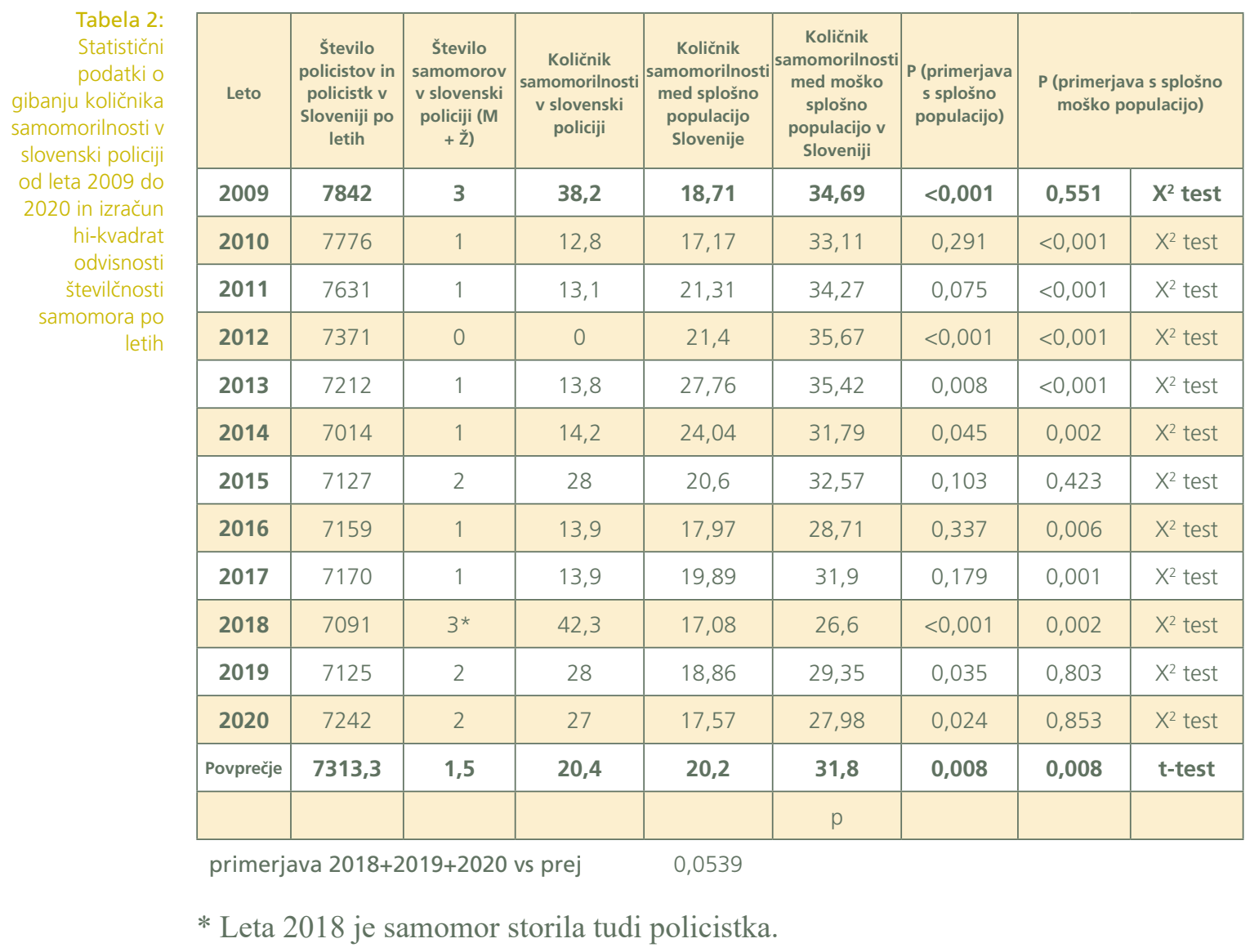


Graf 1:

Pregled

številčnosti

samomorov v

Slovenski vojski

in policiji v

obdobju od leta

2015 do 2020

\section{Linearni prikaz gibanja številčnosti samomorov v SV in Policiji (2015-2020)}

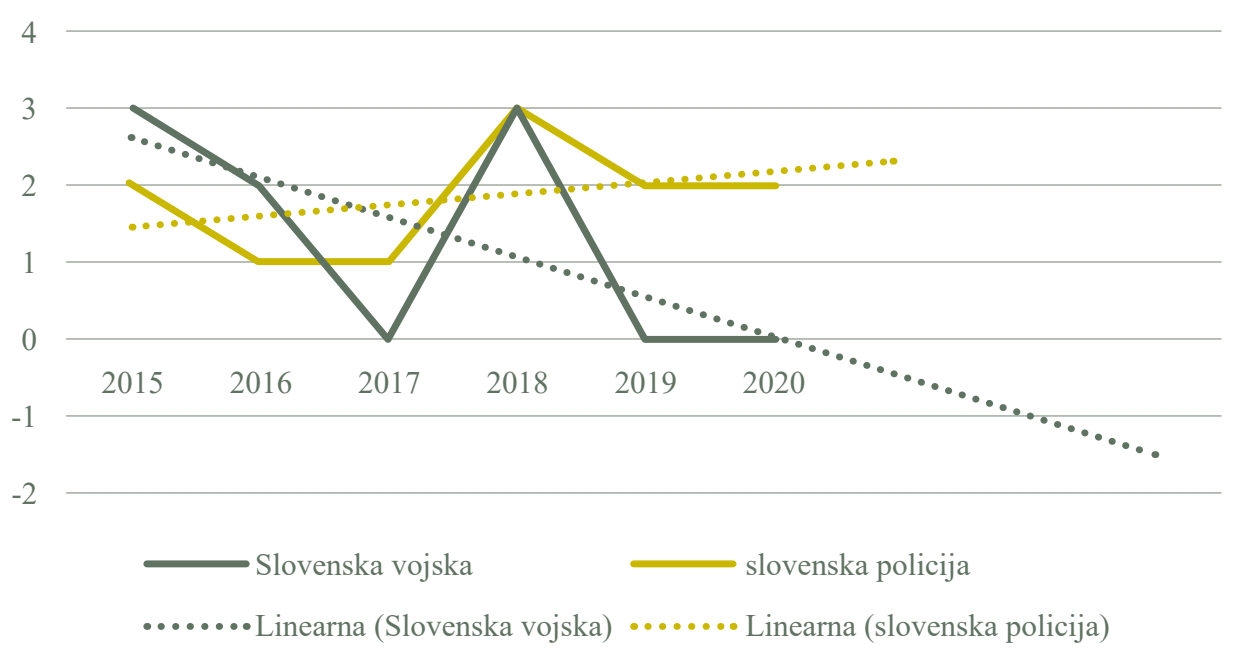

Statistika samomorov v slovenski policiji 2009-2020

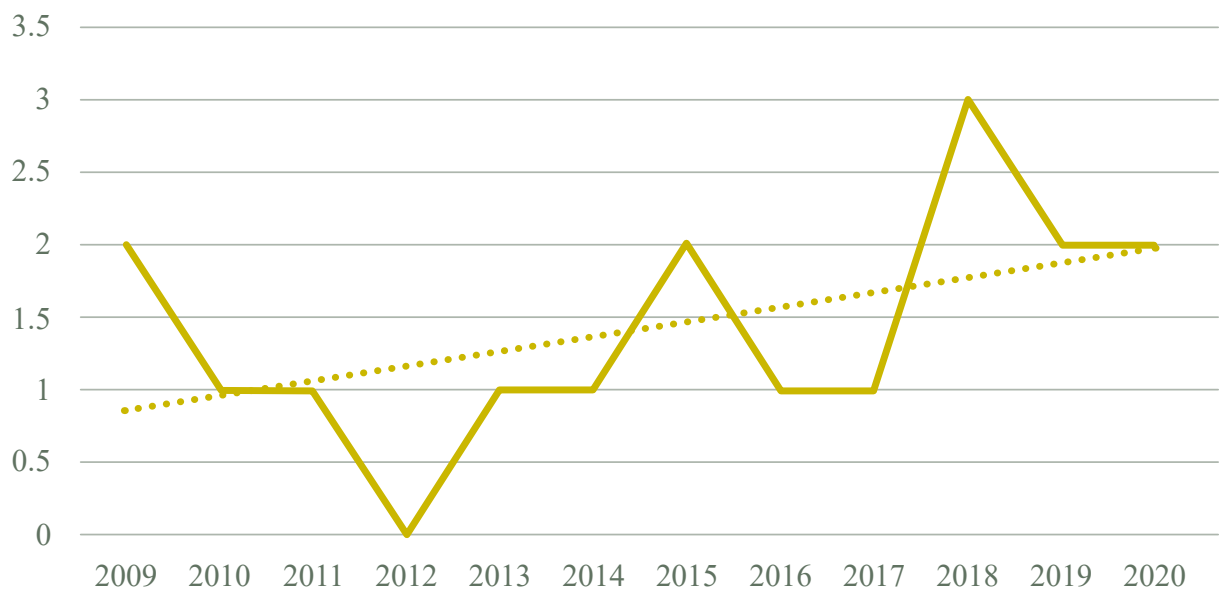

Za testiranje razlik (statistično značilne odvisnosti) v količniku samomorilnosti v policiji in med splošno populacijo za vsako koledarsko leto posebej smo uporabili 
statistično metodo hi-kvadrat test ${ }^{5}$. V tabeli 2 sta prikazana p-vrednost, ki se nanaša na primerjavo s splošno populacijo (predzadnji stolpec), in p-vrednost, ki se nanaša na primerjavo s splošno moško populacijo (zadnji stolpec). Ugotovimo, da je bil v primerjavi s splošno populacijo indeks samomorilnosti v policiji statistično značilno višji v letih 2009, 2014, 2018, 2019 in 2020, v letih 2012, 2016, 2017 pa statistično značilno nižji. V primerjavi s splošno moško populacijo je količnik samomorilnosti statistično značilno višji leta 2018, nižji pa v letih od 2010 do 2014, 2016 in 2017. Primerjava povprečnega količnika $\mathrm{v}$ policiji in splošni populaciji s t-testom za neodvisna vzorca ne pokaže statistično značilnih razlik $(\mathrm{p}=0,949)$. So pa te razlike statistično značilne, ko primerjamo količnik samomorilnosti pri policistih in $\mathrm{v}$ slovenski moški populaciji $(\mathrm{p}=0,008)$. Količnik samomorilnosti je v proučevanem obdobju v policiji statistično značilno nižji od tistega med moško splošno populacijo. Primerjava količnikov v letih 2018 in 2020 ter tistih v obdobju od leta 2009 do 2017 pokaže, da med časovnima obdobjema ni statistično značilnih razlik v količniku samomorilnosti $(p=0,0539)$, pri čemer lahko opazimo, da gre za minimalne mejne statistične vrednosti ${ }^{6}$. Glede na podatke, prikazane v grafu 2, lahko sklepamo, da se število samomorov v slovenski policiji v zadnjih enajstih letih (2009-2020) povečuje. Glede na raziskavo iz leta 2017, v kateri so analizirali gibanje samomorilnosti v policiji od leta 1995 do 2016 (Blažina, 2017, str. 349), je bilo takrat ugotovljeno, da je gibanje samomorov v tistem statističnem obdobju konstantno in se niti dviga niti ne pada. Leta 2017 smo s pomočjo SPS evidentirali le po en primer samomora in poskusa samomora policista, opazen pa je dvig števila samomorov v zadnjih treh letih oziroma od leta 2018 do 2020, ki je glede na prejšnje statistično obdobje, od leta 2009 do 2017, kljub vsemu le mejno statistično značilen oziroma za zadnje obdobje kljub vsemu še ne moremo govoriti o značilnem statističnem povečanju.

Podatki o vzročnosti samomorov v policiji za obdobje od leta 2017 naprej nam niso znani, saj niso dosegljivi.

Glede na način storitve samomora je od leta 2009 do 2016 od skupno 31 evidentiranih primerov prevladoval samomor z ustrelitvijo - 18 primerov ali $69,2 \%$, sledi samomor z obešanjem - trije primeri ali $11 \%$ ter zastrupitev s CO - dva primera ali 7 odstotkov (Blažina, 2017, str. 351). V obdobju od leta 2017 do 2020 prevladuje način storitve samomora z ustrelitvijo - pet primerov ali $62 \%$, dva samomora z obešanjem ali 25 $\%$, en samomor - skok z višine ali 12,5 \% (SPS, 2021). Za obravnavano skupno obdobje od leta 2009 do 2020 lahko ugotovimo, da je bilo za storitev samomora v $74,2 \%$ uporabljeno strelno orožje (23 primerov), v 16,1\% je bil samomor izveden z obešanjem (pet primerov), v 6,5 \% z zastrupitvijo s CO (dva primera) in v enem primeru (ali 3,2 \%) s skokom $\mathrm{z}$ višine. V statistiki nismo upoštevali poskusov samomora, ki smo jih zbrali le za obdobje od leta 2017 do 2020, in sicer sta bila dva poskusa samomora z ustrelitvijo, eden s hladnim orožjem in eden z zastrupitvijo $\mathrm{s}$

\footnotetext{
Hi-kvadrat ( $\chi 2$ ). Z navedeno statistično metodo smo ugotovili odvisnost ali neodvisnost (statistično odvisnost) različnih parametrov in kategorij primerjalnih skupin med seboj (statistično značilne razlike so podane, ko je rezultat p-vrednosti $<0,05)$.

${ }^{6}$ Statistično značilna vrednost je podana šele, ko je p-vrednost $<0,05$.
} 
tabletami. Glede na opisano lahko zaključimo, da v obdobju od leta 2009 do 2020 pričakovano prevladuje način storitve samomora z ustrelitvijo, skupaj 74,2 \%.

\section{UGOTOVITVE IN REZULTATI OPRAVLJENE RAZISKAVE}

$\mathrm{Na}$ podlagi opravljene analize statističnih podatkov smo ugotovili, da se statistika gibanja samomorov v policiji v obdobju od leta 2009 do 2020 postopoma povečuje (graf 2). Podatke o pojavnosti samomorov smo črpali iz že objavljene analize samomorilnosti v policiji od leta 2009 do 2016, v kateri so uporabljeni uradni podatki policije (Blažina, 2017). Ker ni na voljo uradnih podatkov, smo za izvedbo raziskave statistike in pojavnosti samomorilnosti v policiji uporabili in upoštevali tudi neuradne podatke Sindikata policistov Slovenije, in sicer za obdobje od leta 2017 do 2020. Podatki so predstavljeni v tabeli 2. Predvidevamo tudi, da se bo ob odsotnosti sprememb tak trend $\mathrm{v}$ prihodnosti še nadaljeval.

Ugotovili smo tudi, da je slovenska policija ustrezno sistemsko pripravljena na spoprijemanje s problematiko samomorilnosti v lastnih vrstah. Policistom so nenehno na voljo usposobljeni psihologi, ki so organizirani na policijskih upravah ali v posameznih večjih enotah, delujejo tudi SOS-telefon, mreža policijskih zaupnikov, vikar in predstavniki policijskih sindikatov. Posameznike, ki so samomorilno ogroženi, obravnava strokovna zdravstvena služba v okviru MNZ. Policija ima ukrepe strukturirane v lastnem Pravilniku o psihološki podpori uslužbencem policije (2013).

Ugotovili smo, da policija sistematično ne vodi podatkov o samomorih v lastni organizaciji in podatkov ne analizira, niti na tej podlagi ne izvaja ukrepov. Nekateri policisti, ki so samomorilno ogroženi in so že poskusili storiti samomor, lahko kljub temu še naprej posedujejo službeno orožje oziroma so s službenim orožjem samomor tudi dokončali.

Policija deloma upošteva domače in tuje aktualne smernice in ugotovitve, povezane s področjem samomorilnosti v policiji ali med splošno populacijo. Predvsem bi bilo smiselno upoštevati domače in tuje ugotovitve, povezane s povečano samomorilno ogroženostjo oseb, ki so že enkrat poskusile storiti samomor, in hkrati odtegniti sredstva, s katerimi bi samomor lahko izvedle oziroma ponovile (v tem primeru omejitev dostopa do službenega orožja). Prav tako bi bilo v luči Resolucije o nacionalnem programu duševnega zdravja 2018-2028 smiselno vzpostaviti evidenco samomorov v policiji, pripraviti lastni akcijski načrt ali pa vsaj izvajati terminske analize pojava samomorilnosti $\mathrm{v}$ policiji $\mathrm{z}$ določitvijo potrebnih preventivnih ukrepov in predvidenim gibanjem te problematike $\mathrm{v}$ prihodnosti.

Da bi preverili uspešnost in pripravljenost policije za spoprijemanje s problematiko samomorilnosti v lastnih vrstah, smo opravili tudi vzporedno raziskavo glede načina ukrepanja ob pojavu samomorilnosti v Slovenski vojski, vključno s primerjavo statističnih podatkov o številčnosti pojava samomorilnosti v obeh organizacijah. 
Ugotovili smo, da se Slovenska vojska s problematiko samomorov v svojih vrstah ukvarja sistemsko in na podlagi vnaprej predvidenih ukrepov, navedenih v posebnem akcijskem načrtu. Stanje na področju problematike samomorov se sproti spremlja, analizira in na tej podlagi se pripravljajo ustrezni ukrepi. Pričakovano je še nadaljnje upadanje števila samomorov v SV (graf 1).

Sklep Pri analizi stanja na področju samomorov v policiji smo ugotovili, da v splošni populaciji v Sloveniji količnik samomorilnosti rahlo upada, kar traja vse od osamosvojitve države. Enakemu trendu statistično sledi tudi količnik samomorilnosti v policiji. Zbrani podatki za obdobje od leta 2017 do 2020 (osem samomorov policistov in štirje poskusi), še posebej v letih od 2018 do 2020 (sedem samomorov, trije poskusi), pa kažejo na pogostejše primere samomorov v policiji. Pri zbiranju podatkov o številčnosti in okoliščinah storitve samomorov v policiji smo se že $\mathrm{v}$ uvodu srečali s težavo zaradi odsotnosti podatkov o samomorih v policiji. Policija in Ministrstvo za notranje zadeve jih ne zbirata in analizirata. Posledično se v policiji oziroma v zdravstveni službi ministrstva ${ }^{7}$ ukvarjajo $\mathrm{z}$ vsakim posamičnim primerom stiske policista posebej, podatkov pa statistično ne zbirajo in podatkov nimajo, kar izhaja iz odgovora Ministrstva za notranje zadeve (MNZ, 2019) in policije (MNZ Policija, 2019), ki samo povzema odgovor ministrstva. Oba dopisa smo prejeli v začetku priprav in zbiranja podatkov za izvedbo te analize. Kot razlog za odsotnost tovrstnih podatkov nam je ministrstvo $\mathrm{v}$ dveh ločenih odgovorih pojasnilo, da evidence samomorov $\mathrm{v}$ policiji na ministrstvu ne vodijo, podatki o samomorih $\mathrm{v}$ policiji pa niso del evidenc, ki jih ministrstvo vodi s področja kadrov, varstva pri delu in socialne varnosti (MNZ Policija, 2019). Ocenjujemo, da bi Ministrstvo za notranje zadeve ob upoštevanju 19. člena Zakona o varnosti in zdravju pri delu (ZVZD-1, 2011) že zdaj lahko izvajalo analitično dejavnost problematike, povezane s samomori v policiji, in sicer kot del celovite ocene tveganja. Pri tem bi bilo treba upoštevati omejitve, ki se nanašajo na varstvo osebnih podatkov v obravnavanih primerih, obenem pa je treba razumeti, da je zaradi majhnega števila primerov samomorov težko zagotoviti popolnoma anonimizirane podatke, ki bi bili pozneje predstavljeni v splošni in bolj poglobljeni analizi. Nasprotno prej opisanemu pa SV problematiko samomorilnosti v SV izvaja redno in sistematično, glede na vsebino lastnega akcijskega načrta, ki ima v prilogi navedene nosilce nalog, druge sodelujoče, naloge in konkretne roke izvedbe nalog (GŠSV, 2011). Podatke o samomorilnem vedenju vojakov črpajo iz zdravstvenih kartotek VZE (vojaških zdravstvenih enot) (GŠSV, 2011, str. 10).

Glede na ugotovljene vrzeli smo predlagali konkretne ukrepe, ki se smiselno nanašajo na Resolucijo o nacionalnem programu duševnega zdravja 2018-2028

MNZ za policijo izvaja kadrovske, finančne in logistične naloge podpore organa v sestavi, vključno z nalogami zdravja pri delu, kar je določeno v 3. členu Zakona o organiziranosti in delu v policiji (2013). 
(ReNPDZ18-28, 2018) $)^{8}$, ki bodo pomagali pri zmanjšanju in obvladovanju problema samomorilnosti v policiji ter bi obenem lahko postali primer dobre prakse obvladovanja in zmanjšanja samomorilnosti v varnostnih organih tudi v evropskem in svetovnem merilu. Predvsem gre za predlog za vzpostavitev tako imenovane evidence samomorov v slovenski policiji, doslednost pri omejevanju dostopa do orožja samomorilno ogroženim posameznikom, predvsem tistim, ki so samomor že poskušali storiti, ter pripravo in realizacijo terminsko omejenega operativnega načrta ukrepov. Posebno koordinacijsko telo v policiji bi na podlagi ustrezne pravne podlage lahko spremljalo gibanje samomorov ter izvajalo in vodstvu policije predlagalo učinkovitejše izvajanje preventivnih in kurativnih ukrepov za zaščito policistov. Pri primerjavi podatkov o številčnosti pojava samomorov med pripadniki SV in policije od leta 2015 do 2020 lahko ugotovimo, da sta obe populaciji približno enako ogroženi, primeri storitve samomorov pa niso konstantni, temveč se gibljejo od 0 do 3 primere na leto. Iz primerjave številčnosti storjenih samomorov v letih od 2015 do 2020 je razvidno, da je pri policiji trend pogostosti samomorov v vzponu, problematika izvršenih samomorov v SV pa se umirja in pada (graf 1). Vsekakor je pri omenjenem statističnem pregledu zaradi kratkega obdobja in majhnega števila evidentiranih primerov pri tolmačenju podatkov potrebna velika mera previdnosti, še posebej glede ocenjevanja prihodnjega gibanja te problematike $\mathrm{v}$ obeh populacijah. V obeh populacijah kot sredstvo izvršitve samomora prevladuje strelno orožje, obe populaciji pa sta glede številčnosti evidentiranih primerov izvršenih samomorov zelo blizu količniku samomorilnosti splošne populacije v Sloveniji.

Slovenska policija bi na podlagi uvedbe evidence samomorov, poglobljene analize vzročnosti in načrta izvedbe konkretnih ukrepov začela učinkoviteje izvajati preventivne ukrepe, pri tem pa obenem uskladila normativne vire, s katerimi bi predlagane nove ukrepe tudi formalno uredili. Pri tem bi kot primer dobre prakse lahko uporabila izsledke in akcijski načrt ukrepov, ki jih je glede zmanjšanja samomorilnosti med svojimi pripadniki že pripravila in jih tudi uspešno izvaja SV.

1. Barber, C., Berrigan, J. W., Sobelson-Henn, M., Myers, K., Staley, M., Azrael, D. et al., 2019. Analysis linking public safety and public health data for firearm suicide prevention in Utah. Health Affairs, 38(10), str. 1695-1701.

2. Blažina, B., 2017. The characteristics of suicide among Slovene police officers over the past seven decades. Revija za kriminalistiko in kriminologijo, 68(4), str. 333-358.

3. Costa, T., Passos, F., in Queirós, C., 2019. Suicides of male Portuguese police officers 10 years of national data. Crisis, 40(5), str. 360-364.

\footnotetext{
8 Strateški cilj Resolucije o nacionalnem programu duševnega zdravja 2018-2028 (ReNPDZ18-28, 2018) določa 15-odstotno zmanjšanje števila samomorov $v$ desetletnem obdobju kot prednostno področje preprečevanja samomora. Resolucija obenem določa potrebo po pripravi in sprejetju konkretnih podrejenih operativnih akcijskih načrtov ter specifične cilje: dvig ozaveščenosti in pismenosti na področju samomorilnosti, zgodnjo identifikacijo ogroženih oseb in zmanjševanje porabe alkohola, omejevanje sredstev za storitev samomora in zgodnjo identifikacijo ogroženih oseb. V pripravi je tudi triletni akcijski načrt za varovanje duševnega zdravja (NIJZ, 2020b), v katerem je kot prednostno področje definirano področje preprečevanje samomora.
} 
4. Grassi, C., Del Casale, A., Cucè, P., Kotzalidis, G. D., Pelliccione, A., Marconi, W. et al., 2019. Suicide among Italian police officers from 1995 to 2017. Rivista di Psichiatria 2019; 54(1), str. 18-23.

5. GŠSV, 2021. Podatki o spremljanju števila samomorov med pripadniki Slovenske vojske v obdobju 2015 do 2020, dopis št. 090-69/2021-3 z dne 30. 6. 2021.

6. GŠSV, 2011. Ukaz za implementacijo Akcijskega načrta za znižanje pogostosti pojavov samomorilnega vedenja v Slovenski vojski, št. 812-3/2011-410 z dne 14. 12. 2011.

7. GŠSV, 2011. Akcijski načrt za znižanje pogostosti pojavov samomorilnega vedenja na Ministrstvu za obrambo in v Slovenski vojski.

8. Huselja, A., 2017. Stres v uniformi. Ljubljana: Chiara.

9. Kolektivna pogodba za policiste, 2012. Uradni list RS (41/12, 97/12, 41/14 in 22/16).

10. Ministrstvo za notranje zadeve (MNZ), 2019. Dopis MNZ, številka 630-6/2019/3 (150212) z dne 7. 3. 2019. Ljubljana: Uprava za organizacijo in kadre.

11. Ministrstvo za notranje zadeve, Policija, 2021. Statistika: Poročila o delu policije za leta 2017-2020. https://www.policija.si/o-slovenski-policiji/statistika, 15. 6. 2021.

12. Ministrstvo za notranje zadeve, Policija, 2019. Samomori v slovenski policiji-odgovor. Dokument GPU PA, št. 630-40/2019/8 (262-02) z dne 17. 4. 2019.

13. Ministrstvo za obrambo, Slovenska vojska, 2021. Spremljanje števila samomorov med pripadniki SV v obdobju 2015 do 2020, dopis Sektorja za operativne zadeve Poveljstva sil SV, št. 090-69/2021-3 z dne 30. 6. 2021.

14. Nacionalni inštitut za javno zdravje (NIJZ), 2017. Zdravstveni statistični letopis 2017. https://www.nijz.si/sl/publikacije/zdravstveni-statisticni-letopis-slovenije-2017, 12. 5. 2021.

15. Nacionalni inštitut za javno zdravje (NIJZ), 2018. Zdravstveni statistični letopis 2018. https://www.nijz.si/sl/publikacije/zdravstveni-statisticni-letopis-2018, 10. 5. 2021.

16. Nacionalni inštitut za javno zdravje (NIJZ), 2020a. 10. september-Svetovni dan preprečevanja samomora. https://www.nijz.si/sl/10-september-svetovni-danpreprecevanja-samomora-preprecevanje-samomora-je-druzbena-naloga, 12. 5. 2021.

17. Nacionalni inštitut za javno zdravje (NIJZ), 2020b. Korak naprej v smeri večje dostopnosti storitev s področja duševnega zdravja: V Sloveniji trenutno v pripravi 3-letni akcijski načrt za varovanje duševnega zdravja. https://nijz.si/sl/korak-naprej-v-smerivecje-dostopnosti-storitev-s-podrocja-dusevnega-zdravja, 10. 5. 2021.

18. Nacionalni inštitut za javno zdravje (NIJZ), 2021. Svetovni dan preprečevanja samomora: Vletu 2020 blag upad števila samomorov. https://www.nijz.si/sl/svetovni-danpreprecevanja-samomora-v-letu-2020-blag-upad-stevila-samomorov, 15. 9. 2021.

19. Queirós, C., Passos, F., Bártolo, A., Marques, A. J., da Silva, C. F., Pereira, A., 2020. Burnout and stress measurement in police officers: Literature Review and a study with the operational police stress questionnaire. Frontiers of Psychology 11, str. 587.

20. Plemenitaš - Fuchs, N., 2003. Diplomsko delo Samomori v Slovenski vojski: Fakulteta za družbene vede. Ljubljana, http://dk.fdv.uni-lj.si/dela/Plemenitas-Fuchs-Natalija.PDF, 12. 5. 2021.

21. Pravila službe v Slovenski vojski, 2009. Uradni list RS, (84/09).

22. Pravilnik o psihološki pomoči in psihološki podpori uslužbencem policije, 2013. Uradni list $R S$, (51/13).

23. Resolucija o nacionalnem programu duševnega zdravja 2018-2028 (ReNPDZ18-28), 2018. Uradni list $R S$, (24/18).

24. Roškar, S., 2020. 10. september-Svetovni dan preprečevanja samomora. Preprečevanje samomora je družbena naloga. https://www.nijz.si/sl/10-september-svetovni-danpreprecevanja-samomora-preprecevanje-samomora-je-druzbena-naloga, 12. 5. 2021.

25. Sindikat policistov Slovenije (SPS), 2021. Podatki o samomorih v slovenski policiji, 12. 4. 2021. 
26. Violanti, J. M., Owens, S. L, McCaniles, E., Fekedulegn, D., Andrew, M. E., 2018. Law enforcement suicide: A review. Policing: An International Journal of Police Strategies \& Management, 42(2), str. 141-164.

27. Vlada RS, 2021. Duševno zdravje. https://www.gov.si/teme/dusevno-zdravje/, 21. 9. 2021.

28. Zakon o javnih uslužbencih (ZJU), 2007. Uradni list RS, (63/07, 65/08 in 69/08).

29. Zakon o organiziranosti in delu v policiji (ZDOPol), 2013. Uradni list RS, (15/13).

30. Zakon o spremembah in dopolnitvah zakona o obrambi, EVA 2020-1911-0009, str. 4, file:///C:/Users/brblazina/Downloads/o_ZObrOsn19062020\%20(3).pdf, 19. 6. 2021.

31. Zakon o službi v Slovenski vojski (ZSSloV), 2007. Uradni list RS, (68/07, 58/08).

32. Zakon o varnosti in zdravju pri delu (ZVZD-1), 2011. Uradni list RS, (43/11). 


\section{JAVNO MNENJE O TERITORIALNI OBRAMBI POLJSKE}

Povzetek Vojaški urad za družbene raziskave Vojaškega centra za državljansko vzgojo, ki se ukvarja z družbenimi raziskavami v vojaškem okolju, med drugim proučuje tudi delovanje in dejavnosti Teritorialne obrambe Poljske ter vedenje njenih pripadnikov. Poljake so vprašali, ali menijo, da bi morale biti naloge te nove formacije predvsem pomoč pri obvladovanju posledic naravnih in drugih nesreč, obramba lokalnega prebivalstva in infrastrukture ali druge oblike vojaškega delovanja. Teritorialna obramba je sodelovala tudi pri obvladovanju posledic pandemije na Poljskem. Glavni cilj članka je predstaviti veliko poljsko raziskavo na temo Teritorialne obrambe Poljske.

Ključne Teritorialna obramba, družbene raziskave, družbena percepcija, SARS-CoV 2, besede krizno upravljanje.

Abstract The functioning and activities of the Territorial Defence Forces and the behaviour of its soldiers are among the many interests of the Military Office of Social Research in the Military Centre for Civic Education, which conducts social research in the military environment. Poles were asked if they believed that the tasks of this new formation should primarily be assistance in actions to combat the effects of natural and other disasters, defence of local people and infrastructure, or other military operations. The Territorial Defence Forces engaged in the fight against the consequences of the pandemic in Poland. The main goal of this article is to present the major Polish research dedicated to the Polish Territorial Defence Forces.

Key words Territorial Defence Forces, social research, social perception, SARS-CoV 2, crisis management. 
Introduction The Territorial Defence Forces (TDF) were formed on January 1, 2017, and are the fifth type of armed forces in Poland. The Command of the Territorial Defence Forces took over, and cultivates the heritage of, the tradition of the Home Army Headquarters (1942-1945). In addition to defence activities, the purpose of this formation is the implementation of tasks in the field of crisis management, combating natural disasters and eliminating their effects, and protecting property, as well as search and rescue operations.

Military human resources play pivotal and crucial roles around the world. Not only do they work for security, but they also serve society. The Military Office of Social Research (MOoSR) conducts research into the activities of all the Polish Armed Forces, based on specific methodology and statistical samples. In this article we present an analysis of the opinions and assessment of the Territorial Defence Forces by Polish professional soldiers and employees of the Ministry of National Defence. Additionally, the authors included some social research about the TDF which was carried out by the Public Opinion Research Centre and ARC The Market and Opinion.

Finally, we added information about the »Immune Spring 2020« operation. The Polish Armed Forces carry out numerous military operations, but this particular one is aimed not only at all the infected people, but also at all the potential victims of Covid-19. The Minister of National Defence resolved to include the Polish Armed Forces in the fight against this invisible enemy (Hac, 2020).

The main goal of the article is to present research conducted by the Military Office of Social Research (MOoSR) and other research institutions.

\section{RESEARCH METHODS}

The research was conducted among two groups of respondents. The target group was Territorial Military Service (TMS) soldiers who have an account on the Territorial Defence Forces Information Portal (almost every TMS soldier has one) (Predel G., Iwanek M., 2019). A purposive sample of professional soldiers was composed of respondents participating in military training together with the surveyed reserve soldiers. The field research was carried out with the use of quantitative methods, using a mainly anonymous auditorium questionnaire. Only the examination of the TMS soldiers was carried out using a different technique (anonymous internet survey), because the Territorial Defence Forces Command decided that this was a better solution, due to the specificity of the service of these soldiers (limited number of training days and their high intensity). The questionnaires included substantive questions (closed and open) and socio-demographic questions characterizing the respondents.

The study was carried out with the use of the MOoSR research panel, which has a constant number of about 4,000 respondents (Iwanek M., Kiciński Ł., 2021). It was attended by soldiers carrying out professional military service in the Polish 
Armed Forces. It was a simple representative random sample, due to the fact that the respondents belonged to the corps of professional staff. The study was quantitative - a self-completion questionnaire was used. Out of 3,364 questionnaires sent, 1,724 correctly completed questionnaires qualified for the analysis, which constitutes about a $51 \%$ return rate. Taking into account the assumptions of the research panel, the presented results can be considered representative for the population of professional soldiers in the Polish Army.

CBOS (Centrum Badania Opinii Społecznej - The Public Opinion Research Centre) carried out the survey in 2017 in a representative random-quota sample of adult Poles with a two-fold over-representation in the provinces of Mazowieckie and Warmińsko-Mazurskie, and a three-fold over-representation in the provinces of Lubelskie, Podkarpackie and Podlaskie (the first TDF brigades were created in these provinces). The research sample comprised 1,502 people and the survey was carried out using the computer-assisted interview method (CAPI).

The research project »The Image of the Polish Army« was carried out in October 2019. This survey was conducted by ARC Rynek i Opinia (ARC The Market and Opinion, 2019) on a representative sample of the population of Poles aged 15 and older $(\mathrm{N}=1009)$ with overrepresentation added - 100 people aged 15-30, because people of this age are important to the army. So, in the end, there were 1,009 adults and 368 young people in the sample in the research project »The Image of the Polish Army«. The sample was representative in terms of gender, age, education and place of residence. This study was also conducted using the CAPI method.

Finally an analysis of literature focused on the Territorial services was carried out. Only those articles in which the author could refer to the theoretical and their own research conclusions and practical implementation for military human resources in the Polish Armed Forces and other military forces in the world were taken into account.

\section{RESEARCH INTO THE TERRITORIAL DEFENCE FORCES 2017-2020}

\subsection{Basic training of TMS soldiers in TDF structures}

Since the formation of the Territorial Defence Forces in 2017, they have been in the field of research interests of the Military Office of Social Research, operating as an internal unit of the Military Centre for Civic Education, which has been conducting social research in the military environment for the Ministry of National Defence for years, operating in the area of processes and social problems important to Poland's defence and security. During the period 2018-2020, two research projects were carried out to assess selected aspects of military service in the TDF. 
In 2018 soldiers of the Territorial Military Service, who are not professional soldiers but volunteers who perform rotational service (during military exercises and training) and are available at other times (called up when needed), were surveyed.

Most of the surveyed TMS soldiers underwent basic training in the stationary course, more than half of whom had already done it as part of their initial training in the TDF (16 training days in one block). The remaining respondents had undergone training previously as part of a different type of service (e.g. basic or candidate). Weekend training as part of the Territorial Defence Forces applied to only one in 20 TMS soldiers (Figure 1).

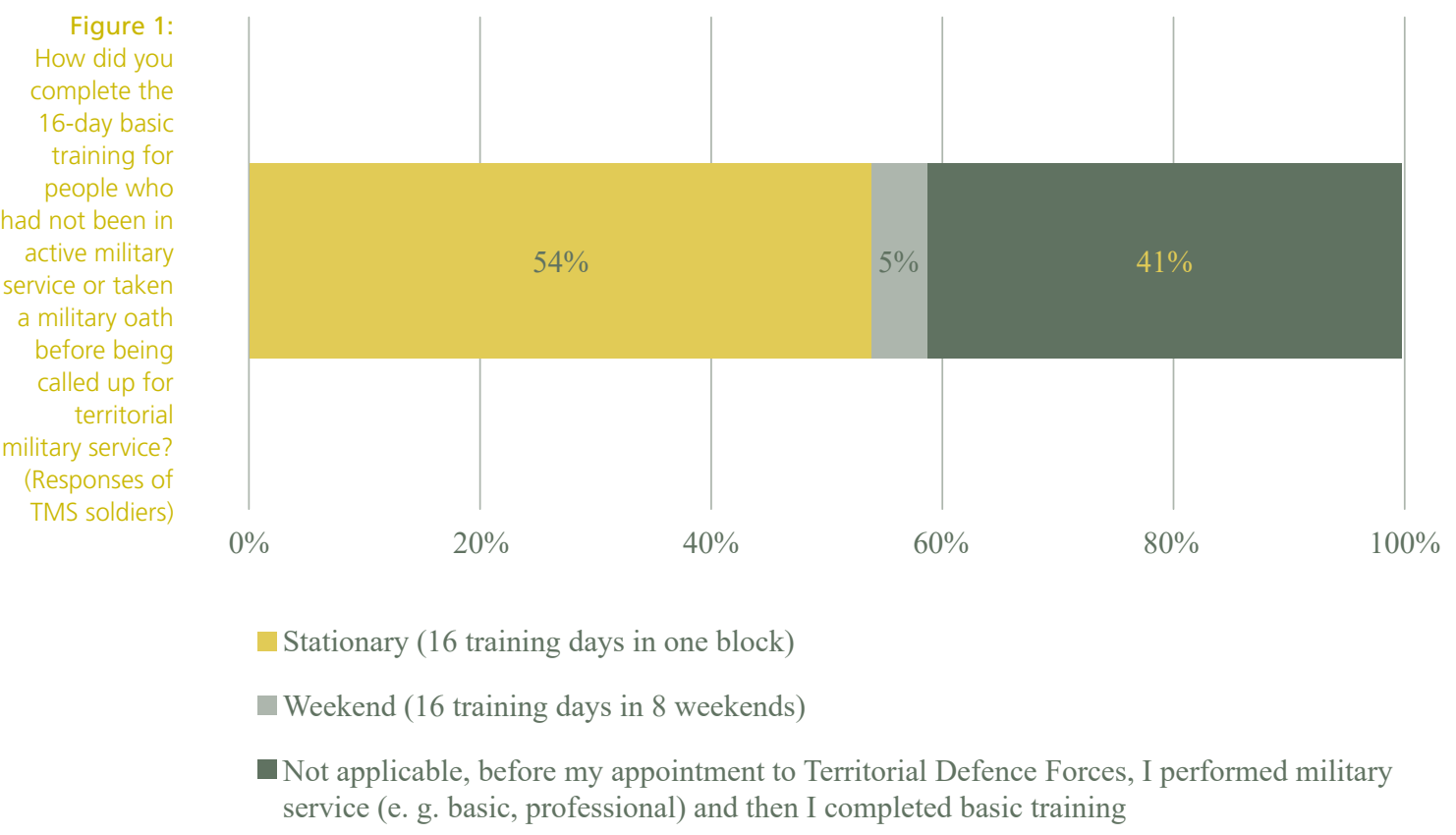

Figure 1: How did you complete the 16-day basic training for people who had not been in active military service or taken a military oath before being called up for territorial military service? (Responses of TMS soldiers)

The TMS soldiers assessed most aspects of the training very positively. The social and living conditions during the training, the planning and organizing of classes, and the material, equipment and teaching aids were rated slightly worse (Figure 2). 
Figure 2: How would you rate the

following aspects of the basic training you participated in? (Responses of TMS soldiers who underwent basic training within the Territorial

Defence Forces: $\mathrm{N}=210$ )

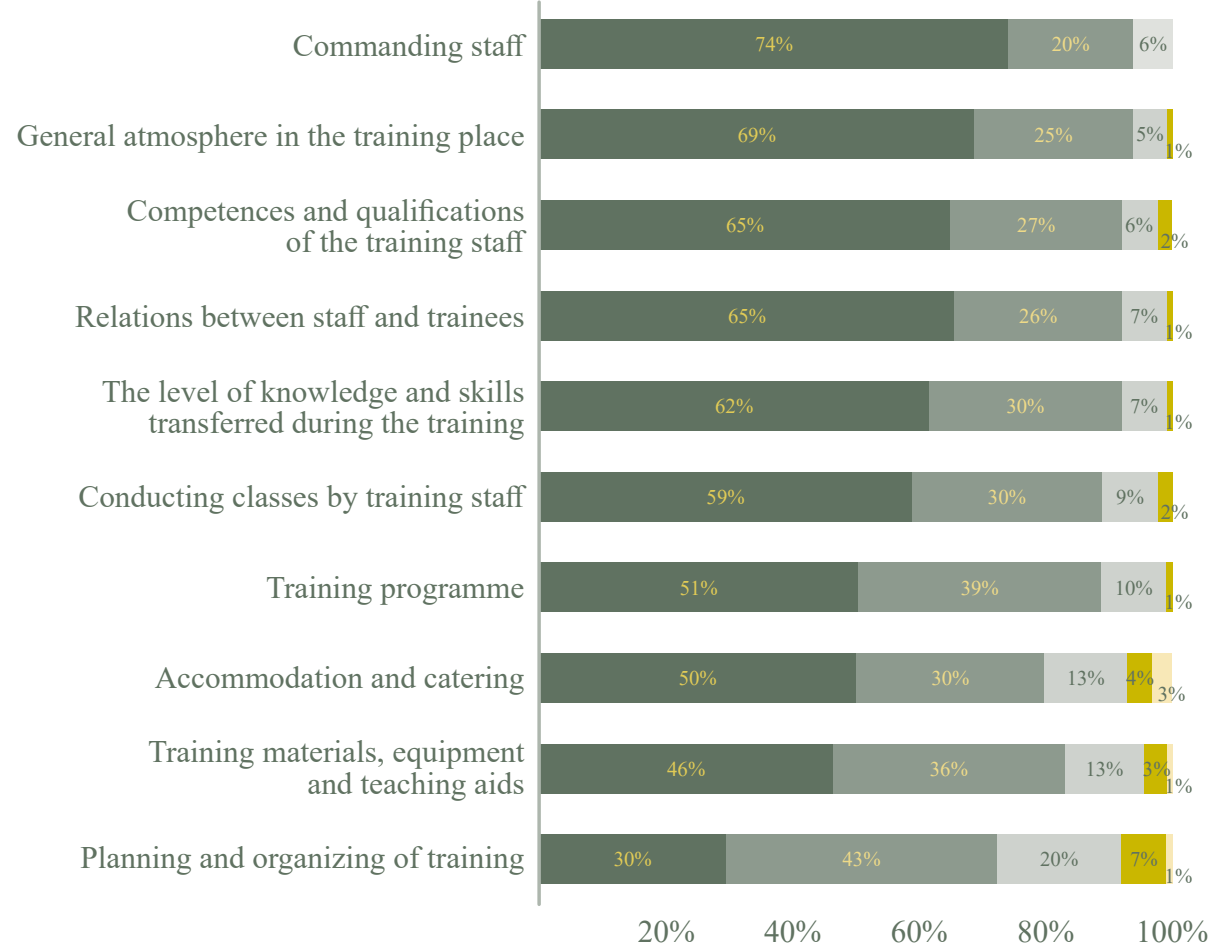

Very good Good Niether good, nor bad $\quad$ Bad Very bad

The basic training programme was rated on a scale from 1 to $5^{1}$, with 1 meaning No and 5, Yes. Between these other values of the interval scale are marked with numbers $2,3,4$. The respondents indicated the number that best reflected their opinion on a given element of the training. The values 1 and 2 were associated with more negative values, while 4 and 5 are associated with positive assessments. Choosing the value in the middle of the scale, 3 , was neutral.

Overall, the training programme was assessed positively. The TMS soldiers confirmed that it was interesting and modern, with the right amount of theory, and it developed their knowledge and skills. Other aspects, including the completeness of the programme, the correct ratio between the volume of the material and the training time, the possibility of showing one's own initiative, and the amount of practical

\footnotetext{
The scale used by the authors of the study was based on the Charles E. Osgood semantic differential method, but for technical reasons (the limited way of presenting questions in MS Forms), the scales were adapted in such a way that the respondent for a given scale had to assess whether their opinion was closer to grade »1 " or $» 2$ « (assigned as »No« answers), or to a »4« or »5 « rating (assigned as »Yes« ratings). Marking the number 3 meant that both answers were equally close to the respondent.
} 
training were assessed slightly worse. There were between 13 and 17 percentage points of negative ratings (Figure 3).

Figure 3:

How do

you rate the

basic training

programme?

who received

basic training

Territorial

Defence Forces; $\mathrm{N}=210$ )
(Responses of

TMS soldiers

under the

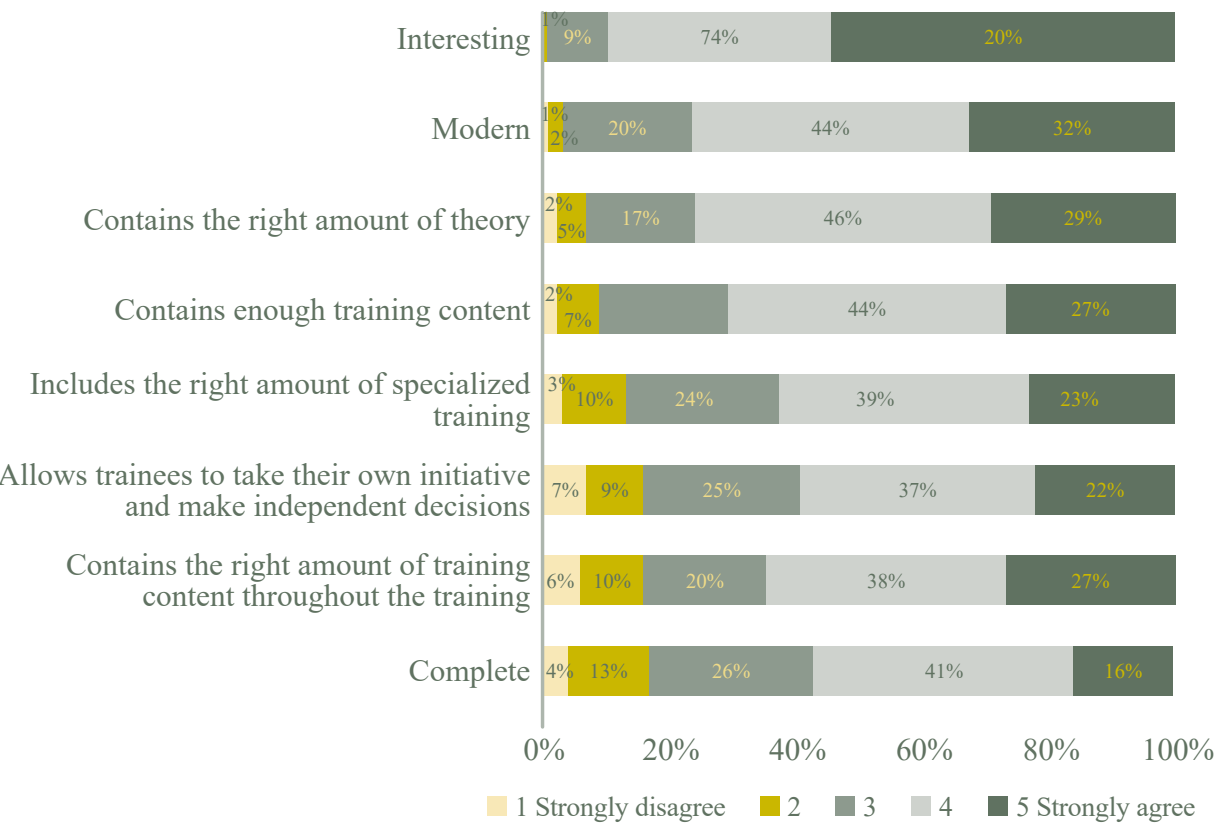

\subsection{Attitude of professional soldiers of operational forces to the Territorial} Defence Forces

According to the majority of the surveyed TMS soldiers, the basic training provided under the Territorial Defence Forces prepared them well for performing their official tasks. Only one in 10 soldiers were of the opposite opinion (mainly due to the short training time and insufficient number of practical classes) (Figure 4).

Figure 4:

Generally speaking, do you think that

basic training prepares you well for your job? (Responses of TMS soldiers who received basic training under the Territorial

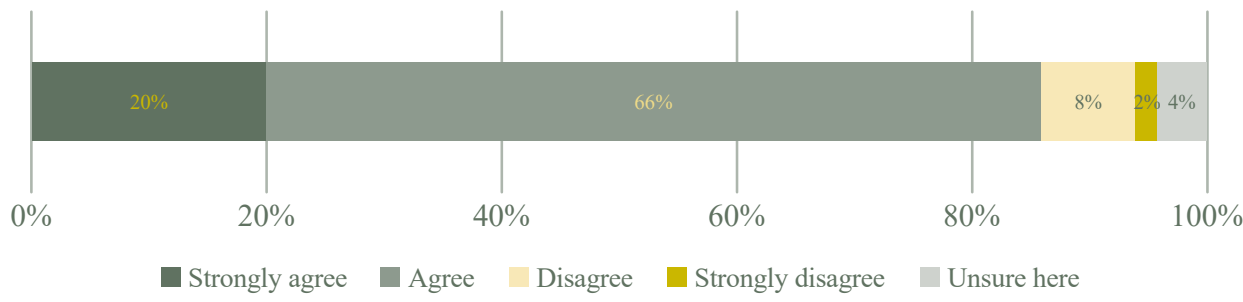

Defence Forces: $\mathrm{N}=210$ ) 
In 2020 the Military Office of Social Research researched the attitude of selected circles of the Polish Army to the Territorial Defence Forces.

More than half of the surveyed soldiers of operational troops positively assessed the concept and functioning of the TDF, and about one in 6 were of the opposite opinion. However, it should be noted that about one third (1/3) of the respondents did not have a specific opinion on this subject (Figure 5).

Figure 5: How do you generally evaluate the Territorial Defence Forces in terms of concept and functioning?

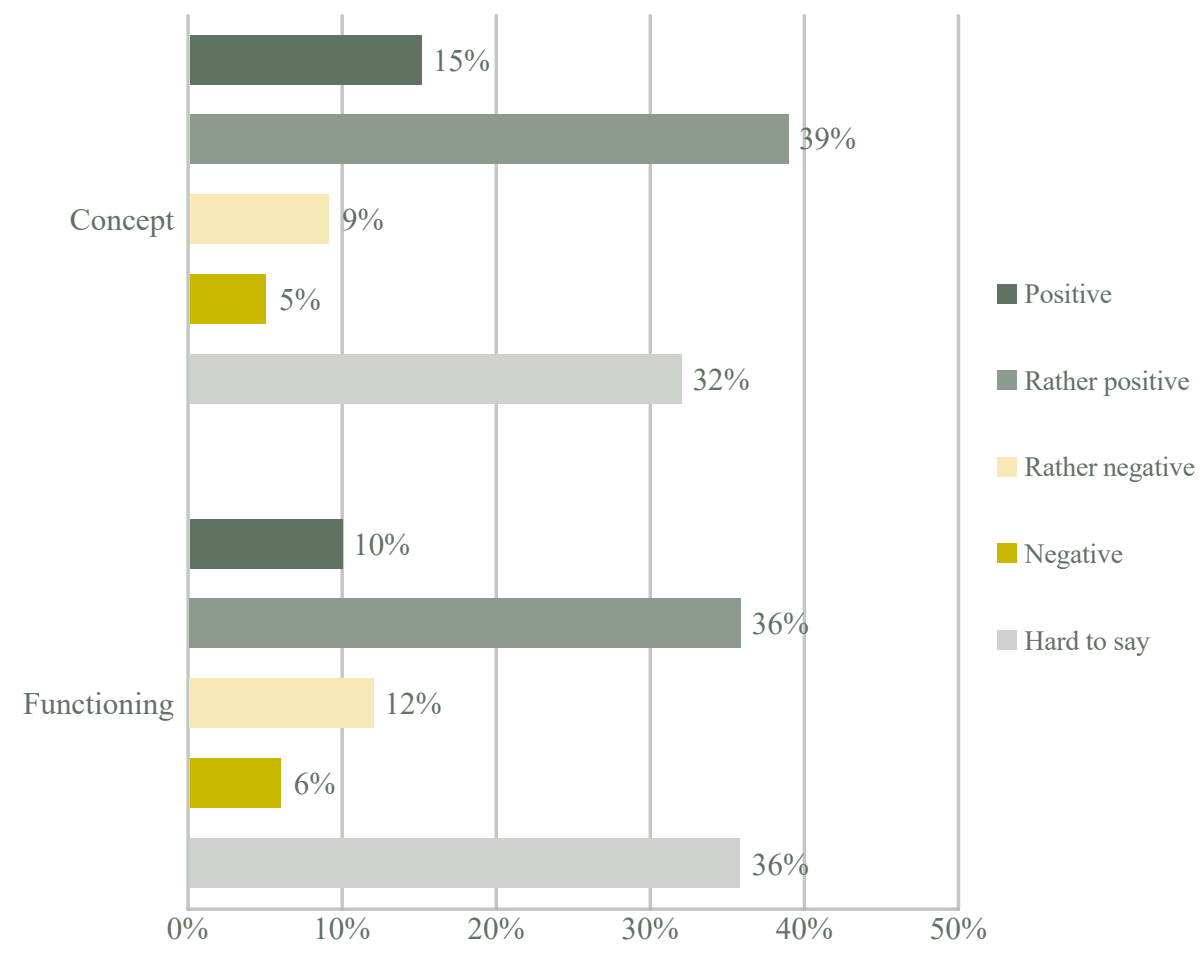

The soldiers of the operational troops justified their opinions in open statements.

In the positive aspects of the TDF they included:

- The TDF's support for operational units and relieving them of participation in crisis tasks;

- The TMS soldiers come from the area of TDF unit's location. 
Among the negative aspects were:

- The financing of the TDF, which takes money from the other military units;

- Lower level of training of TDF soldiers than other soldiers in the Polish Army (Table 1).

Table 1: Positive and negative aspects of the TDF's existence

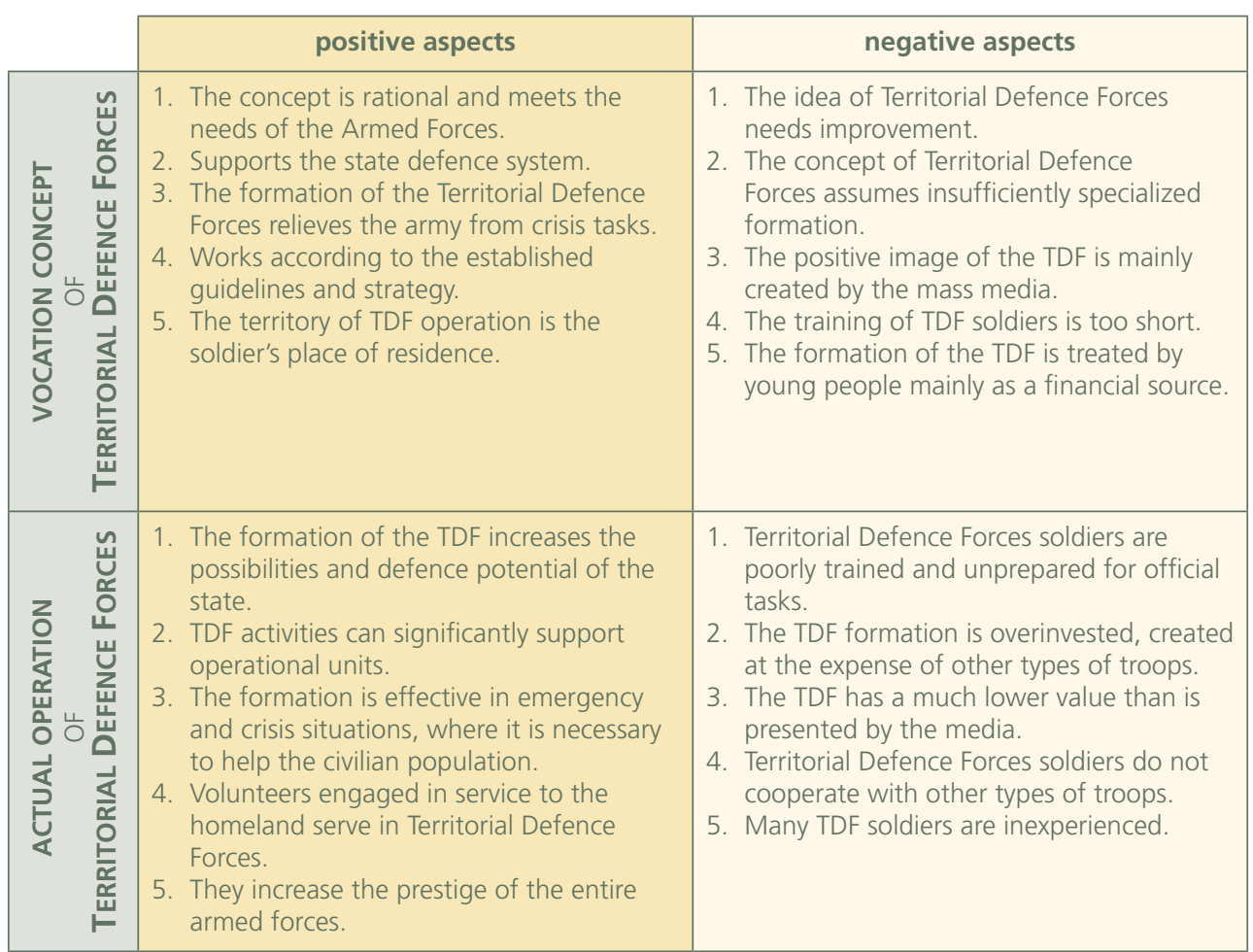

\subsection{Opinions of the TDF from selected military environments}

Since the formation of the Territorial Defence Forces, the Military Office of Social Research has found a gradual decline in the support of professional soldiers for the TDF. In 2017-2018 this trend led to there being more opponents than supporters of the TDF among professional soldiers (Figure 6). This was determined by the type of service; regular service soldiers more often supported the formation of the TDF than contract service soldiers. 
Figure 6:

Do you support

the formation

of the Territorial

Defence Forces?

(Comparison

of soldiers'

responses in

2017-2018,

data in \%)

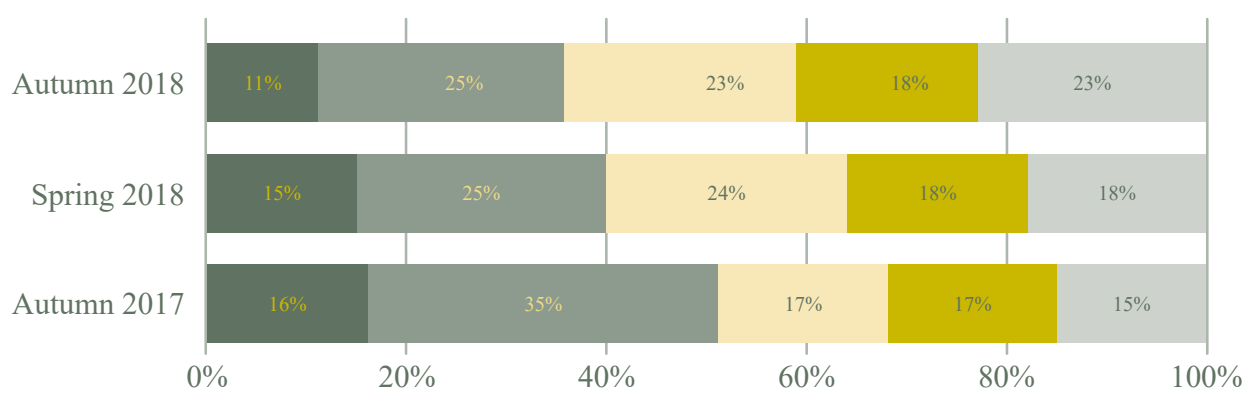

Definitely yes $\square$ Rather yes Neither agree nor disagree $\square$ Rather no Definitely no

Employees of the Ministry of National Defence of Poland were also asked for their opinion on the formation of the TDF. They are very divided in their opinions. More than a third of them supported this formation and the same number were against it, while over a quarter had no opinion (Figure 7).

Figure 7:

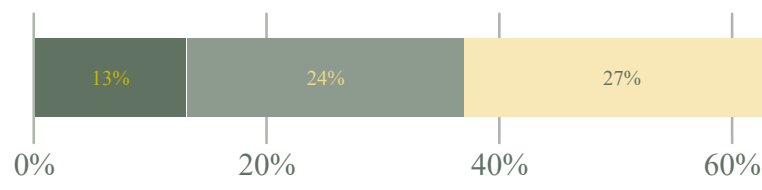

Definitely yes

Rather yes

Neither agree nor disagree

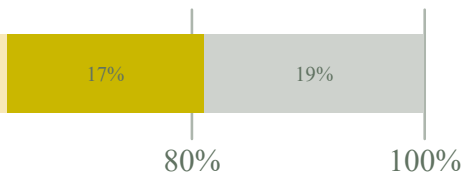

Rather no Definitely no

Figure 8: Do you support the formation of the Territorial Defence Forces?

(Cadets' responses)
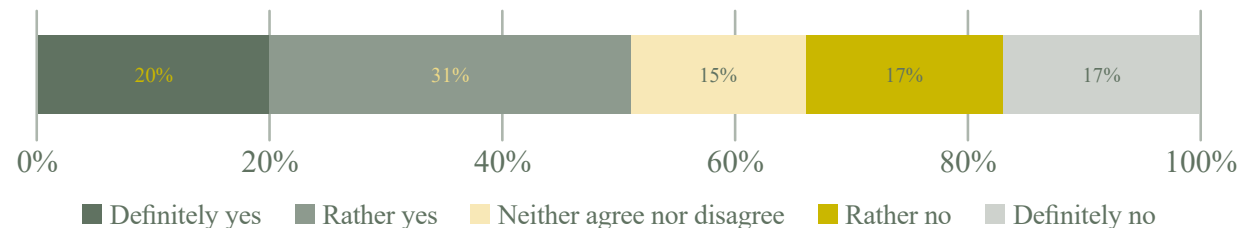


\subsection{The opinion of Poles on the Territorial Defence Forces}

In 2017 and 2019, the Military Office for Social Research developed two research projects concerning, among others, the Territorial Defence Forces (TDF).

The year 2017 was when this formation began to be set up in Poland. The Ministry of National Defence wanted to know whether Polish society supported the TDF building programme. The CBOS (Centrum Badania Opinii Społecznej - the Public Opinion Research Centre - research report), on behalf of the Military Centre for Civic Education, carried out the survey on a representative random quota sample of adult Poles with a two-fold over-representation in the provinces of Mazowieckie and Warmińsko-Mazurskie, and a three-fold over-representation in the following provinces of Lubelskie, Podkarpackie and Podlaskie. The first TDF brigades were created in these provinces. The research sample comprised 1,502 people and the survey was carried out using the computer-assisted interview method (CAPI).

The participants were asked if they had heard about the creation of the TDF, and $64 \%$ confirmed they had. The respondents were also asked the question: Do you personally support the creation of the Territorial Defence Forces or are you against it? The creation of the Territorial Defence Forces was supported by most of the respondents (Figure 9).

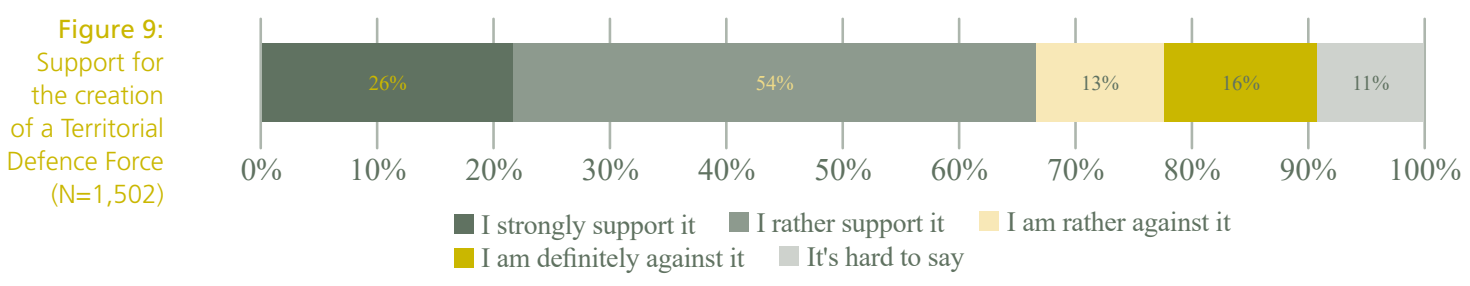

The participants were also asked if the creation of a territorial defence formation in Poland was appropriate, regardless of which party was in power in the country. Most of the respondents agreed with this (Figure 10).

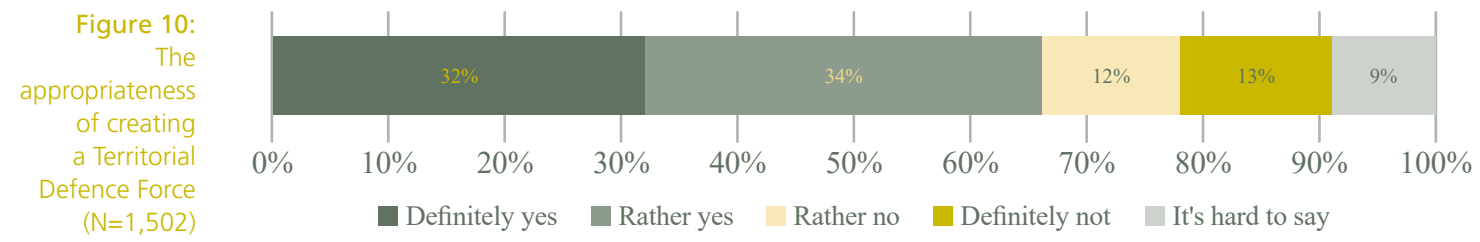


We were also interested in what the TDF's functions should be, according to the respondents. So we asked them: Regardless of your assessment of the Territorial Defence Forces, what tasks do you think they should perform? Most of the respondents' answers were positive with regard to:

The first task (in terms of choice) - Assistance in actions to combat the effects of natural and other disasters - 94\% endorsement;

The second task - Preparing areas and local infrastructure for emergencies in peacetime $-86 \%$;

The third task - Defence of the local people and local infrastructure in the event of a military conflict $-85 \%$.

Fewer of them thought that the tasks of the TDF should include: Military actions carried out jointly with a regular army in the event of a military conflict $-74 \%$. The least support was given to - Patriotic education, the spread of patriotic attitudes in society $-65 \%$. The detailed data are presented in Figure 11.

Assistance in the actions to combat the effects of catastrophes and natural disasters

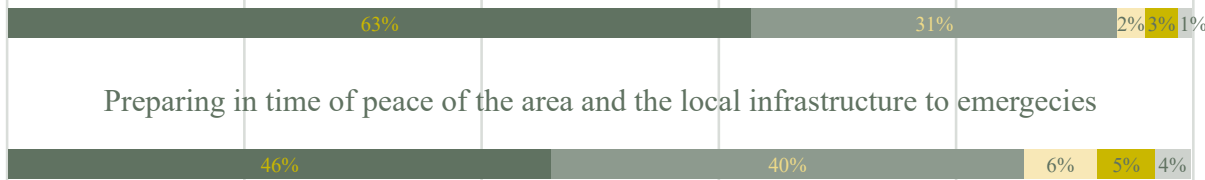

Defence of the local people and local infrastructure in the event of a military conflict

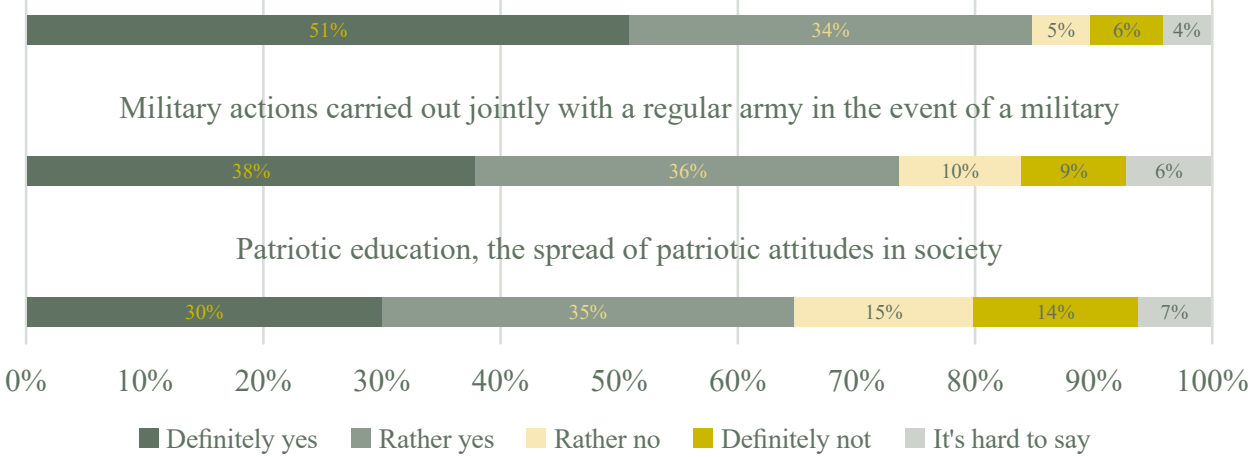

On the other hand, the majority of the participants believed that only professional soldiers can successfully defend the homeland. The question was: Today's methods of warfare require specialized knowledge, so the country's security can only be ensured 
by highly trained professional soldiers. The distribution of responses is shown in Figure 12.

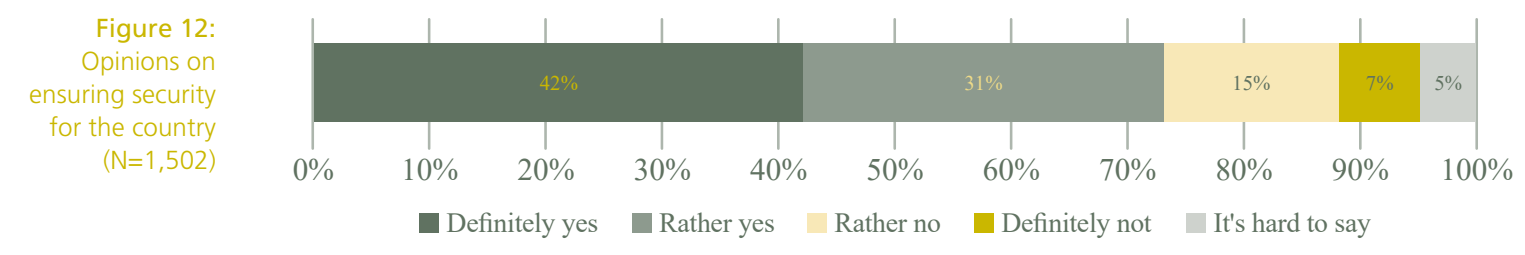

One very important consideration for the future of a new military formation is whether there are people willing to join. The respondents were asked the question: Service in the Territorial Defence Forces will be voluntary and will be paid. If you had the opportunity to join this formation, would you choose to do so? Near half of the adult Poles were definitely not interested in this and only $12 \%$ would certainly want to (Figure 13).

Figure 13:

Willingness

to join the

Territorial

Defence Forces

$(\mathrm{N}=1,502)$
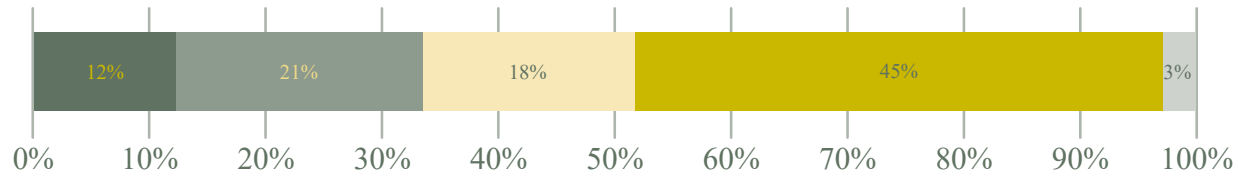

I would go for sure It is rather unlikely It's hard to say
I do not rule out such a decision

I'm deefinitely not interested

In October 2019, the research project »The Image of the Polish Army «, commissioned by the Ministry of National Defence, was carried out. The survey was conducted by ARC Rynek i Opinia (ARC The Market and Opinion - Report, 2019) on a representative sample of the population of Poles aged 15 and older $(\mathrm{N}=1,009)$ with overrepresentation added - 100 extra people aged 15-30, because people of this age are important to the army. So, in the end, there were 1,009 adult people and 368 young people from both representative samples. The samples were representative in terms of gender, age, education and place of residence. The study was conducted using the CAPI method.

We wanted to investigate what people know about the types of armed forces. It was an open question: What are the main types of troops in the Armed Forces of the Republic of Poland? The Territorial Defence Forces was mentioned by $28 \%$ of adult Poles and $25 \%$ of young people. In comparison, Land Forces were indicated by 
$82 \%$ of adults and $77 \%$ of young people; the Air Force by $76 \%$ of adults and $70 \%$ of young people; and the Navy by $71 \%$ of adults and $67 \%$ of young people. The other formations were less well known.

Aided knowledge of the various forms of military service was better. The respondents were asked: Which of these various possible forms of military service/military training have you heard of? As many as $73 \%$ of adults and $68 \%$ of young people had heard of the Territorial Defence Forces. In comparison, 94\% of adults and $91 \%$ of young people had heard of professional military service, and $76 \%$ of adults and $72 \%$ of young people had heard of studies at a military academy.

We also asked: Which of these various possible forms of military service/military training would you be interested in? Only 5\% of adults and 7\% of young people were interested in serving in the TDF; in comparison, $6 \%$ of adults and $10 \%$ of young people were interested in professional military service. These data are presented in Figure 14.

Figure 14:

Recognition of and interest in the Territorial Defence Forces $(\mathrm{N}=1,009)$

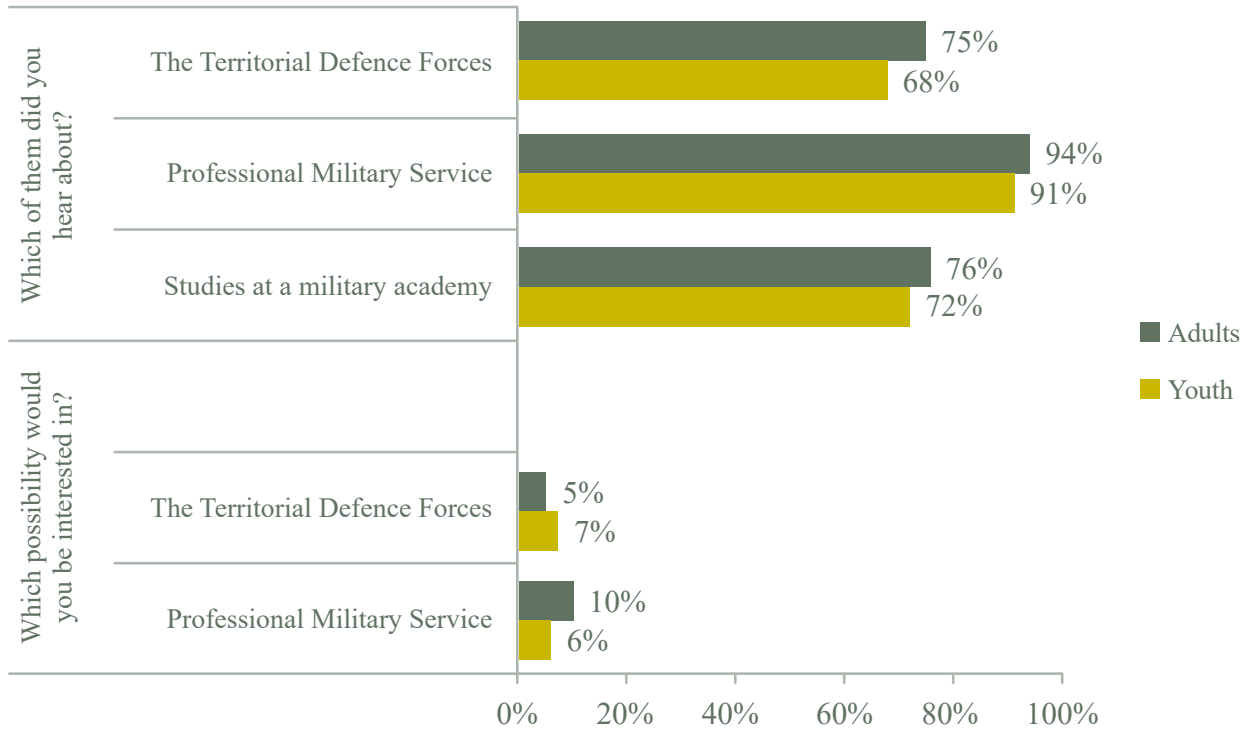

As we can see, many people are interested in joining the Territorial Defence Forces.

\subsection{The pandemic as a challenge to the Polish Armed Forces}

Today, both leaders and soldiers seem to be flexible and well-qualified enough to cope with the symptoms, range and outcome of a pandemic (Horyń, 2019). 
Military human resources and crisis management cooperate and merge with such groups of society as doctors, nurses, qualified rescuers and other medical forces. Both military human resources and crisis management are regarded as defensive resources to play a top-mind role in a potential occurrence of biological invasions (Jakubczak, Marczak, 1998).

Odporna wiosna (»Immune Spring«) was a military operation of Territorial Defence Forces units involving 2,500 soldiers. Below, we present the crucial links between the military, social and medical standpoints.

From the military point of view, the soldiers of Territorial Defence Forces were involved in:

- Support of the Polish police, Polish Border Guards, and regional and local government officers in preventing the spread of the SARS-CoV-2 virus, and support to infected people who were in quarantine.

- Limiting the danger of transmitting Covid-19 to members of the soldiers' families;

- Personnel and environmental education in the area of prevention and limiting infection (Kukuła, 2020).

From the social point of view, these soldiers supported the Polish people in many cases during the pandemic by:

- Carrying out an information campaign, i.e. distributing handouts;

- Encouraging social resistance by information and communication (Kukuła, 2020, Gąsiorek, Marek, 2020).

The »Territorials « activated a hotline for anyone who needed psychological support. They gave knowledge and guidance to those who feared being infected or isolated, and advised on how to cope with family members who were infected. They took care of Polish people who felt helpless and had strong feelings about the necessity of protecting their health.

From the medical point of view, the »Territorials « assisted the hospital and sanitary service by:

- Building field admission rooms for hospitals, which are still in operation;

- Providing personnel for the health service, especially in temporary hospitals;

- Supporting medical personnel's families and running a kindergarten for their children;

- Taking temperatures at the entrance to medical, civil and military facilities;

- Taking swabs at the state border and in other specially appointed facilities;

- Transporting infected patients from overcrowded hospitals to less-crowded ones;

- Organizing blood donation facilities in mobile stations in front of the National Defence Ministry and in other places (Gąsiorek, Marek, 2020). 
They evacuated old people from social welfare homes into temporary accommodation, and supported veterans, providing them with shopping and other essential items.

\subsection{The specific character of the "Territorials", or diversity management in the Polish Armed Forces}

On balance, the »Territorials« is a tactical formation whose members can be classified as special; their engagement and mode of behaviour jointly define the modern form of their service. The notion of »being brave« is augmented by »being socially responsible«. The modern warrior seems to be more about being talented and having a big heart than being strong. The Minister requires that the military service of today be multidisciplinary and multidimensional. So what about the main function of the up-to-date Polish Armed Forces? The times are changing and so are the requirements.

Both crisis management and military human resources are the guidelines for modern leadership and for many management sciences, and they are applied in research into the real functions of the Army and the expectations of the role that it is supposed to play today (Kaczmarczyk, 2018). The personality of the soldiers of this tactical formation consists of being on time, determined, positive, open, and empathetic, and understanding other people, especially seniors and the sick.

The activities of the Territorials shape the personality of Polish society. They teach it how to cope with crisis situations and how to be close to the Polish people and their problems, which makes them more suitable as citizens. They give guidance on how to help, how to be the »right« Polish. Apart from this, they set up role models for those young teenagers who do not know how to manage their futures and what career pathway to choose. The Army is the best way to test their psychological condition, their heart; the way to make out their sense of patriotism and readiness of being close to Polish citizens' needs, especially seniors. The realization of this may prove to be a starting point; an incentive to re-evaluate their attitudes and, consequently, become better, braver, more humane and emphatic people. Such qualities definitely contribute to the appreciation of the Polish soldiers' involvement in various cases of national expediency. The Polish Armed Forces owe this favourable social recognition to their displayed empathy. Regardless of their efforts and tiredness, soldiers are ready to meet challenges at any time. Polish society and the Polish Armed Forces teach each other how to look after the national goodness which is our country, Poland. Due to the fact that they attended infected Polish citizens, they truly set an example to follow. The programme (»Immune Spring«) is only one of a series implemented by the Polish Armed Forces. To sum up, the »Territorials « were and still are one of the irreplaceable forces, because of their suitable role in society. 
Figure 15:

Relationships

between

management

in the Polish

Armed Forces

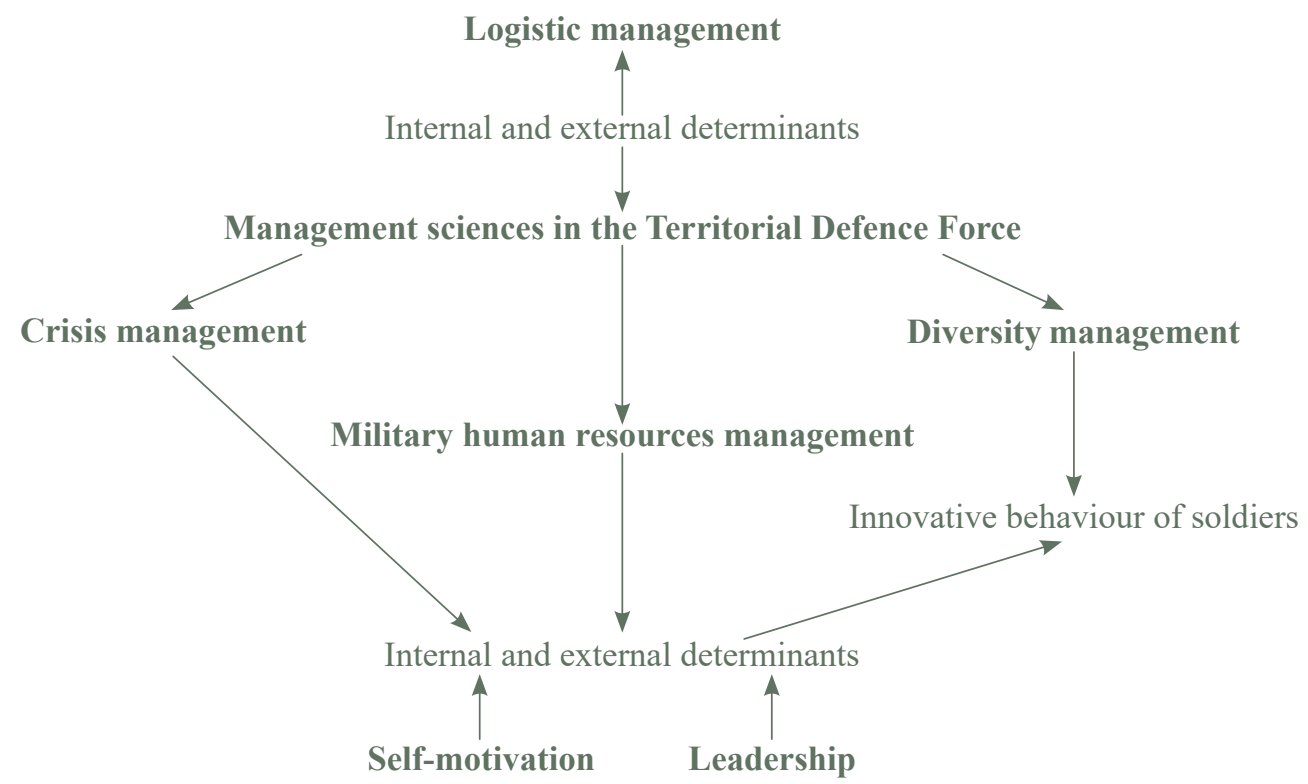

Logistic management

Internal and external determinants

The pandemic is the reason for the soldiers' attitude and innovative behaviour. From the scientific point of view, it is worthwhile to analyze them in order to match the internal and external factors which changed the medical situation and conditions (Franken, 2013). The internal factors are how soldiers should behave on their own, unaffected by the opinions of their colleagues in the Polish Armed Forces. External behaviour relates to real-life activities and the social side of personality: their cooperation and reliance on mutual trust, the role of luck and intuition in the operational and tactical teams of the Armed Forces. Internal and external engagement constitutes complementary evidence to the present research. The notion of an internal option refers to thinking about the way to be successful on the promotional ladder in the structures of the Polish Army, which motivates them to act and cope with all their operational and tactical tasks as a soldier (Zimbardo, Johnson, McCann, 2013). From the psychological point of view, motivation is the effect of biological, chemical and physiological reactions in the body or the brain, together with their emotional sides. Motivation also has another »face« - the reason for adjusting to the individual and collective pace of military service (Gasiul, 2021).

The roles demand both internal and external determinants. The pivotal external determinants are the world political situation and pharmaceutical companies' relations including many countries both on the European continent and beyond. The crucial internal determinants are the political situation of our country, internal military strategy, and military human resources. The conclusion is that, the external and internal elements determine the soldiers' behaviour and attitudes as an individual 
source of challenging and being active in social-military programmes, which also contributes to the protection of health and life.

Both soldiers and their leaders must cooperate in the especially difficult environment, because Polish society requires more than being brave and empathic. They may not forget about abiding by the restrictive, medical regime during their daily military service. Diversity in the Polish Armed Forces should be taken into account by leaders and each soldier. All soldiers are trained how to cope with medical situations. The soldiers problem-solving can be exemplary for those Polish people who do not know how to be close and supportive to a citizen, neighbour and how to be a good person in the modern world.

\begin{tabular}{|c|c|c|}
\hline The internal & Internal advantages & External advantages \\
\hline $\begin{array}{r}\text { and external } \\
\text { advantages } \\
\text { of diversity } \\
\text { management of } \\
\text { soldiers in the } \\
\text { Polish Armed } \\
\text { Forces }\end{array}$ & 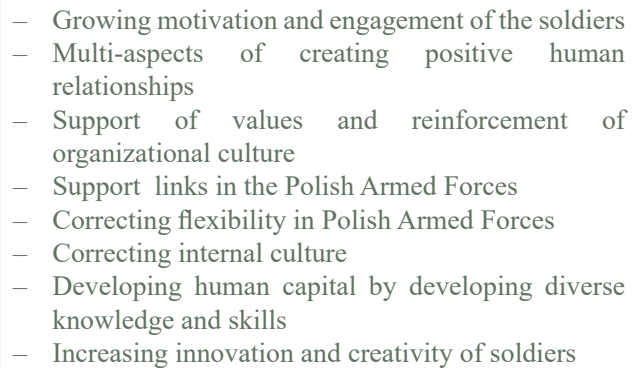 & $\begin{array}{l}\text { - Creating a positive reputation of the Polish Armed } \\
\text { Forces } \\
\text { - Growing flexibility in coping with the additional } \\
\text { challenges of the changing environment } \\
- \text { Changing the local work market for citizens } \\
- \text { Advantages of developing social responsibility of } \\
\text { the Army }\end{array}$ \\
\hline
\end{tabular}

Effective cooperation of the soldiers in the Polish Armed Forces requires both diversity (heterogeneity of knowledge which gives the opportunity to increase higher creativity and innovation) and similarity. The recruitment of candidates for soldiers to the team must be balanced heterogeneously and homogeneously for the soldiers to be an example to other soldiers and citizens. The necessity of developing skills and knowledge is a permanent feature and condition for changing all modern organizations, including the Polish Armed Forces.

To sum up, they promote how to be close to Polish citizens. The soldiers' motivation is the result of active and flexible military human management and leadership in the Polish Armed Forces. The logistic challenges of the Polish Armed Forces seem to be less important than human ones, because leaders have planned logistic reorganization and solutions before all military operations. 
Conclusion The Territorial soldiers implement the social, defence, psychosocial, and medical activities which have saved thousands and millions of Polish people - their lives and health.

Research conducted by the Military Office of Social Research shows that soldiers of the Territorial Military Service join the Territorial Defence Forces for patriotic reasons and a desire for personal development, both mentally and in knowledge and skills. They evaluate the programme and the course of the basic training positively, because it gives a good preparation for the service. The vast majority of TMS soldiers declare their willingness to stay in the army for a longer period, and half would like to become professional soldiers.

The soldiers of the operational troops believe that the actions of the TDF should primarily concern emergency and crisis situations, support the civilian population, and defend the nearby territory. Half of them assess the TDF positively in various respects, such as the concept of their function, training, or communication with other types of Polish Armed Forces.

The social research presented in the article shows that Polish citizens expected the actions of the Territorial Defence Forces in the context of combating the effects of modern natural and other disasters, which became real during the Covid-19 pandemic. Research also shows that the acceptance of the creation of the Territorial Defence Forces does not always go hand in hand with the willingness to enter such service personally. However, a positive attitude towards this type of armed forces, especially among the younger generations of Poles, seems to be important.

This article does not include all knowledge of the Territorial Defence Forces, but it can be a reason to have discussion about their roles, structures, and payment system, including the motivation system. To sum up, the authors recommend that social perception should be researched and analyzed.

1. Franken, R. E., 2013. Psychologia motywacji, Gdańskie Wydawnictwo Psychologiczne, Gdańsk.

2. Gasiul, H., 2012. Psychologia osobowości. Nurty, teorie, koncepcje, Difin, Warszawa.

3. Gasiorek, K., Marek, A., 2020. Działania Wojsk Obrony Terytorialnej podczas pandemii COVID-19 jako przykład wojskowego wsparcia władz cywilnych $i$ społeczeństwa, Wiedza Obronna, Vol. 272, No. 3.

4. Hac, P., 2020. Współdziałanie wybranych podmiotów bezpieczeństwa wewnętrznego w Polsce w warunkach epidemii COVID-19 - znaczenie oraz wyzwania, Wiedza Obronna, Vol. 272 No. 3 .

5. Horyń, W., 2019. Wojska Obrony terytorialnej w czasie niemilitarnych zdarzeń nadzwyczajnych, Bellona, Warszawa.

6. Jakubczak, R., Marczak, J., 1998. Obrona Terytorialna Polski na progu XXI wieku, Bellona, Warszawa. 
7. Jeruszka, U., Wolan-Nowakowska, M., 2020. Zarządzanie różnorodnością w organizacji. Aspekty psychopedagogiczne, Difin, Warszawa.

8. Kaczmarczyk, B., 2018. Selected problems of education for safety in the changing environment of threats, "Zeszyty Naukowe PWSZ im. Wielona w Legnicy«, nr 26 (1).

9. Kośmider, T., Gąsiorek, K., 2017. Powszechna Obrona Terytorialna odstawa bezpieczeństwa narodowego Rzeczypospolitej Polskiej, [w] Wojska Obrony Terytorialnej $w$ Polsce i na świecie $w$ drugiej dekadzie XXI wieku. Bezpieczeństwo. Teoria i Praktyka nr 3 (XXVIII), Oficyna Wydawnicza AFM.

10. Kukuła, A., 2020. Działania Wojsk Obrony Terytorialnej w obliczu zagrożenia, jakim jest SARS-COV-2, Zeszyty Naukowe Państwowej Wyższej Szkoły Zawodowej im. Witelona w Legnicy, $n r 36$ (3).

11. Wziątek-Staśko, A., 2012. Diversity management. Narzędzie skutecznego motywowania pracowników, Difin, Warszawa.

12. Zimbardo, P. G, Johnson, R. L., McCann, V., 2013. Psychologia. Kluczowe koncepcje. Motywacja i uczenie się, Wydawnictwo Naukowe PWN, Warszawa.

13. Zimbardo, P. G, Johnson, R. L., McCann, V., 2013. Psychologia. Kluczowe koncepcje. Psychologia osobowości, Wydawnictwo Naukowe PWN, Warszawa.

\section{Reports}

1. Predel, G., Iwanek, M., Ocena wybranych aspektów stużby wojskowej w WOT (TSW) I NSR oraz ćwiczén żotnierzy rezerwy, Wojskowe Biuro Badań Społecznych/Wojskowe Centrum Edukacji Obywatelskiej, Warszawa, luty 2019.

2. Iwanek, M., Kiciński, Ł., Stużba w Wojskach Obrony Terytorialnej w opinii żotnierzy zawodowych, Wojskowe Biuro Badań Społecznych/Wojskowe Centrum Edukacji Obywatelskiej, Warszawa, styczeń 2021.

3. Wizerunek Wojska Polskiego, raport z badania dla Wojskowego Centrum Edukacji Obywatelskiej, ARC Rynek i Opinia, październik 2019, Warszawa.

4. Wojska Obrony Terytorialnej Wyniki badania sondażowego, raport z badania dla Wojskowego Centrum Edukacji Obywatelskiej, CBOS, styczeń 2017, Warszawa. 


\section{NASILNA DEJANJA NAD ZDRAVSTVENIMI USTANOVAMI IN NJIHOVIMI ZAPOSLENIMI NA MADŽARSKEM}

Povzetek Namen te presečne kvantitativne raziskave je ugotoviti, katera oblika nasilja je $\mathrm{v}$ madžarskih zdravstvenih ustanovah najpogostejša. Z njo želimo oceniti, ali se v teh ustanovah izvaja usposabljanje za komunikacijo, simulacijo in samoobrambo. Cilj je ugotoviti, ali bi se zaposleni udeležili takega usposabljanja, in oceniti povezanost med usposobljenostjo (komunikacija, simulacija, samoobramba) ter stopnjo samozavesti. Žrtve večine nasilnih dejanj pacientov so zdravstveni delavci. Najpogostejša oblika agresije pacientov in njihovih svojcev je verbalna agresija, vključno z zbadanjem, verbalno zlorabo in grožnjami z zlorabo. Podatki kažejo, da le usposabljanje v komunikaciji ni dovolj za dvig samozavesti pri zdravstvenih delavcih. Treba jim je zagotoviti orodje, kot so na primer praktične vaje po usposabljanju iz samoobrambe.

Ključne besede

Abstract

The present cross-sectional quantitative research aims to gain a sense of which form of violence is the most common in Hungarian healthcare institutions. It aims to assess whether communication, simulation, and self-defence training is provided in institutions, to find out whether workers would participate in such training, and to assess the relationship between training (communication, simulation, self-defence) and confidence. Healthcare workers are affected by most acts of violence coming from patients. The most common type of aggression on the part of patients and relatives is verbal aggression, including teasing, verbal abuse, and threats of abuse. The data show that communication training alone is not enough to make health workers confident. They should have a tool in their hands, e.g., practice after selfdefence education, simulation practice, as this makes it easier for the employee to communicate.

Aggression, healthcare, prevention, training, self-defence, confidence. 
Introduction Today, when the topic of healthcare comes up, it is almost all about the Covid-19 pandemic and the heroic struggle of the health workers who are fighting against it. One can read mainly about the situation in Europe and the United States, but there is also more and more alarming information about the African continent (Besenyö, Kármán, 2020, p 633). However, there are other very important issues in this topic, for example, violence in the health sector. This is widespread in all countries and affects all professions in the health sector. One of the most shocking forms is terrorist attacks on healthcare facilities. Boaz Ganor and Miri Halperin Wernli, two Israeli scholars, issued a working paper in 2013 that covered more than 100 terror events against hospitals in the period 1981-2013 in 43 countries (Boaz, Miri, 2013, p 4). The authors found that 775 people had lost their lives and another 1,217 were injured in the attacks. From 1 January, 1970, to 31 December, 2020, there were 961 attacks in 76 countries against healthcare facilities and healthcare workers at these institutions. In total, 3,006 people died and 4,673 were injured (Besenyő, Márton, Shaffer, 2021, $\mathrm{p} 7$ ). The highest risk to healthcare facilities is bombing or an explosive attack, but armed attacks pose another significant threat to hospitals (Ibid, p 9). Every hospital must be prepared for these attacks with well-developed prevention plans, in which the preparation and education of the employees are not insignificant (RáczkevyDeák, 2020, p 98; Deák, 2011, p 130). However, due to reasons of length and the research complexity of this area, I do not intend to cover this topic extensively.

Comparative research demonstrates that violence against staff in hospitals and healthcare institutions affects both industrialized and developing countries, and that verbal violence is as present as physical violence. Violence against medical personnel damages not only the health and dignity of employees, but also the productivity of organizations. Violence in healthcare also poses a threat to patient safety and the quality of patient care. Online sites such as Google Scholar, Scopus, PubMed and so on also testify that thousands of studies have been written in recent years on this topic. We can see that studies by professionals and organizations show no reduction in the number of atrocities or verbal and physical violence: in Sweden (Arnetz, Petterson 1996, p 119), 29\% of health workers have experienced violence at some point; the proportion is $25 \%$ in the US (ANA) and $44.7 \%$ in Turkey (Pinar, Acikel, Karabulut et al. 2017, pp 23-45). According to the World Health Organization (WHO), 8-38\% of health workers experience some form of physical violence during their careers (WHO, 2008). In a 2019 survey of more than 5,000 nurses by the American Nurses Association (ANA), 59\% said they had been verbally abused and one in four had been physically abused by a patient (ANA).

According to the Criminal Statistics System of the Hungarian Police (ENYÜBS), between 2017 and 2018 there were 18 cases of nurses with higher qualifications, 55 cases of nurses, 33 cases of doctors, and 9 cases of general health assistants in connection with bodily harm, harassment, and violence against a person performing public duties (BM document ENYÜBSZ, 2018). These are only cases according to the number of reported and known perpetrators; many more occur in Hungarian hospitals, but as there is no reporting obligation, a large number of atrocities remain 
hidden. Evidently, despite the high exposure to violence in the health sector, the number is very much underestimated (ANA, Henson, 2008, p 574; Sharipova, Borg 2008, pp 574-581).

There is still very little research in Hungary dealing with this problem, although the number of these actions has not decreased. ${ }^{1}$ Every day we see in the news nurses and doctors who have suffered minor or more serious bodily injuries. We have very little data on verbal violence, as it often remains hidden from management and the media. Hidden victims continue to work with various symptoms (such as post-traumatic stress disorder (PTSD)) after the forms of violence they have suffered, thereby endangering patient safety (Besenyő, Deák, 2011, p 22).

In Hungary, one of the first studies to assess and study how to prevent or reduce atrocities was conducted in 2010. This quantitative and qualitative research was carried out in a hospital in the capital, Budapest, and confirmed that aggressive acts are becoming more frequent in hospitals (number of respondents 85, interview subjects 50). As many as $70 \%$ of respondents had experienced verbal violence and $20 \%$ physical violence, and only $10 \%$ said they had not been affected by any form of violence. There was no reporting obligation, and very often they did not even know who to turn to after verbal or physical violence (Deák, 2012, pp 180-189). Many accepted the harm they suffered as part of their health work. This may have contributed to the large number of burnt-out (Irinyi, 2018), indifferent workers in Hungarian healthcare. A total of $95 \%$ of the respondents were not aware of or had not heard about aggression prevention training. A small number of articles providing useful data have been published since 2010, but no comprehensive research has been conducted on violence prevention training. ${ }^{2}$

In this article, I present some of my latest questionnaire research. The questions asked mostly concern the number and type of atrocities and their impact on the confidence of healthcare workers. In addition, the questionnaire pays great attention to violence prevention training, as only a worker who is properly trained in violence can communicate both assertively and empathetically and intervene effectively if the behaviour of a patient or relative is inappropriate.

The principle of zero tolerance and the punishment of violence against a person performing a public task is not enough to prevent it. ${ }^{3}$ Only a combination of training in violent patient recognition and de-escalation methods and non-violent communication, assertive communication training, and their practice in simulation

\footnotetext{
Articles and studies have been written on such topics, among others: Besenyö, J., Deák, G., Irinyi., T, Ivánka T., Németh A. Rudisch T. et al. (see bibliography).

2 For communication training pre and post data see more details: Ivánka, T., Irinyi, T., Rudisch, T., et al. 2014, 27(4), pp 11-17.

3 Violence against an official: Section 310 of the Criminal Code (1) Whoever obstructs an official or a foreign official in his or her lawful proceedings by force or threat, b) forces him or her to take action in his or her lawful proceedings, or shall be punishable by one to five years'imprisonment.
} 
exercises can lead to success. Last but not least, self-defence education can also be very helpful if security staff are not able to intervene promptly; this type of education already exists in healthcare facilities in several countries (Bugala, Reguli, 2016; Lamont, Brunero, 2012, p 313; Dickens, Rogers, 2009, p 777). The professional chambers in Hungary (Hungarian Medical Chamber (MOK), Hungarian Chamber of Healthcare Workers (MESZK)) have never held self-defence training, and many even rigidly reject it from the management, arguing that it is not the job of healthcare workers to deal with life-threatening situations. Security personnel are trained for this. However, if we look at the news, not long ago (March 20, 2021) there was an attack with very serious consequences in a hospital in the capital. ${ }^{4}$ Although several nurses worked in the intensive care unit at the time, they were unable to protect themselves or their patients from a mentally disturbed patient who was threatening and injuring people with a cutting tool. Physical violence is also common in psychiatric wards. ${ }^{5}$ After good quality and long-lasting self-defence education, a worker becomes more confident and experienced, and may be able to protect themselves and their patients. Forms of violence involving death and injury have also occurred in neighbouring countries. In 2019 there was serious physical violence in a Romanian psychiatry ward; four patients died and many were injured, and only the police were able to restrain the disturbed patient. ${ }^{6}$ In the Czech Republic, there was a shooting at an outpatient clinic at the University Hospital in Ostrava, killing six people and injuring three in a traumatology department attack. ${ }^{7}$

\section{METHODS}

The research objectives were to discover which form of violence is most common in Hungarian healthcare institutions; whether physical violence is more common during outpatient or inpatient care; whether communication, simulation, and self-defence training is held in institutes and if so, in what form, and whether healthcare workers would participate in such training; and to assess the relationship of certain violence

\footnotetext{
4 The incident took place in the Covid ward of the Military Hospital Budapest. Arriving at the ward following the screams of one of the female patients, a nurse saw a man clutching the woman's neck with one hand and hitting her chest with the other. The disturbed patient, seeing the nurse, grabbed a pair of scissors and headed for the nurse, who backed down the hall. Meanwhile, another nurse had already arrived, so two had now tried to curb the attacker. They reached another ward while retreating. The man went in here, ripped the tubes out of the mouth of a patient under anesthesia and being ventilated, then hit the head of the patient lying there with scissors nearly 30 times. The woman did not survive her injuries. See more: https://ripost.hu/politik/insider/ korhazi-keseles-kegyetlen-reszletek-honvedkorhaz-2804572/ (in Hungarian, 2021.04.06.)

5 According to Hungarian 2017 research $(N=1201)$, in the psychiatric ward 49,4\% of the respondents had suffered a mild injury fewer than 10 times. In addition to this class, the SBO (Department of Emergency Care) also had a high rate of physical violence (Irinyi T., Németh A.., Lampek K.,2017, pp 229-237)

${ }_{6}$ Five fell victim to a bloodbath in Romania organized by a patient at a neuropsychiatric hospital in Sapoca. The confused patient wounded four patients and injured nine more with an infusion stand. The incident was preceded by a series of human omissions. For example, nurses' job descriptions stated that they should not leave objects in the hands of patients that could injure them, so the infusion stand should not have been left in the ward. http://medicalonline.hu/kitekinto/cikk/verfurdo_egy_romaniai_pszichiatrian (in Hungarian, 2021.06.06)

7 See more:https://www.origo.hu/nagyvilag/20191210-lovoldozes-egy-ostravai-korhazban-tobben-meghaltak.html (in Hungarian, 2021.06.06.)
} 
prevention and treatment training (communication, simulation, self-defence) with confidence.

In the study, the form of the aggressive actions, the correlation of training with selfconfidence, and the number of atrocities suffered were examined empirically using a quantitative tool. Before the research, the literature was analyzed and an inductive research strategy was used.

The survey was conducted between 3 October 2020 and 10 January 2021. The questionnaire was prepared with the help of the online questionnaire website, and was made available online on the community page of the Hungarian Chamber of Healthcare Professionals (MESZK) and on the community pages of groups of health workers, while the National Ambulance Service (OMSZ) sent it to its members by email. Sampling was carried out by a non-random sampling procedure, including convenience sampling. The advantage of this sampling method is that many subjects can be reached in a short time. The disadvantage, however, is that it is not representative, and only health professionals who have an email address or members of the Hungarian Chamber of Healthcare Professionals and the social workers' groups could be included in the sample.

In the description at the beginning of the questionnaire, the participants were informed of the purpose of the research, the completion of the questionnaire, anonymity, and volunteering. By completing the questionnaire, the participants consented to the use of their responses. The selection criterion was at least one year's employment in healthcare, working in Hungary. A total of 740 submissions were received. Of these, those who had not worked in healthcare for at least a year or who answered only a few questions were excluded. There were 720 completed questionnaires remaining, which were later analyzed. However, not all of these 720 individuals answered all the questions either, so I will address some of the questions to the respondents.

The first part of the self-edited questionnaire included self-prepared questions on socio-demographic information and working conditions. In the second part of the questionnaire, I was curious about each form of violence as well as the number of incidents. I created my own questions, using the questions of the Overt aggression questionnaire as a sample (Yudofsky. S.C. Silver, J.M Jackson, W. Endicott,J. Williams 1986, pp 35-39). In the questionnaire, verbal and physical violence were separated, and the respondents were asked about the forms of aggression that they had experienced in healthcare and in the last 12 months of their work. The degree of coping with patients' aggression was measured using the Confidence Scale (How confident do you feel in the presence of an aggressive patient?) developed by Thackrey (1986, pp 57-60). The series of questions consisted of 10 items, which were evaluated on an 11-point scale. The ranges varied depending on the question: »Very disturbing« or »Not disturbing at all«, »Not helpful at all« or »Very helpful«, $» \mathrm{I}$ am not able to do it $\ll$ or $» \mathrm{I}$ am able to do it «, »I am not really confident $«$ or $» \mathrm{I}$ am 
confident «. This measurement instrument is most commonly used to measure the effectiveness of training in violence prevention.

Data processing and data analysis was performed with the IBM SPSS 23.0 for Windows statistical program. Of the descriptive statistical methods, the mean, standard deviation (SD), median, minimum and maximum, and absolute and relative frequencies were calculated. Of the mathematical-statistical methods, the following tests were used: the Wilcoxon test to compare the means of non-normally distributed variables; the Spearman rank correlation to examine the correlation of non-normally distributed continuous variables; the Kruskal-Wallis test; the Mann-Whitney test; the Chi-square test; Anova; Levene; the independent pattern T-test; and Pearson's linear correlation coefficient. The results were considered significant at $\mathrm{p}<0.05$.

\section{RESULTS}

Socio-demographic data: Of the 720 respondents, 700 answered the gender ratio question, which showed that $88 \%$ (616) were women and $12 \%(84)$ were men. Their mean age was 45.5 years $($ median $=46$ years; $\mathrm{SD}($ standard deviation $)=9.89$; Min $=$ 20 ; Max $=76$ ). Concerning education, $56 \%$ of the sample had a high school diploma plus training from the National Training List (OKJ) (403); while graduates made up $35.84 \%$ of the sample (257). The largest number (24\%) were from Budapest, and $13.6 \%$ were from Pest County, with significantly fewer responses from other counties. In terms of workplace characteristics, the survey participants had worked in healthcare for an average of 22.85 years (median $=24$ years; $\mathrm{SD}=11.47$; $\operatorname{Min}=0.5$; Max: =52). Examining the level of healthcare, of 716 respondents $10 \%(70)$ worked in primary care; $20 \%$ (144) in outpatient care; $62 \%$ (441) in inpatient care; and 8\% (61 people) in ambulance services. The largest proportions of the respondents worked in internal medicine, psychiatry, basic care, intensive care, surgery, emergency care, and ambulance services. However, they worked in almost every field of healthcare, so there was also an »other « category (without claiming completeness: rheumatology, pulmonary medicine, urology, administration, diagnostics, gynaecology, etc.).

Questions about aggressive incidents: In the research, I wondered who the respondents received help from during the aggressive incidents they had experienced. For this question, the responses of 638 respondents were taken into account, as a great many gave ambiguous answers or were not affected by aggressive action. Most received help from their immediate colleagues: other nurses $(59 \%)$, followed by doctors $(26 \%)$ and the security service $(22 \%)$, and $12 \%$ of respondents did not receive any help (Figure 1). 


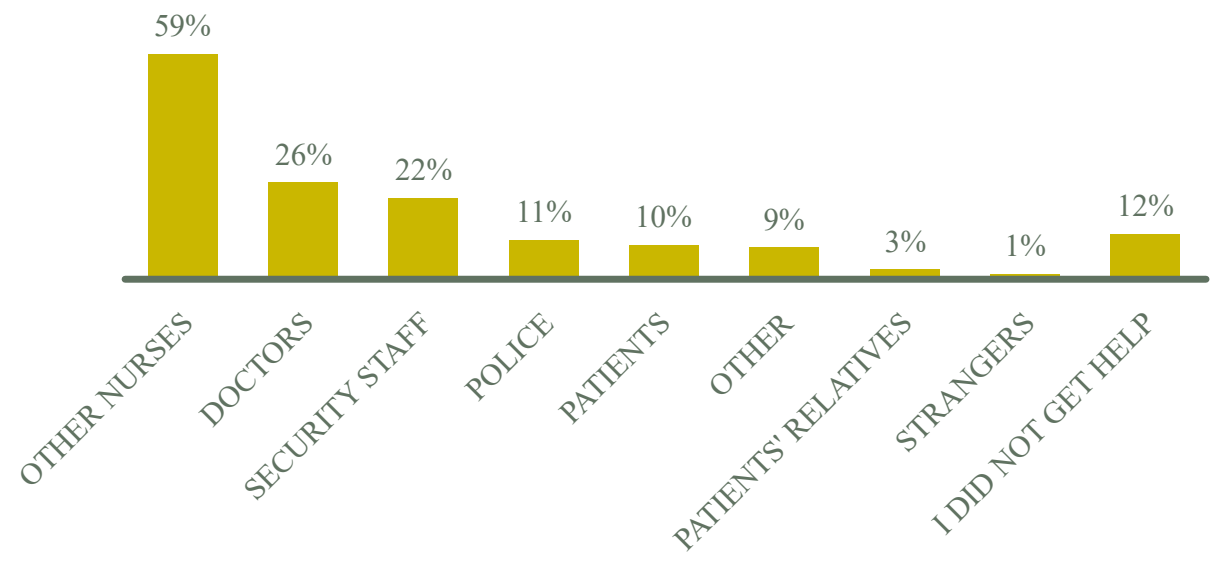

After the aggressive incident, most respondents turned to a head nurse $(21 \%)$ or a psychologist (19\%). Even the chief physician of the department (12\%) was indicated.

More acts of violence occur during the day, which includes both morning and afternoon shifts, so $2 / 3$ of each 24 hours is regarded as day, and $1 / 3$ as night. However, while there is less patient traffic at night, as patients are sleeping, there is still a great deal of violence. There needs to be further analysis of what triggers these aggressive incidents.

The place of aggression is usually the ward or unit and the corridors of the institution. Under other categories, the patient's home and inside the ambulance appeared several times, as ambulance staff are most affected by acts of violence in these places.

Questions modelled on the Overt Aggression Scale (Yudofsky. S.C., Silver, J.M., Jackson, W., Endicott, J., Williams, D., 1986) asked which forms of violence dominated among the respondents and how many times they had been affected by them. Specifically, the respondents were asked how many times these forms of violence came from a patient, a relative, or a colleague. Several questions asked how many times the respondents had experienced that particular aggressive manifestation from a patient, relative, or colleague since they had worked in healthcare. The most common type of aggression on the part of patients was verbal aggression, including teasing, verbal insults, and threats of abuse. Among the incidence of physical aggression, physical threat (non-verbal, e.g. threatening physical movements) and abuse causing minor injury predominate, while abuse causing more severe injury is significantly less (See Table 1). Verbal aggression is most prevalent on the part of relatives. 


\begin{tabular}{|c|c|c|c|c|c|c|}
\hline \multirow{16}{*}{$\begin{array}{r}\text { Table 1: } \\
\text { Frequency (\%) } \\
\text { of experiencing } \\
\text { aggression } \\
\text { from patients/ } \\
\text { relatives/ } \\
\text { colleagues }\end{array}$} & & Never & $\begin{array}{c}\text { Less than } 5 \\
\text { times }\end{array}$ & 5-10 times & $11-20$ times & $\begin{array}{l}\text { More than } 21 \\
\text { times }\end{array}$ \\
\hline & & $\mathrm{P} / \mathrm{R} / \mathrm{C}$ & $\mathrm{P} / \mathrm{R} / \mathrm{C}$ & $\mathrm{P} / \mathrm{R} / \mathrm{C}$ & $\mathrm{P} / \mathrm{R} / \mathrm{C}$ & $\mathrm{P} / \mathrm{R} / \mathrm{C}$ \\
\hline & Verbal aggression & & & & & \\
\hline & $\begin{array}{c}\text { Verbal threat of } \\
\text { abuse }\end{array}$ & $16.2 / 35.4 / 76.3$ & 25.9/33/17.2 & $19.9 / 13.2 / 2.4$ & $9.5 / 5.9 / 1.7$ & $28.6 / 12.5 / 2.3$ \\
\hline & $\begin{array}{c}\text { Sexual } \\
\text { harassment }\end{array}$ & $59.7 / 85.7 / 73.7$ & $28.2 / 11.4 / 17.9$ & $6.9 / 1.5 / 4.8$ & $3.1 / 1.2 / 1.9$ & $2.1 / 0.3 / 1.7$ \\
\hline & Verbal abuse & $5.9 / 18.2 / 35.3$ & $16.9 / 30.9 / 33.4$ & $15.3 / 15.2 / 11.8$ & $11.9 / 10.9 / 7.6$ & $50.6 / 24.7 / 11.9$ \\
\hline & Scoffing/teasing & $5.5 / 19.4 / 27.3$ & $14.2 / 28.7 / 29.6$ & $14.3 / 15.9 / 14.9$ & $14.9 / 11 / 8.8$ & $51.1 / 25 / 19.4$ \\
\hline & $\begin{array}{l}\text { Threatening } \\
\text { letters, telephone } \\
\text { harassment }\end{array}$ & $80.1 / 82.7 / 89$ & $14.1 / 11.2 / 8.4$ & $3.2 / 2.9 / 0.9$ & $1.2 / 0.9 / 0.6$ & $1.5 / 2.3 / 1.2$ \\
\hline & Humiliation & $25.1 / 43.5 / 31.4$ & $34.1 / 28.2 / 28.4$ & $12.3 / 10.9 / 14.5$ & 7.5/6.1/9.3 & 20.9/11.3/19.6 \\
\hline & $\begin{array}{l}\text { Intimidation - } \\
\text { elevated tone, } \\
\text { shouting }\end{array}$ & $32.6 / 52.4 / 45.8$ & $36 / 26.7 / 28.9$ & $12.3 / 7.4 / 7.8$ & $6.8 / 3.6 / 4.4$ & 12.3/9.9/13.1 \\
\hline & Harassment & $61.9 / 78 / 78$ & 27/14.2/11.9 & $4 / 2.9 / 3.6$ & $3 / 1.8 / 2.4$ & 4.1/3.1/4.1 \\
\hline & $\begin{array}{l}\text { Physical } \\
\text { aggression }\end{array}$ & & & & & \\
\hline & $\begin{array}{l}\text { Physical threat } \\
\text { (non-verbal, } \\
\text { eg. threatening } \\
\text { movements) }\end{array}$ & $20.9 / 47.4 / 84.2$ & $31.5 / 30.3 / 11.9$ & $19.6 / 9.7 / 2.1$ & $9.7 / 4.9 / 0.4$ & 18.2/7.7/1.3 \\
\hline & $\begin{array}{l}\text { Mild injury (e.g. } \\
\text { beating) that } \\
\text { did not require } \\
\text { medical treatment }\end{array}$ & $53.6 / 90.2 / 97.2$ & $30.1 / 8.1 / 2.5$ & 7.1/0.7/0.1 & $4.2 / 0.3 / 0.1$ & $4.9 / 0.6 / 0$ \\
\hline & $\begin{array}{l}\text { More severe } \\
\text { injuries that } \\
\text { required medical } \\
\text { treatment }\end{array}$ & $90.5 / 97.9 / 99$ & 8.2/1.3/0.9 & $1.2 / 0.4 / 0$ & $0.1 / 0.1 / 0.1$ & $0 / 0.1 / 0$ \\
\hline & $\begin{array}{l}\mathrm{P}=\text { Patients; } \\
\mathrm{R}=\text { Relatives; } \\
\mathrm{C}=\text { Colleagues }\end{array}$ & & & & & \\
\hline
\end{tabular}

I was also curious about what had happened in the 12 months before completing the questionnaire. A similar trend as in the previous question can be observed in the experience of each aggressive act for each type of violence. With regard to verbal aggression, the most frequently mentioned was the threat of scoffing/teasing, verbal abuse, and general abuse (Table 2). 


\begin{tabular}{|c|c|c|c|c|c|c|}
\hline \multirow{16}{*}{$\begin{array}{r}\text { Table 2: } \\
\text { Frequency of } \\
\text { experiencing } \\
\text { aggression (\%) } \\
\text { from patients/ } \\
\text { relatives/ } \\
\text { colleagues in the } \\
\text { last } 12 \text { months } \\
(2020)\end{array}$} & & Never & $\begin{array}{c}\text { Less than } 5 \\
\text { times }\end{array}$ & 5-10 times & $11-20$ times & $\begin{array}{c}\text { More than } 21 \\
\text { times }\end{array}$ \\
\hline & & $\mathrm{P} / \mathrm{R} / \mathrm{C}$ & $\mathrm{P} / \mathrm{R} / \mathrm{C}$ & $\mathrm{P} / \mathrm{R} / \mathrm{C}$ & $\mathrm{P} / \mathrm{R} / \mathrm{C}$ & $P / R / C$ \\
\hline & Verbal aggression & & & & & \\
\hline & $\begin{array}{c}\text { Verbal threat of } \\
\text { abuse }\end{array}$ & $42.9 / 60.5 / 88.6$ & $36.5 / 27.4 / 7.2$ & $10.5 / 6.9 / 0.9$ & $3.8 / 1.7 / 1.2$ & $6.3 / 3.5 / 2.1$ \\
\hline & $\begin{array}{c}\text { Sexual } \\
\text { harassment }\end{array}$ & $85 / 94.9 / 91.8$ & $11.4 / 4.3 / 5.6$ & $2.8 / 0.5 / 1.2$ & $0.3 / 0.3 / 0.3$ & $0.4 / 0 / 1.1 / 5.5$ \\
\hline & Verbal abuse & $21.6 / 38.5 / 55.9$ & $34.2 / 34 / 28.6$ & 18.6/12.8/7.0 & 9.5/6.8/2.9 & $16.1 / 8 / 5.5$ \\
\hline & Scoffing/teasing & $21.5 / 37.4 / 45.4$ & $32 / 34.6 / 30.5$ & $18.7 / 11.4 / 9.5$ & $9.6 / 7.8 / 5.2$ & $18.1 / 8.8 / 9.5$ \\
\hline & $\begin{array}{c}\text { Threatening } \\
\text { letters, telephone } \\
\text { harassment }\end{array}$ & $89.1 / 89.1 / 95.9$ & $8 / 8.1 / 1.7$ & $1.4 / 1.4 / 0.9$ & $1.1 / 0.8 / 0.6$ & $0.5 / 0.6 / 0.9$ \\
\hline & Humiliation & $50.4 / 61 / 54.5$ & $28 / 23.8 / 30$ & $10.1 / 7.5 / 8$ & $5.7 / 3.8 / 4.9$ & $5.8 / 3.9 / 8.9$ \\
\hline & $\begin{array}{l}\text { Intimidation - } \\
\text { elevated tone, } \\
\text { shouting }\end{array}$ & $62.9 / 70.4 / 66$ & 24/19/20.4 & $5.6 / 5.3 / 4.4$ & $3.9 / 1.6 / 2.7$ & $3.7 / 3.7 / 6.5$ \\
\hline & Harassment & $80.9 / 87.4 / 88.7$ & 13.9/8.6/6.1 & 2.3/1.9/1.9 & $1.4 / 0.6 / 0.9$ & $1.5 / 1.4 / 2.4$ \\
\hline & $\begin{array}{l}\text { Physical } \\
\text { aggression }\end{array}$ & & & & & \\
\hline & $\begin{array}{l}\text { Physical threat } \\
\text { (non-verbal, } \\
\text { eg. threatening } \\
\text { movements) }\end{array}$ & $47.8 / 71.3 / 93.9$ & $34.5 / 21.7 / 3.8$ & $8.3 / 4.4 / 0.6$ & $4.2 / 0.8 / 0.6$ & $5.1 / 1.8 / 1.4$ \\
\hline & $\begin{array}{l}\text { Mild injury (e.g. } \\
\text { beating) that } \\
\text { did not require } \\
\text { medical treatment }\end{array}$ & 75.7/96.1/98.3 & 18.4/3.3/1.1 & $2.6 / 0.2 / 0.3$ & $2 / 0.3 / 0.2$ & $1.4 / 0.2 / 0.2$ \\
\hline & $\begin{array}{l}\text { More severe } \\
\text { injuries that } \\
\text { required medical } \\
\text { treatment }\end{array}$ & $96.5 / 99.4 / 99.7$ & $3.2 / 0.5 / 0.2$ & $0.3 / 0.2 / 0.2$ & $0 / 0 / 0$ & $0 / 0 / 0$ \\
\hline & $\begin{array}{l}\mathrm{P}=\text { Patients; } \\
\mathrm{R}=\text { Relatives; } \\
\mathrm{C}=\text { Colleagues }\end{array}$ & & & & & \\
\hline
\end{tabular}

Aggression means show a significant difference between patients. I examined them as types of aggression by repeated-measures analysis of variance. Various tests (Pillai's Trace, Wilks' Lambda, Hotelling's Trace, Roy's Largest Root) lead to the conclusion that there is a significant difference in verbal acts of violence (Wilks' $\lambda=$ $0.244 ; \mathrm{F}(11 ; 412)=116.149 ; \mathrm{p}<0.001 ; \eta 2=0.756)$. Each type of aggression appears with a different frequency, the most common being scoffing/teasing, verbal abuse, and verbal threats of abuse from patients, relatives, and colleagues (Figure 2). 
Figure 2:

The average

incidence of

aggression types

from patients in

total

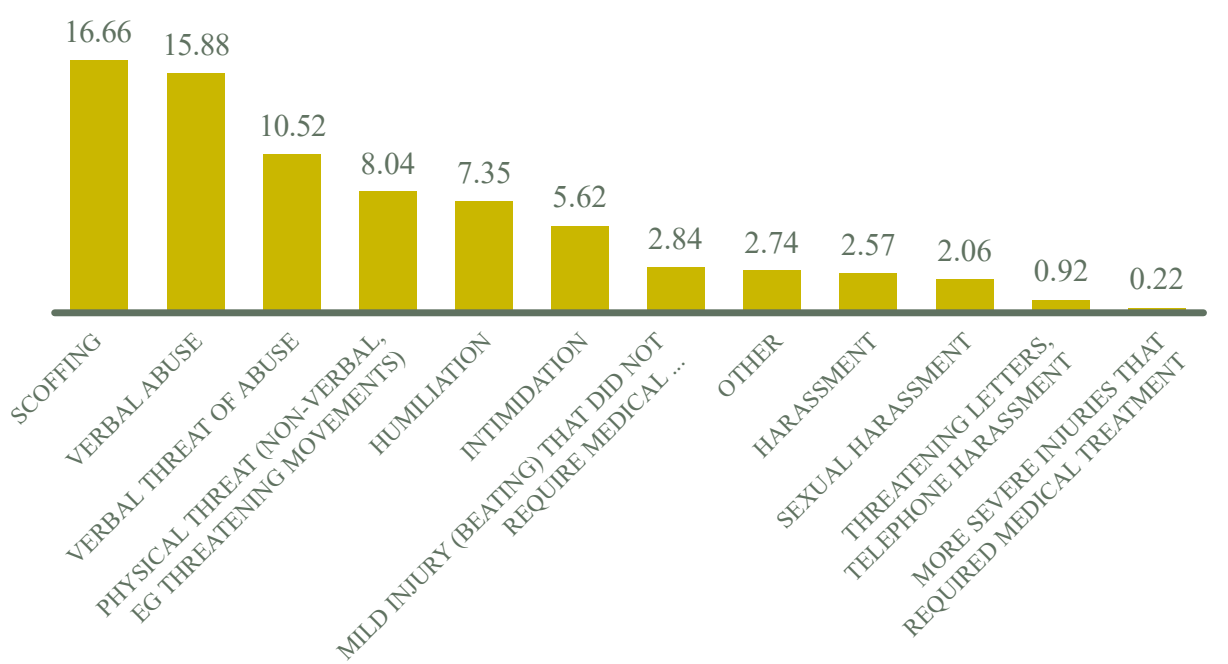

I replaced the Likert scale (5-point) values with the middle of the given interval: 0-5 to $3,6-10$ to 8 , and so on. Projecting the number of violent acts committed by patients on an annual basis based on the length of service, it can be seen that the difference in verbal violence is significant (Wilks' $\lambda=0.64 ; \mathrm{F}(11 ; 704)=35.980 ; \mathrm{p}$ $<0.001 ; \eta 2=0.36$ ) (Figure 3).

Figure 3:

The average

incidence

of types of

aggression per year committed

by patients

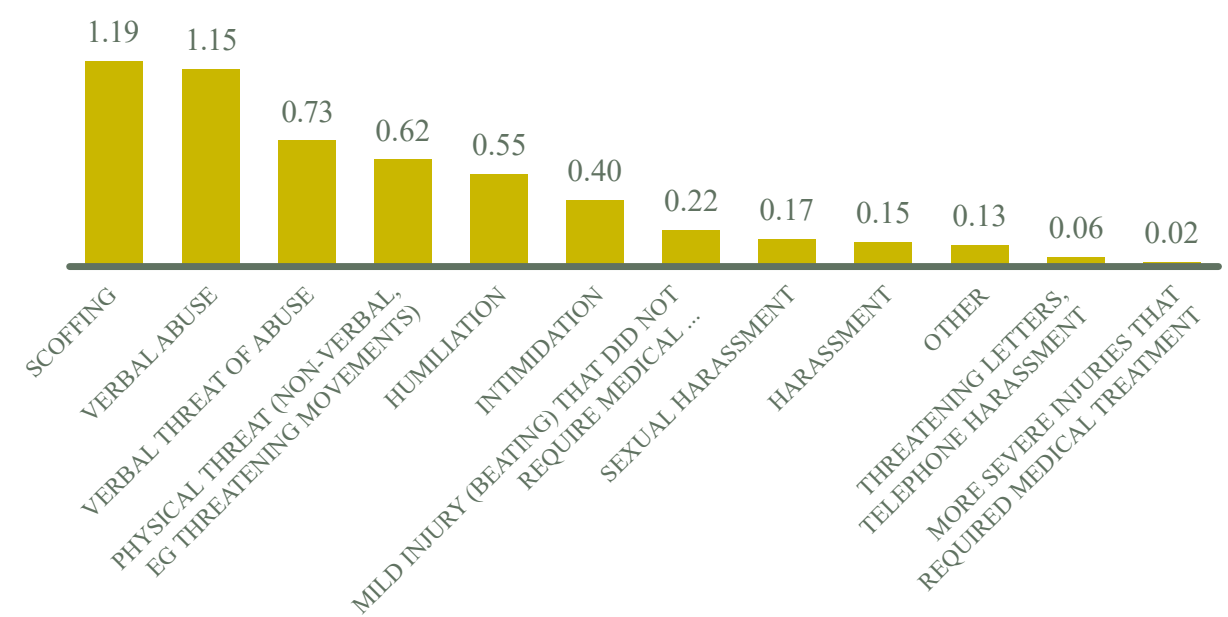

The question of the forms of violence suffered by patients also shows that the difference in verbal acts of violence is also significant among the average aggressive acts of patients in the past 12 months (Wilks' Lambda test) (Wilks' $\lambda=0.553$; F (11; $433)=31.783 ; \mathrm{p}<0.001 ; \eta 2=0.447)($ Figure 4$)$. 
Figure 4:

The average

incidence

of types of

aggression

committed by

patients in the

past year (2020)

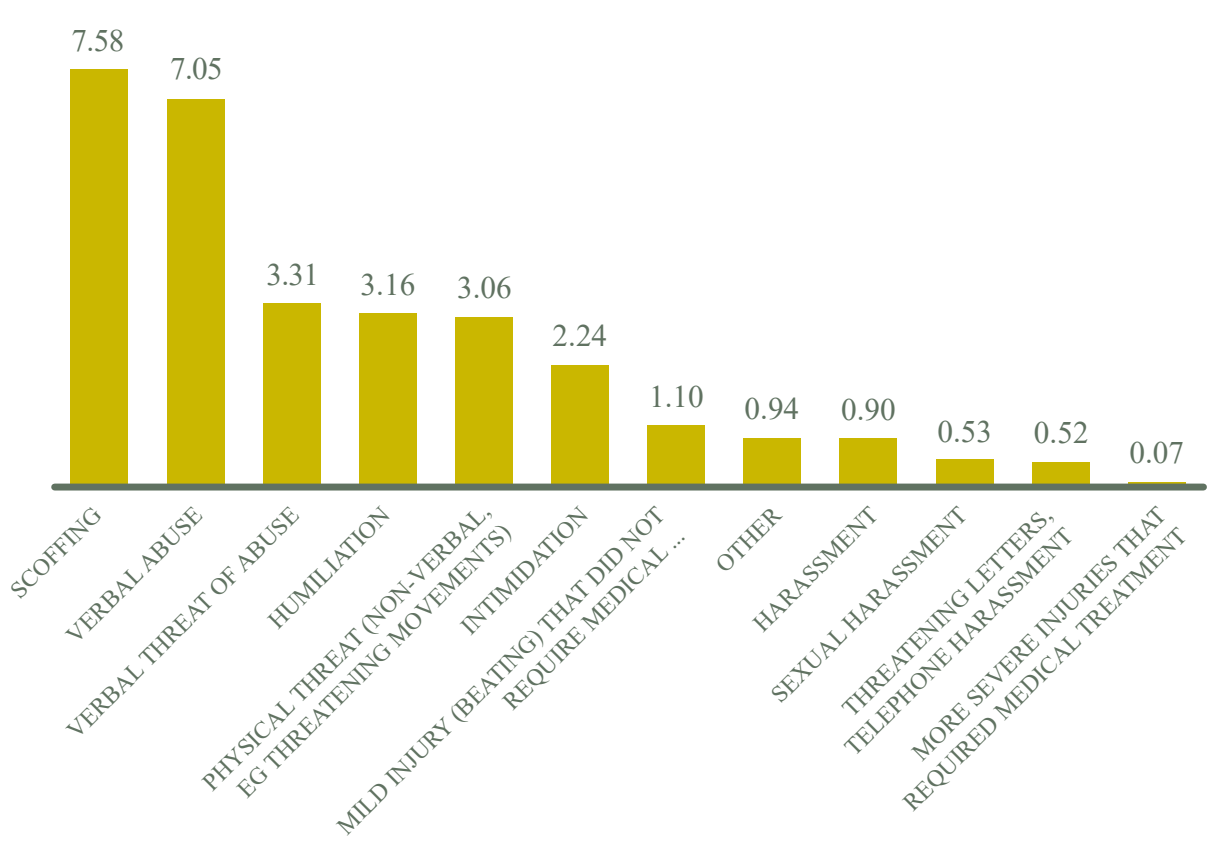

The average incidence of types of aggression induced by relatives also shows significant differences in the forms of verbal aggression (Wilks' $\lambda=0.492 ; \mathrm{F}$ (11; $413)=38.726 ; p<0.001 ; \eta 2=0.508)$. Two forms of verbal violence are much more common than the others (scoffing/teasing, verbal abuse) (Figure 5).

Figure 5:

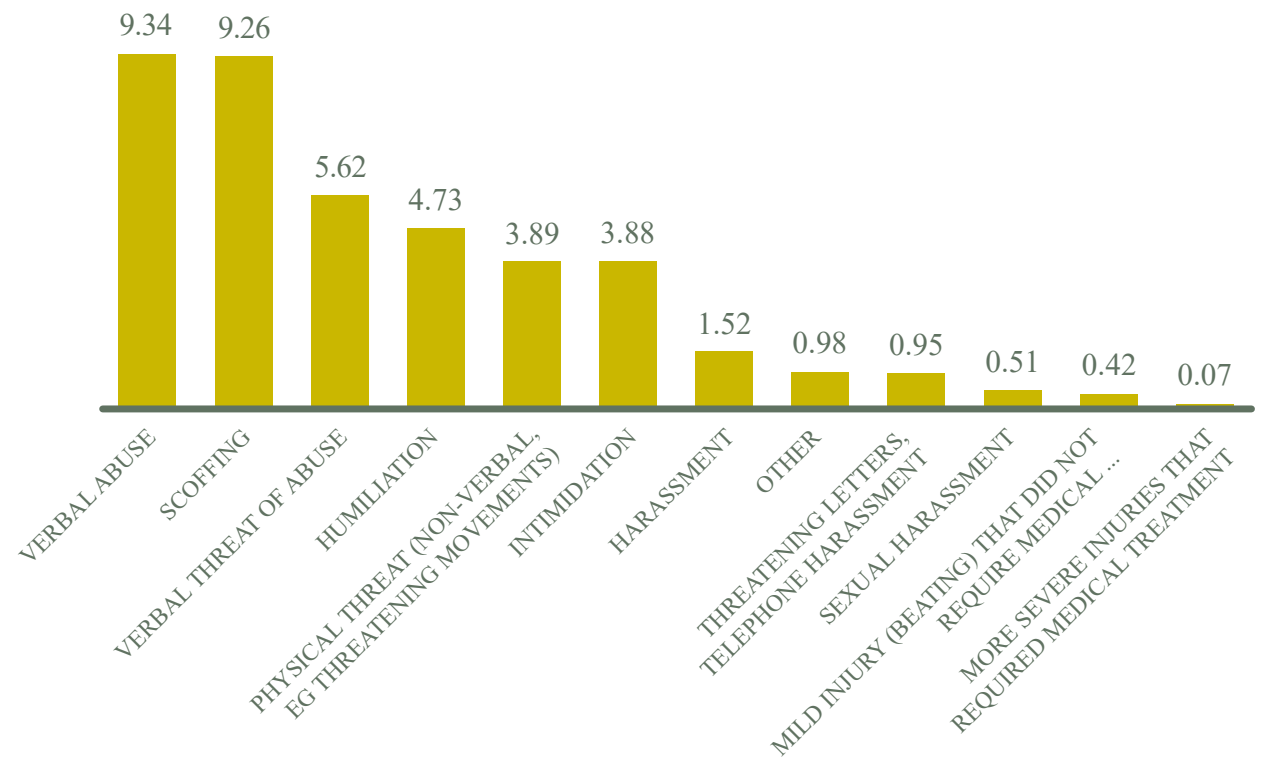


In the past 12 months, the difference of verbal aggression by relatives is also significant (Wilks' $\lambda=0.683 ; \mathrm{F}(11 ; 418)=17.605 \mathrm{~b} ; \mathrm{p}<0.001 ; \eta 2=0.317)$.

The difference in the frequency of forms of verbal violence by colleagues is also significant (Wilks' $\lambda=0.536 ; \mathrm{F}(12 ; 440)=31.762 ; \mathrm{p}<0.001 ; \eta 2=0.464)$. However, in this case, abuse of power and teasing is more common, and humiliation by colleagues also has a higher value on the graph than the forms of aggression committed by patients and relatives (Figure 6).

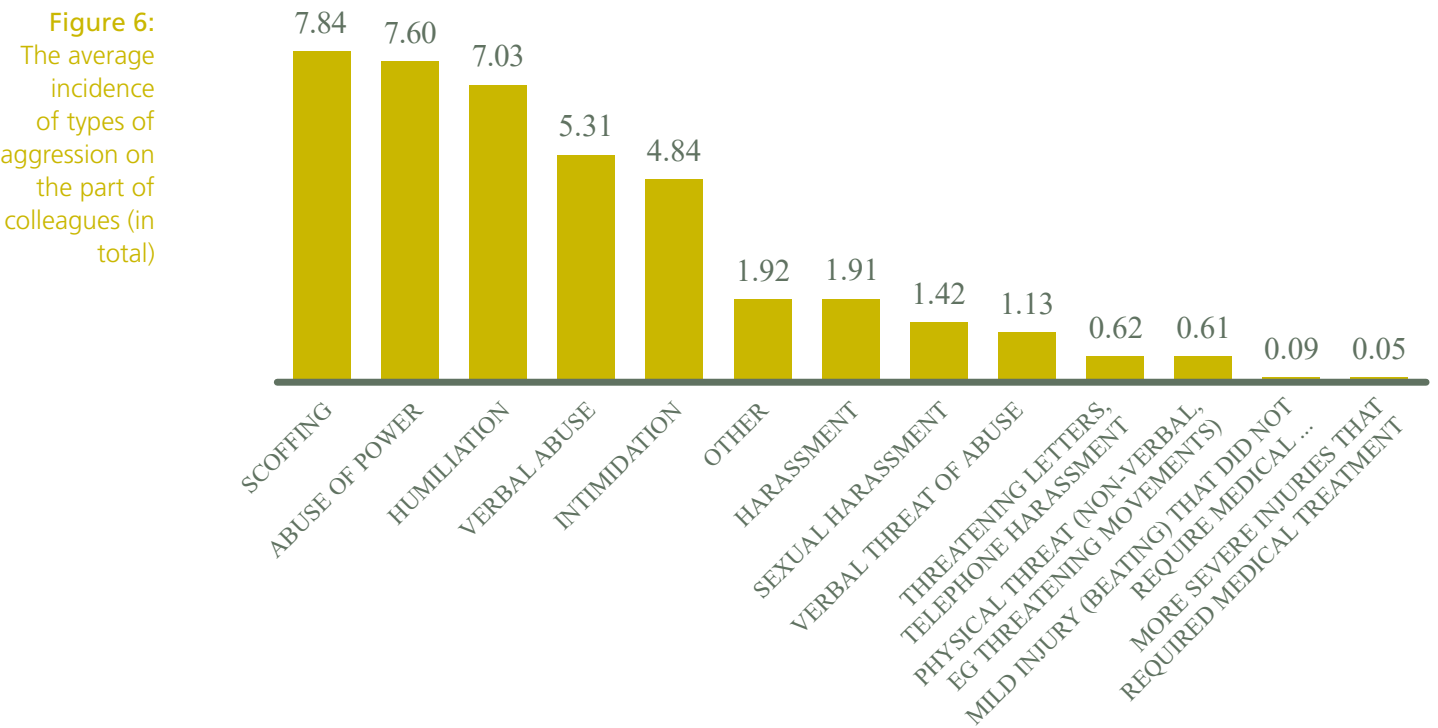

There is also a significant difference in frequency in the year preceding the completion of the questionnaire. (Wilks' $\lambda=0.69$; F $(12 ; 411)=15.404 ; \mathrm{p}<0.001$; $\eta 2=0.310)$. There was almost no abuse or minor injuries suffered by colleagues; however, harassment and sexual harassment was present. There was much less sexual harassment on the part of patients and relatives.

I also examined whether certain forms of violence are more common in outpatient care, such as, for example, specialist clinics, and emergency ambulances. In outpatient care, three groups were made with outpatient clinics, emergency patient care departments (SBO), and the other wards. More aggressive acts were committed by patients and relatives in the outpatient care settings studied. The standard deviation homogeneity condition of the parametric tests for comparing the means was tested by the Levene test, and the results of the corresponding T-test were taken into account on the basis of this result. In some questions, I examined where forms of violence perpetrated by patients and relatives were more common. There was no significant 
difference anywhere with an independent T-test. When comparing different forms of violence in outpatient and non-outpatient settings, I found the following significant differences: forms of violence suffered by patients: verbal threat of abuse, $t$ (65.623) $=-4.281 ; \mathrm{p}=0.001$, physical threat (non-verbal, e.g. threatening physical movements) $\mathrm{t}(65.628)=-2.293 ; \mathrm{p}=0.022$, verbal abuse $\mathrm{t}(63.618)=-3.092: \mathrm{p}=0.030$, teasing $\mathrm{t}$ $(62.614)=-3.384 ; \mathrm{p}=0.001$, threatening letters, telephone harassment outpatient $\mathrm{t}$ $(61.607)=-2.614 ; p=0.010$. In the last 12 months, scoffing/teasing $(63.599)=-2.152$ : $\mathrm{p}=0.035$ was also significant for patients. For relatives, the forms of verbal violence were significant (verbal insult $\mathrm{t}(65.606)=-2.373 ; \mathrm{p}=0.020$, teasing $\mathrm{t}(63.600)=$ -3.314; $\mathrm{p}=0.001$, intimidation $\mathrm{t}(62.584)=-2.9 ; \mathrm{p}=0.02$, humiliation $\mathrm{t}(59.567)=$ $2.309, \mathrm{p}=0.024$. I did not find a significant difference between the forms of violence caused by colleagues and outpatient/non-outpatient settings; forms of violence committed by colleagues can occur in both outpatient and outpatient care. Forms of verbal violence dominate outpatient care the most.

Questions about self-defence training: The following questions were about whether employees had participated in communication, self-defence, and simulation training. When asked how many people took part in the training by the Hungarian Chamber of Healthcare Professionals (hereinafter MESZK), the result was that 90\% (641) of the respondents $(\mathrm{N}=713)$ had not taken part in any MESZK training. Of the 720 respondents, only 58 answered the question What kind of aggression management $M E S Z K$ training did you participate in, and 22 of them did not remember the topic of the training. Only 1 in 20 said they had taken part in MESZK training. Without claiming completeness, MESZK training courses were designated: non-violent communication training; assertive communication training; aggression in healthcare; and communication and aggression management training. The two questions (about MESZK training) were compared by the McNemar test and the difference was significant; a higher proportion had been to non-MESZK courses $(\chi 2(1)=71.141$; $\mathrm{p}<0.001)$.

There were only 433 responses to the question: What other communication or violence prevention training have you attended?; 283 answered 'none', but 150 people had participated in some form of training. We can see that $20-40 \%$ of 433 responses had been on a training course, so there is a demand for it, but not for MESZK training. Again, without claiming completeness, I list a few examples here: communication training; conflict management training; communication training between patients and relatives and colleagues; stress management training; Bálint group; self-development; self-knowledge training; psychodrama; PAF training; and burnout management. A total of 430 people completed both questions (MESZK training, what other communication or violence prevention training have you attended?). Of these, $38 \%$ of respondents had, and $62 \%$ had not, participated in any training course. We can see that the difference is significant; more than half had not had any training. Figure 7 shows who had taken part in training by occupation, and whether it was MESZK training or from another source. It can be seen that nurses, operating room assistants and ambulance nurses were the most likely to have been 
on a training course. Figure 7 also shows how many people did not participate in the MESZK training. There is no interest in the direction of training, which even shows that this training is not considered good, but a deeper examination of this could reveal the exact reasons.

Figure 7: The proportion of participants in training by occupation

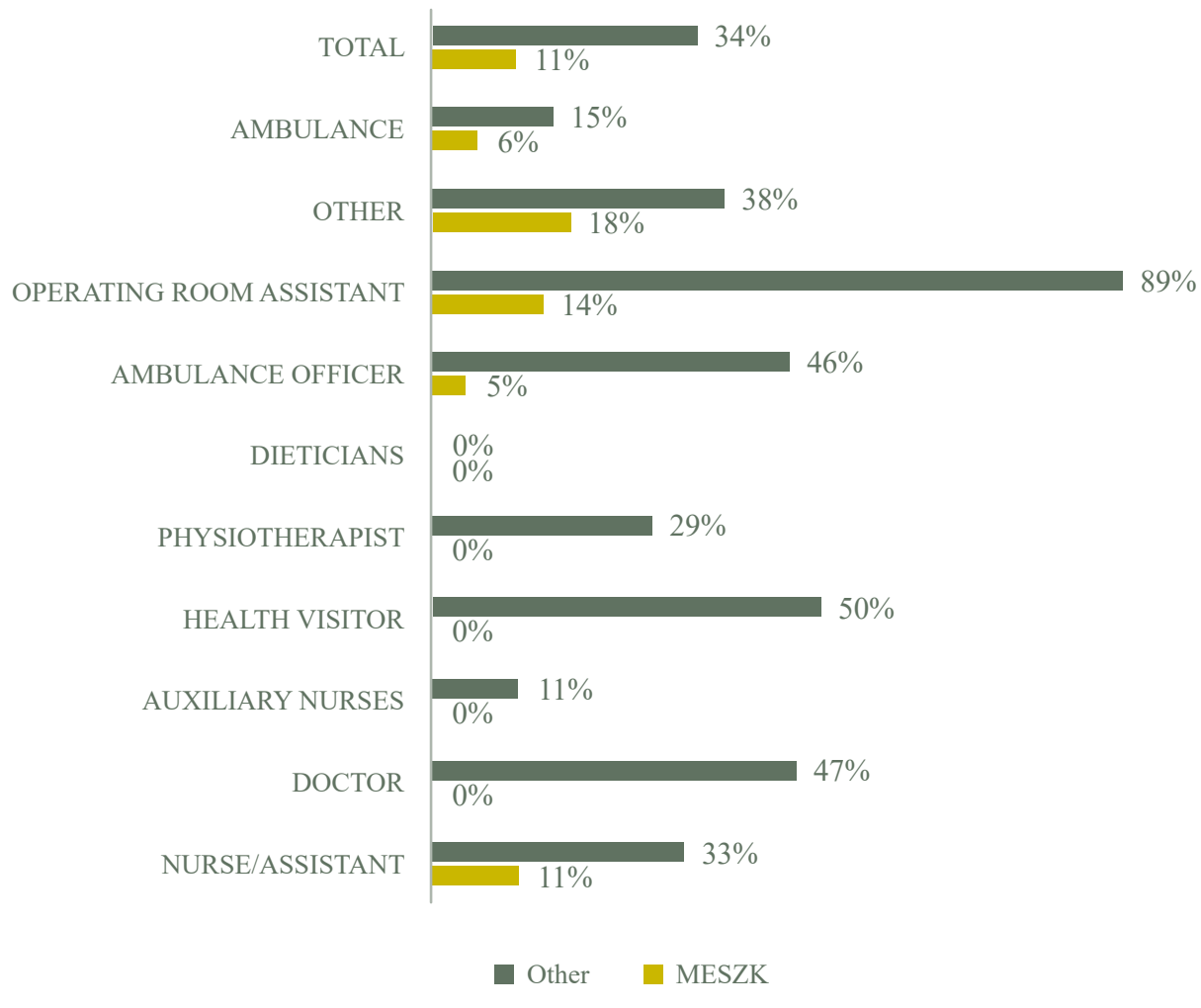

When asked if a simulation exercise had been held in their workplace, only $2 \%$ answered yes. I asked if the training listed above had been held at their workplace, and whether or not they had attended it. According to their answers, 30\% had participated and 70\% had not. The reason given for the lack of participation was that most of them did not know about it. By frequency (89 unanswered, 631 answered) 189 people participated in in-service training (assertive communication training, non-violent communication training, suggestive communication training, communication training), while 345 did not participate because they did not know about it, but might have been interested.

The chart below (Figure 8 ) shows that $70 \%$ of those surveyed had not been to any training. Of these, $3 \%$ were not interested and $12 \%$ had no time, but most of them $(55 \%)$ were unaware that the training was being offered. It follows that it would be 
very useful to advertise this training through several different media, as there is a demand for it.

Figure 8: The proportion of participants in training and reasons for not participating

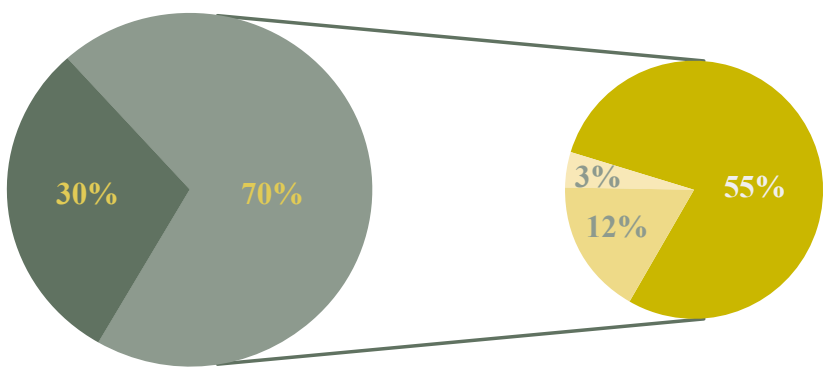

Attended

Lack of time

I didn't care

I didn't know about it

In further questions, I wondered whether the majority of employees required communication, simulation, and self-defence training to help deal with violence. The following questions were asked: Do you think that the use of certain communication training courses would reduce acts of violence? Do you feel it would improve the likelihood of you staying in your career if you could take part in conflict management and violence prevention communication training? Based on the independent sample T-test of the answers to the questions $(\mathrm{t}(426)=-2.15 \mathrm{p}=0.035)$, the respondents thought that violence would decrease as a result of training courses, and the difference was significant, but it would not make a difference to them staying in their profession, which was not significant $(\mathrm{t}(427)=-1.468, \mathrm{p}=0.143)$. The next question was: After completing pre-violence communication training, were the techniques taught there effective during your work? Based on the given answers, although they had attended training course(s), the application of the techniques was not effective in their work $(\mathrm{t}$ $(113)=-0.288, p=0.774)$ as the test was not significant; this may also mean that the current training is not effective enough.

When asked whether a simulation exercise had been held in their workplace, only $2 \%$ said yes. Only 126 people answered how useful it was, based on whether it was effective in their work, because the T-test $(\mathrm{t}(125)=-4.736, \mathrm{p}<0.01)$ showed that the mean of the evaluations of the usefulness of the training (Mean =3.10) was significantly lower than the four-point value what representing the average level, so the average assessment of the usefulness of the training was negative rather than positive.

The questions If you could learn self-defence, how confident would you feel, knowing self-defence techniques? $(\mathrm{N}=387$, Mean = 4.37; Min = 1; Max =7) and How useful would you consider self-defence education to be in the workplace? $(\mathrm{N}=706$, Mean $=$ 4.74; $\operatorname{Min}=1$; Max =7) (Likert attitude scale, 1 to 7, 1 - not really; to 7 - very) were examined by a sample T-test. It can be seen that the average was above 4 , and the 
difference was significant; employees would feel more confident if they could learn self-defence $(\mathrm{t}(386)=3.675 ; \mathrm{p}<0.001)$, and health workers would find self-defence education useful $(\mathrm{t}(705)=9.336 ; \mathrm{p}<0.001)$.

If you have learned self-defence, how much more confident are you knowing selfdefence techniques? was a question on a 1-7 numbered scale (1 - not at all, 7 very much) which averaged 4.41, suggesting that self-defence training gives selfconfidence to the learner. An independent T-test was carried out, and the difference compared to the response marked with 1 , was significant $(\mathrm{t}(179)=22.495 ; \mathrm{p}<0.001)$.

In the question: If you learned self-defence how much you could use it during physical violence? self-defence education was also significant compared to the answer marked 1 with a T-test $(\mathrm{t}(178)=16.410 ; \mathrm{p}<0.001)$, although the average was 3.75 , compared to 1 they were able to use it.

To demonstrate that workers are more confident after pre-violence communication training, and to measure the extent to which workers cope with patient aggression, I measured the degree of confidence (How confident do you feel in the presence of an aggressive patient?) developed by Thackrey. For 10 questions, the answer was selected from a scale of 1-11 (1 - I can't, to 11 - I can). The Cronbach's alpha index was calculated, based on which the scale is reliable $(0.810)$.

Only 177 people answered the question after completing pre-violence communication training, 'Were the techniques taught in the training effective during your work?', while 126 answered the question 'If you participated in a simulation exercise aimed at preventing violence, how effective do you feel what you learned there is in preventing and treating violence?'. These were Likert-like attitude scale questions, answered on a scale from 1 to 7 (1- not really, 7 - very) (see Table 3 for details).

\begin{tabular}{|c|c|c|c|c|c|c|c|c|c|c|c|}
\hline \multirow{2}{*}{$\begin{array}{r}\text { Table 3: } \\
\text { Changes in } \\
\text { the level of } \\
\text { confidence and }\end{array}$} & \multirow{2}{*}{$\begin{array}{l}\text { Training/ } \\
\text { Education }\end{array}$} & \multicolumn{3}{|l|}{ No } & \multicolumn{3}{|l|}{ Yes } & \multicolumn{2}{|c|}{ Levene-test } & \multicolumn{2}{|c|}{ T-test (2-side)* } \\
\hline & & Capita & M & SD & Capita & M & SD & $F$ & $\mathbf{p}$ & $\mathbf{t}$ & $p$ \\
\hline $\begin{array}{l}\text { test statistics as } \\
\text { a function of } \\
\text { participation in } \\
\text { different types }\end{array}$ & $\begin{array}{l}\text { Have you } \\
\text { learned } \\
\text { self-defence? }\end{array}$ & 540 & 5.898 & 1.935 & 179 & 6.765 & 1.676 & 4.755 & 0.030 & -5.763 & $<0.001$ \\
\hline $\begin{array}{l}\text { of training. }{ }^{*} \mid \\
\text { have reported } \\
\text { the results }\end{array}$ & $\begin{array}{l}\text { Communication } \\
\text { training }\end{array}$ & 542 & 6.030 & 1.907 & 177 & 6.371 & 1.900 & 0.686 & 0.408 & -2.066 & 0.039 \\
\hline $\begin{array}{l}\text { of the l-test } \\
\text { corresponding } \\
\text { to the Levene }\end{array}$ & $\begin{array}{l}\text { Simulation } \\
\text { exercise }\end{array}$ & 593 & 5.989 & 1.907 & 126 & 6.701 & 1.820 & 0.397 & 0.529 & -3.838 & $<0.001$ \\
\hline
\end{tabular}


I compared how the respondents' confidence developed as a function of training, whether they did not participate in any type of training, or whether they participated in only one, two, or all three types of training courses. The level of confidence differed significantly depending on participation in the courses (Levene: $\mathrm{F}(7 ; 711)$ $=1.707 ; \mathrm{p}=0.104$; ANOVA: F $(7 ; 711)=6.941 ; \mathrm{p} 0.001)$. Pairwise differences were examined by Bonferroni's post hoc test, which in several cases was probably not significant due to the low number of group items (see Table 4).

Table 4: Descriptive statistics of confidence based on participation in training

(the letters are intended to indicate

significant/ non-significant differences, such as: $a=a b, b=$ $a b, a \neq b)$

\begin{tabular}{|l|c|c|c|}
\hline \multicolumn{1}{|c|}{ Training/Education } & N & M & SD \\
\hline Did not participate in anything (a) & 348 & 5.692 & 1.932 \\
\hline Communication training only (ab) & 106 & 6.107 & 1.928 \\
\hline Simulation exercise only (b) & 62 & 6.514 & 1.972 \\
\hline Self-defence only (b) & 109 & 6.671 & 1.563 \\
\hline Communication + simulation (ab) & 24 & 6.367 & 1.429 \\
\hline Self-defence + communication (ab) & 30 & 6.537 & 1.958 \\
\hline Self-defence + simulation (ab) & 23 & 6.796 & 1.644 \\
\hline All three (b) & 17 & 7.728 & 1.725 \\
\hline Together & 719 & 6.114 & 1.910 \\
\hline
\end{tabular}

Based on the means and tests, we can see that those who did not have any training/ education have the lowest confidence. This result alone confirms the role of training in increasing confidence. The trend is positive, meaning that the more training people have, the more confident they are (Figure 9).

Figure 9:

The relation between training and confidence (mean value)
ALL THREE (B)

SELF DEFENCE+SIMULATION (AB)

ONLY SELF DEFENCE TRAINING (B)

ALL SELF DEFENCE+COMMUNICATION (AB)

ONLY SIMULATION EXERCISE (B)

COMMUNICATION+SIMULATION (AB)

ONLY COMMUNICATION TRAINING (AB)

NOTHING WAS INVOLVED (A)

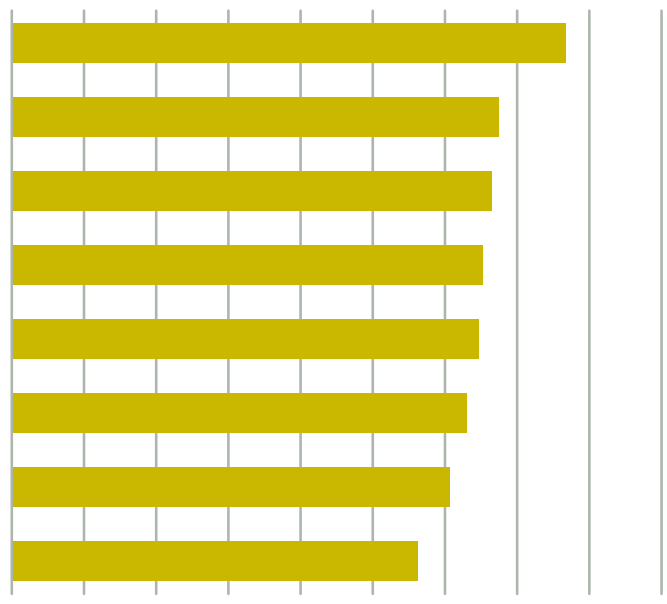


Only $2 \%$ of the sample participated in all three types of training $(\mathrm{N}=719)$. Based on the pie chart in Figure 10, we can see the percentage of participants in each type of training. It can be seen that almost half of the respondents $(49 \%)$ did not participate in any training.

Figure 10: The proportion of participants in training

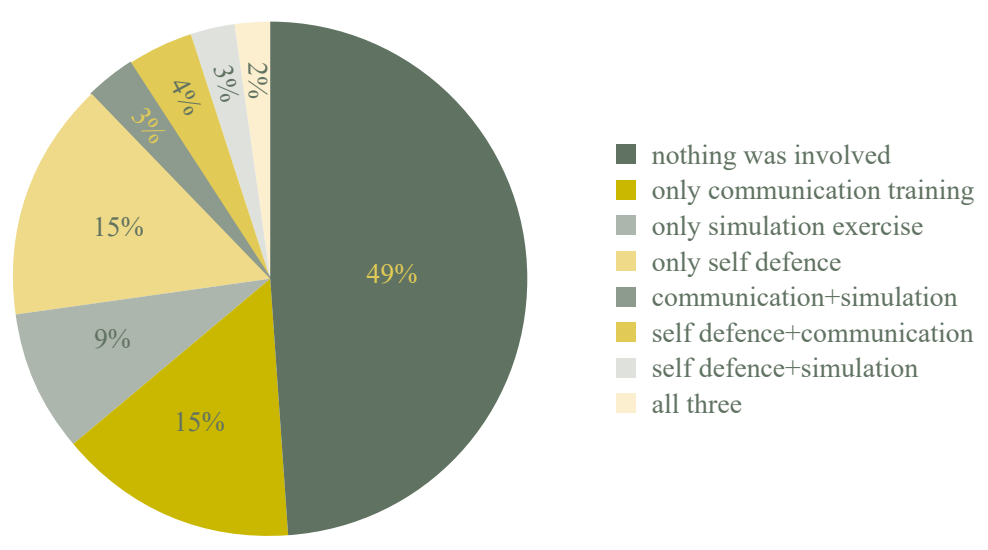

I hypothesized that the more confident a healthcare worker is, the fewer violent acts they will encounter. If a healthcare professional had attended even just one training course, their confidence increased significantly (Levene: $F(2 ; 716)=1.499 ; p=0.221$; t-test: $\mathrm{t}(717)=-4.209 ; \mathrm{p}<0.001)$. However, unfortunately there was no significant change in the number of violent events (Levene: $F(2 ; 419)=6.404 ; p=0.012$; t-test: $t(328,332)=1.025 ; p=0.306)$. Examining the correlation between the number of types of training the healthcare worker received (maximum three: communication, situational, self-defence) and whether this affected the number of atrocities they experienced and their level of self-confidence, the number of violent events did not correlate with the number of types of training $(r=-0.051 ; p=0.300)$, but it did with the level of confidence $(r=0.199 ; p<0.001)$. Statistics also underline that the more training someone has, the more confident they feel.

\section{DISCUSSION}

In the foregoing description, I have presented some of my empirical research, but for reasons of length I have not detailed the entire quantitative research. I was looking for an answer to the question of which forms of violence occur in Hungarian healthcare, which are the most common ones, and when and where they occur.

According to the research, there are many more acts of violence during the day, and the most common location is the ward or waiting room. It can be stated that when an atrocity affects a healthcare worker, they turn to their colleagues during the violent 
incident, and afterwards ask the head nurse or psychologist for help in processing the issue.

Based on statistical tests, the verbal threat of abuse, physical threats (non-verbal, e.g. threatening physical movements), verbal abuse, scoffing/teasing, threatening letters, telephone harassment, humiliation, and intimidation are more common in outpatient care. In outpatient wards, the healthcare worker is more exposed to violence regardless of whether it is from a patient or a relative. Verbal atrocities affect them more often.

The application of individual communication training would reduce violence, as based on the answers to the question there is a significant difference. According to those who attended a training course the number of violence events would decrease, and they think there is a need for training; they found it useful and they would attend it. Those who have ever been on any training course agree that training reduces violence. Those who learned self-defence became more confident, and those who did not would also find it useful and it would increase their confidence. The fact that 3.75 was the average response to using self-defence in their work does not show that it was not useful to learn self-defence, but that they did not have the opportunity to use it; possibly due to proper prevention, physically violent events did not occur.

Based on the data, we can also see that communication training alone is not enough to make health workers confident. They should have a tool in their hands, e.g. practice after self-defence education, or simulation (role play) practice, as this makes it easier for the employee to communicate. The results obtained may also signal that communication training is necessary but not sufficient in itself; it should be followed by simulation practice as well as self-defence training and practice.

Participation in other communication or violence prevention training increases the confidence of healthcare workers, but communication alone does not. However, participation in this training does not significantly reduce the average number of violent events experienced in a year.

I was also curious about the qualitative part of the research, so the last question was an open-ended one, asking the respondents for suggestions on violence prevention. However, based on the answers to this question, the health workers expect the aggression solution to come mostly from outside help. I divided the answers into 9 groups. The most frequently mentioned suggestions are: conducting communication training, external protection, more security guards, improving working conditions, a self-defence course, and appropriate behaviour on the part of employees. In a psychiatric ward, where verbal and physical forms of violence are commonplace, it can be helpful if the worker can defend themselves not only verbally. 
Conclusion It is a societal expectation that a healthcare worker should do everything in their power to protect the often immobile and indecisive patient. Also, according to the Hippocratic oath, it is the duty not only of a doctor, but also of nurses, to do their utmost to protect patients. However, this also applies to healthcare professionals' physical integrity, as everyone has a subjective right to self-defence. If a worker is injured in a conflict or fire, there will be no one to protect or save the patients. In addition to fire education, self-defence training should also be important and mandatory, especially for those working in wards where they are increasingly exposed to patient aggression (Emergency Care Department - SBO, psychiatric ward, psychiatric outpatient clinic). According to the present research, there is a need for such training for workers; they also undertook training $(25.2 \%$ of them trained in self-defence) but they could only do this at their own expense.

The number of acts of violence in societies is growing, and institution leaders are increasingly recognizing that healthcare workers, and even patients, are at risk. Workers who have received adequate self-defence training are less likely to be attacked and suffer less serious injuries if they are attacked (Temple, 1994, p 281).

Healthcare workers can only exert a reasonable force in self-defence, although the usual response to possible violence should be to prevent it or, if possible, to escape from the situation. Educating staff on de-escalation and active listening techniques should include practice in simulated scenarios. These classes should focus on defensive skills related to de-escalation, protection, and escape, rather than the offensive techniques taught in self-defence courses. Basic self-defence courses are not adequate for a clinical setting, as the staff need a long course of training ${ }^{8}$ (Gillespie, Gates, Howard, 2010, p 177). The healthcare aggression situation has become so bad that more and more articles and books are suggesting that healthcare professionals should learn martial arts for self-defence, which would also boost their confidence even if they are never used (HAM Nazmul, Aparna, 2014, p 106, Privitera, 2011, p 332).

Several authors have written about how self-defence training increases the confidence of health workers, as the present research supports. Statistically significant increases in confidence, safety in working with aggressive patients, and confidence levels for safe breakaways have been reported. Qualitative comments demonstrated a desire for ongoing skills workshops (Lamont, S., Brunero, S., Bailey, A., \& Woods 2012, p 313). Another study found that in the UK, $60 \%$ of health workers were able to use self-defence techniques after training (Rogers, P., Ghroum, P., Benson, R., Forward, L., \& Gournay, 2006, p 593). However, other articles concluded that either there was no good self-defence training, or it only lasted for a short time so it was not used

\footnotetext{
»Protective strategies for combating the negative consequences of workplace violence include carrying a telephone, practicing self-defence, instructing perpetrators to stop being violent, self-and social support, and limiting interactions with potential or known perpetrators of violence. « From: Gillespie, G. L., Gates, D. M., Miller, M., \& Howard, P. K.., 2010, pp 177-184.
} 
effectively by the workers (Dickens, G., Rogers, G., Rooney, c., Mc Guinness, A., \& Doyle 2009, p 777).

Every person has the right to defend themselves against an aggressor. However, the reaction must be proportionate to the actions of the aggressor (Dimond, 2011). Self-defence should be the last resort; where attacks are reasonably foreseeable, employers should ensure that security measures are in place to protect staff. However, if this is not enough, workers must protect themselves and their patients' physical integrity in every possible manner. But the greatest preventive tool is to give respect to each other, and to respect human dignity. Adequate treatment (medication and physical limitation) of patients with symptoms that are prone to brain depression is of paramount importance.

It should also be taken into account that $70-80 \%$ of employees in healthcare institutions are female, and thus may be more likely to be victims of verbal and non-verbal violence, and even sexual harassment. It is also characteristic that women are more likely to cause verbal violence, while men are more likely to cause physical violence. Verbal violence is much more common in healthcare than physical violence, but both can be prevented through effective communication (Deák, 2012, p.185). However, if this is not enough, self-defence may also be needed. It can be especially helpful for women to be able to protect themselves in physical and sexually violent events.

Based on the results of the research, I propose a plan for the management of violence against medical staff, consisting of the following steps:

1. Prevention: facility risk assessment, facility-specific risk assessment, security plans, emergency action plans, theoretical and communication training, deescalation methods, simulation exercises.

2. Things to do during violence: appointing people to whom you can turn for help, holding self-defence training.

3. After violence: reporting obligations, psychologist, support groups, employee post-incident debriefing and monitoring, testing of theoretical knowledge. The facilities' security systems and people must have the proper knowledge and equipment to protect against external and internal threats.

1. American Nursing Association (ANA) 2019. Passage of workplace violence prevention legislation, https://www.nursingworld.org/news/news-releases/2019-news-releases/anaapplauds-passage-of-workplace-violence-prevention-legislation/ <15. 6. 2020>.

2. Arnetz, J. E., Arnetz, B. B., \& Petterson, I.-L., 1996. Violence in the nursing profession: occupational and lifestyle risk factors in Swedish nurses. Work \& Stress, 1996, 10(2), pp 119-127. DOI:10.1080/02678379608256791.

3. Besenyö J., Kármán M., 2020. Effects of the COVID-19 pandemic on African health, political and economic strategy. Insights into Regional Development, Entrepreneurship and Sustainability Center, 2(3), pp 630-644. 
4. Besenyö, J., Deák G., 2010. A biztonság új aspektusai. A kórházi személyzet biztonsága - a kórházi eröszakos cselekedetek megelözése. (New aspects of security. Safety of hospital staff - prevention of hospital violence). Székesfehérvár, MH Összhaderönemi Parancsnokság Tudományos Tanács, 2010. ISBN 978-963-06-9219-9.

5. Besenyö, J., Márton, K., Shaffer, R., 2021. Hospital Attacks Since 9/11: An Analysis of Terrorism Targeting Healthcare Facilities and Workers, Studies in Conflict \& Terrorism. 2021, pp 1-19. DOI: 10.1080/1057610X.2021.1937821.

6. Boaz, G., Miri H., Wernli, 2013. Terrorist Attacks against Hospitals: Case Studies, Working Paper no. 25, Herzliya: International Institute for Counter-Terrorism. $p 4$.

7. Bugala, M., Reguli Z., Michal Vit, M., Cihounkova, J., 2016. Evaluation of self-defence training in the Czech Emergency Medical Service, "Ido movement for culture«. Journal of Martial Arts Anthropology«, Vol. 16, No. 1, pp 49-54.

8. Deák, G., 2011. Are Hungarian hospitals able to manage terror acts, bomb threats? Tradecraft review, Periodical of the Scientific Board of Military Security Office Special issue, 2011, 1, pp 29-133.

9. Deák, G., 2012. Eröszak a kórházban (Violence in the hospital) n: Military Security Office, Professional Review, 2012/1 Budapest. pp 180-189.

10. Deák, G., 2011. Hospital security - preventing and managing workplace violence in healthcare sector. AARMS, 2011, 10(1), pp 161-171.

11. Dickens, G., Rogers, G., Rooney, C., Mc Guinness, A., \& Doyle, D., 2009. An audit of the use of breakaway techniques in a large psychiatric hospital: a replication study. Journal of Psychiatric and Mental Health Nursing, (2009), 16(9), pp 777-783. DOI: 10.1111/j.1365-2850.2009.01449.x.

12. Dimond, B., 2011. Legal Issues Violence in the workplace and towards the midwife Published British Journal of Midwifery Vol. 11, No. 11, ENYÜBSZ dokumentum. https:// bsr.bm.hu/Document $<20$. 6. 2021>.

13. Gillespie, G. L., Gates, D. M., Miller, M., \& Howard, P. K., 2010. Workplace Violence in Healthcare Settings: Risk Factors and Protective Strategies. Rehabilitation Nursing, (2010), 35(5), 177-184. DOI: 10.1002/j.2048-7940.2010.tb00045.x.

14. HAM Nazmul A., Aparna D., 2014. Violence against doctors. J. Medicine. 15, pp 106108. DOI: 10.3329/jom.v1li2.5465.

15. Henson, B., 2010. Preventing Interpersonal Violence in Emergency Departments: Practical Applications of Criminology Theory. Violence and Victims, 25(4), pp 553-565. DOI: $10.1891 / 0886-6708.25 .4 .553$.

16. Irinyi T., 2018. Összefüggések az egészségügyi szakdolgozói kiégettség, az általuk elszenvedett agresszió gyakorisága és a munkahelyi konfliktusaik között, Doktori (PhD) értekezés, Pécsi tudományegyetem egészségtudományi kar egészségtudományi doktori iskola, 2018.

17. Irinyi T., Németh A., 2016. Egészségügyi dolgozók ellen elkövetett agresszív cselekmények, Orvosi Hetilap 157(28), 1105-1109.

18. Irinyi T., Németh A., Lampek, K., 2017. Az egészségügyi szakdolgozókat ért agresszív cselekmények kapcsolata szociodemográfiai és munkahelyi tényezökkel (Violence against healthcare providers and its correlations with sociodemographic and workplace-related factors) Orvosi Hetilap 158(6), pp 229-237.

19. Ivánka, T., Irinyi, T., Rudisch, T., 2014. Agresszió megelözését célzó továbbképzés egészségügyi szakdolgozók körében. (Aggression management programme for healthcare workers.) Növér, 2014, 27(4), pp 11-17.

20. Ivánka, T., Irinyi, T., Rudisch, T., 2014. Agresszív cselekmények elö fordulásának vizsgálata egészségügyi szakdolgozók körében. (Occurrences involving aggression among healthcare workers) Növér, 2014, 27(2), pp 19-25. 
21. Lamont, S., Brunero, S., Bailey, A., \& Woods, K., 2012. Breakaway technique training as a means of increasing confidence in managing aggression in neuroscience nursing. Australian Health Review, 2012, 36(3), p. 313. DOI: 10.1071/ah11001.

22. Lövöldözés egy ostravai kórházban: https://www.origo.hu/nagyvilag/20191210lovoldozes-egy-ostravai-korhazban-tobben-meghaltak.html, <6. 6. 2021>.

23. Pinar, T., Acikel, C., Pinar, G., Karabulut, E., Saygun, M., Bariskin, E., Cengiz, M., 2017. Workplace Violence in the Health Sector in Turkey: A National Study. Journal of Interpersonal Violence, 32(15), pp 2345-2365. DOI: https://doi. org/10.1177/088626051559.

24. Privitera, M., R., 2011. Workplace Violence In. Mental And General Health Settings, Publisher: Jones \& Barlett Learning, Paperback, p. 332. ISBN: 9780763779344.

25. Honvéd Kórházi késelés: https://ripost.hu/politik/insider/korhazi-keseles-kegyetlenreszletek-honvedkorhaz-2804572/, <6. 4. 2021>.

26. Ráczkevy-Deák, G., 2020. Hospital Security: Hospitals and Terrorism. (Kórházak biztonsága: kórházak és terrorizmus). Belügyi Szemle, 68(2), pp 87-98. https://doi. org/10.38146/BSZ.SPEC, <6. 2. 2020>.

27. Rogers, P., Ghroum, P., Benson, R., Forward, L., \& Gournay, K., 2006. Is breakaway training effective? An audit of one medium secure unit. Journal of Forensic Psychiatry \& Psychology, 17(4), pp 593-602. DOI: 10.1080/14789940600893056.

28. Sharipova, M., Borg, V., \& Hogh, 2008. The prevalence, seriousness, and reporting of work-related violence in Danish elderly care. Scandinavian Journal of Caring Sciences, 22(4), pp 574-581.

29. Temple, C. M., 1994. Managing Physical Assault in a Healthcare Setting. Rehabilitation Nursing, (1994). 19(5), pp 281-286. DOI: 10.1002/j.2048-7940.1994.tb00823.x .

30. Thackrey, M., 1987. Clinician confidence in coping with patient aggression: Assessment and enhancement. (1987). Professional Psychology: Research and Practice, 18(1), pp 57-60. DOI: 10.1037/0735-7028.18.1.57.

31. Vérfürdö egy romániai pszichiátrián http://medicalonline.hu/kitekinto/cikk/verfurdo_egy_ romaniai_pszichiatrian, <6. 6. 2021>.

32. World Health Organisation. 2008. Spotlight on Statistics. A Fact File on Health Workforce Statistics. Retrieved 3. 11. 2020, from the World Health Organisation: https://www.who. int/hrh/statistics/spotlight_2.pdf, <1. 7.2021>.

33. Yudofsky, S.C., Silver, J.M., Jackson, W., Endicott, J., Williams, D., 1986. The Overt Aggression Scale for the objective rating of verbal and physical aggression. (1986). American Journal of Psychiatry, 143(1), pp 35-39. DOI: 10.1176/ajp.143.1.3. 


\section{KULTURNA DEDIŠČINA IN NJENO VAROVANJE V ČASU OBOROŽENIH SPOPADOV}

Povzetek Kulturna dediščina oziroma kulturne dobrine so izraz zgodovinske tradicije nekega naroda. V zgodovini vojskovanja je bila kulturna dediščina pogosto uničena, poškodovana in izropana. Prispevek predstavlja zgodovinski razvoj mednarodnopravne zaščite kulturnih dobrin, obveznosti, ki jih imajo visoke pogodbenice Konvencije o varstvu kulturnih dobrin v primeru oboroženega spopada, nekatera najpomembnejša pravila glede varovanja kulturnih dobrin med oboroženimi spopadi, slovensko delovanje na obravnavanem področju ter pozitivne in negativne posledice (ne)varovanja kulturnih dobrin.

Ključne Varovanje kulturnih dobrin, oboroženi spopadi, Haaška konvencija.

besede

Abstract Cultural heritage and cultural property are an expression of the historical tradition of a certain nation. Throughout the history of warfare, cultural heritage has often been destroyed, damaged and looted. The article presents the historical development of international legal protection of cultural property, the obligations of the High Contracting Parties to the Convention for the Protection of Cultural Property in the Event of Armed Conflict, some of the most important rules regarding the protection of cultural property in armed conflicts, Slovenian activities in this field, and the positive and negative consequences of the (non-) protection of cultural property.

Protection of cultural property, armed conflicts, Hague Convention. 
Uvod Kulturna dediščina so dobrine, podedovane iz preteklosti, ki jih posamezniki opredeljujejo kot odsev in izraz svojih vrednot, identitet, verskih in drugih prepričanj, znanja in tradicije. Vključuje vidike okolja, ki izhajajo iz medsebojnega vplivanja med ljudmi in prostorom skozi čas. ${ }^{1}$

Izkušnje kažejo, da kultura in kulturna dediščina igrata pomembno vlogo v modernih oboroženih spopadih. Praktično v živo smo lahko spremljali uničenje Starega mostu čez reko Neretvo v Mostarju, bombardiranje starega dubrovniškega mestnega jedra, uničenje antične Palmire ali znamenitih kipov bud iz Bamijana. Uničenje dediščine lahko pretrga povezave s preteklostjo in izbriše identiteto posameznega naroda iz zgodovinskega spomina.

Kar danes poimenujemo kot kulturna dobrina ${ }^{2}$, je imelo pomembno vlogo med oboroženimi spopadi od najstarejših časov dalje. Plenjenje je bil pogosto najpomembnejši cilj vojne. Že v Pravilih vojne, ki jih najdemo v 5. Mojzesovi knjigi, je zapisano: »Le ženske, otroke, živino in vse, kar je v mestu, ves plen v njem zapleni zase in uživaj plen svojih sovražnikov, ki ti ga da GOSPOD, tvoj Bog! (Sveto pismo, 2016, str. 210). Način vojskovanja, ki je bil povezan s plenjenjem in ropanjem, pa tudi uničevanjem vsega, kar je pripadalo nasprotniku, se je do konca uveljavil med rimskimi osvajanji vsega takrat znanega sveta (Jogan, 2008, str. 15). V času prve judovsko-rimske vojne, ki je potekala med letoma 66 in 73, so rimske vojaške enote pod poveljstvom poznejšega cesarja Tita Flavija uničile velik del Jeruzalema in tempelj. Po Titovi smrti je bil v spomin nanj v Rimu zgrajen Titov slavolok, na katerem so upodobljeni vojaki, ki odnašajo plen izjeruzalemskega templja. Postavitev rimskega Koloseja je bila financirana s plenom, pridobljenim v tej vojni (Turku, 2018, str. 33). Med Napoleonovimi osvajanji je potekalo sistematično plenjenje umetniških del premaganih držav. Tudi v novejšem času so bili naši predniki priče uničenju kulturne dediščine. Med drugo svetovno vojno uničeni samostan Monte Cassino predstavlja simbol uničenja kulturnih dobrin med oboroženim spopadom.

\footnotetext{
Povzeto po definiciji dediščine iz drugega odstavka prvega člena Zakona o varstvu kulturne dediščine (ZKVD1), ki je bil sprejet 1. 2. 2008. Konvencija o varstvu kulturnih dobrin v primeru oboroženega spopada uporablja termin kulturne dobrine. Konvencija šteje za kulturne dobrine:

a) premičnine ali nepremičnine, ki so pomembne za kulturno dediščino vsakega naroda, kot so arhitekturni, umetnostni ali zgodovinski spomeniki, verski ali posvetni spomeniki, arheološka območja, skupine zgradb, ki so kot celote zgodovinsko ali umetnostno zanimive, umetnine, rokopisi, knjige in drugi umetnostno, zgodovinsko ali arheološko zanimivi predmeti ter znanstvene zbirke in pomembne zbirke knjig, arhivov ali reprodukcije prej naštetih del;

b) stavbe, katerih poglavitni in stvarni namen je, da varujejo ali razstavljajo premične kulturne dobrine, opredeljene v odstavku a), kot so muzeji, velike knjižnice, arhivska skladišča in tudi zaklonišča, namenjena zavarovanju v odstavku a) opredeljenih premičnih kulturnih dobrin ob oboroženem spopadu;

c) središča, v katerih je znatno število kulturnih dobrin, ki so navedena vodstavkih a) in b), tako imenovana spomeniška središča.

2 Konvencija o varstvu kulturnih dobrin v primeru oboroženega spopada uporablja termin »kulturne dobrine«, zato je ta termin uporabljen tudi v prispevku.
} 


\section{RAZVOJ MEDNARODNOPRAVNEGA VARSTVA KULTURNIH DOBRIN}

Stoletja dolgo je veljalo, da so dovoljena vsa sredstva za dosego cilja, dokler je cilj vojne pravičen. Vsa lastnina nasprotnika je lahko bila uničena, če je to pripomoglo $\mathrm{k}$ vojaški zmagi. Kot neke vrste začetek sistema varstva kulturnih dobrin lahko štejemo določilo delfske zveze starogrških držav iz leta 1100 pred našim štetjem, ki prepoveduje rušenje mest do njihovih temeljev (Kladnik, 2010, str. 180). V času rimskega imperija so posamezniki opozarjali na nesmiselno uničevanje kulturnih dobrin. Rimski državnik, pravnik, politični teoretik in filozof Cicero je svetoval, da se cilji vojne prilagodijo zakonu tako, da se upošteva zmernost pri plenitvi (Jogan, 2008, str. 15). V 16. stoletju so se začele pojavljati zamisli, da spomeniki in umetniška dela predstavljajo posebno kategorijo lastnine, ki jo je med vojno treba zaščititi. Nekateri teoretiki mednarodnega prava so menili, da uničevanje kulturnih objektov skoraj nikoli ni upravičevalo vojaškega cilja. Verjetno najbolj konkreten v tem razmišljanju je bil Emer de Vattel, ki je v svojem delu Le Droit des Gens, ou Principes de la Loi Naturelle zapisal, da ne glede na razloge, zaradi katerih napadalec opustoši državo, mora prizanesti zgradbam, ki slavijo človeka in ki ne pripomorejo k sovražnikovi moči, kot so templji, grobnice, javne zgradbe in druga umetniška dela. Le zagrizen sovražnik človeštva lahko ljudi prikrajša za takšne spomenike (O`Keefe, 2006, str. 11). Nihče izmed razsvetljenskih mislecev pa še ni razvil posebne misli, namenjene zaplembi nasprotnikovega premoženja, do katerega je imel po veljavnem mednarodnem pravu zmagovalec vso pravico.

Francoska revolucija in napoleonske vojne, ki so ji sledile, predstavljajo prelomnico $\mathrm{v}$ pravni zaščiti spomenikov in umetniških predmetov. Močne strasti, ki jih je razvnela francoska revolucija, so predstavljale veliko nevarnost za umetniška dela na francoskih tleh. Leta 1790 je bila ustanovljena posebna komisija, ki je prevzela skrb nad zaplenjeno kulturno dediščino plemstva, Cerkve in francoskih emigrantov, dediščino, kije bila od takrat naprej last vseh (O`Keefe, 2006, str. 13-14). Tudi nekoliko pozneje izdani dekreti, ki so opredeljevali uničenje ostankov predrevolucionarnega despotizma, so kot izjeme predvidevali umetniška dela velike vrednosti. Zunaj Francije pa je Napoleonova osvajanja spremljalo sistematično plenjenje umetniških del premaganih držav. Francoska država je deloma s silo deloma pa z izsiljenimi pogodbami napolnila Museé Central des Arts (Senković, 2013, str. 4). Inspiracija za ta dejanja je bila vizija panevropske kulture, katere najprimernejši skrbnik bi bila Francija, republika med tiranijami. Po Napoleonovem padcu je bila Franciji ukazana vrnitev zaplenjenih del.

Medtem pa je na drugem koncu Atlantika novo načelo, da so umetniška dela del skupne dediščine človeštva in da kot taka uživajo poseben status, dobilo potrditev v sodbi britanskega pomorskega sodišča v Novi Škotski. Sodišče je ukazalo vrnitev umetniških del, ki jih je angleška mornarica zaplenila med anglo-ameriško vojno leta 1812 (O`Keefe, 2006, str. 15). 


\subsection{Lieberjev kodeks}

Prva kodifikacija vojnega prava, Generalni ukaz št. 100 oz. Lieberjev kodeks, ki ga je predsednik Lincoln izdal med ameriško državljansko vojno, vsebuje tudi prva pravila, namenjena varovanju kulturnih dobrin. V 35. členu kodeksa je zapisano, da morajo biti klasična umetniška dela, knjižnice, znanstvene zbirke ali dragoceni inštrumenti in tudi bolnišnice, zaščiteni tudi takrat, če so v utrjenih mestih med obleganjem ali bombardiranjem (Instructions for the Government of Armies of the United states in the Field, člen 35, 1863). Lieberjev kodeks je vplival na Bruseljsko deklaracijo iz leta 1874 in na Oxfordski priročnik iz leta 1880, ki sta prepovedovala uničenje nasprotnikove lastnine, če to ni zahtevala vojaška nujnost.

\subsection{Druga (1899) in Četrta (1907) Haaška konvencija}

Prvi mednarodni pogodbi, ki sta bili namenjeni tudi zaščiti kulturnih dobrin med oboroženim spopadom, sta bili Druga in Četrta Haaška konvencija o zakonih in običajih vojne na kopnem ter pripadajoča pravilnika iz 1899 in 1907 (Keane, 2004, str. 4).

Sedemindvajseti člen pravilnika iz leta 1907 določa, da je med obleganji in bombardiranjem treba storiti vse, da se zaščitijo objekti, namenjeni veri, umetnosti, znanosti ali dobrodelnim dejavnostim, zgodovinski spomeniki, bolnišnice in kraji, kjer so zbrani bolni in ranjeni, če ti objekti niso uporabljeni v vojaške namene. Isti člen napadenemu nalaga dolžnost, da z očitnimi in jasno vidnimi znaki označi zaščitene zgradbe ter o tem obvesti nasprotnika (Haaški pravilnik o zakonih in običajih vojne na kopnem, člen 27, 1907). Pravilnik ne govori o tem, kako naj bi bil videti tak znak, je pa opisan v Haaški konvenciji o bombardiranju pomorskih sil med vojno iz $1907 .{ }^{3}$ Treba je omeniti tudi točko g 23. člena pravilnika, ki dovoljuje uničenje sovražnikove lastnine, torej tudi kulturne dobrine, v primeru vojaške nujnosti (Haaški pravilnik o zakonih in običajih vojne na kopnem, člen 23 g, 1907). Haaški pravilnik tako očitno prepoveduje samo bombardiranje zgoraj naštetih objektov in zgodovinskih spomenikov, vse druge oblike napada na takšne objekte pa dovoljuje. Pravilnik govori tudi o zaščiti kulturne dediščine med okupacijo. V njegovem 56. členu je zapisano, da je lastnina institucij, namenjenih veri, dobrodelnosti, izobraževanju, umetnosti in znanosti, zasebna lastnina, tudi ko gre za last države. Vsako plenjenje, uničenje ali namerno poškodovanje lastnine teh institucij, zgodovinskih spomenikov in umetniških del je prepovedano in bo predmet pravdnih postopkov (Haaški pravilnik o zakonih in običajih vojne na kopnem, člen 56, 1907).

Določila Haaškega pravilnika o zakonih in običajih vojne na kopnem so postala pravila običajnega prava in kot taka še veljajo. Pravilnik je vzpostavil tri načela glede zaščite kulturne dediščine. Kulturni spomeniki in objekti, namenjeni znanosti in umetnosti, ki morajo biti označeni z vidnimi znaki, so zaščiteni pred vojaškim

5. člen Haaške konvencije o bombardiranju pomorskih sil med vojno določa znak pravokotne oblike, ki je diagonalno razdeljen na dva trikotna dela; zgornji trikotnik je črne, spodnji pa bele barve. 
napadom, razen ko so uporabljeni za vojaški namen. Taka zaščita je podrejena vojaški nujnosti. Ob okupaciji mora biti kulturna dediščina obravnavana kot zasebna lastina; okupant je ne sme poškodovati, uničiti ali zapleniti (Senković, 2013, str. 7).

\subsection{Svetovni vojni}

Prva svetovna vojna je izpostavila neustreznost dotedanjega pravila o bombardiranju, ki je prepovedoval vsakršen napad ali bombardiranje nebranjenih krajev in vasi. Zaradi tehnološkega napredka različnih tipov orožja je bilo lahko praktično vsako mesto $\mathrm{v}$ zaledju fronte izpostavljeno zadetkom nasprotnikovega topništva ali letalstva. In zaradi visoke stopnje vojaške mobilizacije so bile vojaške enote nastanjene tudi v krajih v zaledju fronte in v nekem širšem smislu so bili ti kraji tudi branjeni. Posledično je bila vsa zasebna lastnina, razen kulturnih dobrin, ki jih je varoval 27. člen Haaškega pravilnika o zakonih in običajih vojne na kopnem, izpostavljena legalnemu napadu.

Prva svetovna vojna je torej pokazala, da so bila pravila o bombardiranju preohlapna. Komisija pravnikov, ki jo je leta 1922 imenovala Washingtonska konferenca o zmanjševanju oboroževanja, je pripravila osnutek pravil o zračnem bojevanju, ki je bil sprejet leto pozneje (Senković, 2013, str. 8). V osnutku je razlikovanje med branjenimi in nebranjenimi kraji nadomestilo razlikovanje med vojaškimi objekti in civilnim prebivalstvom. Prvi člen govori o tem, da je zračno bombardiranje legitimno le, ko je usmerjeno na vojaški cilj. Osnutek je zavezal vojaške poveljnike, da morajo storiti vse, kar je v njihovi moči, da se prizanese objektom, omenjenim v Haaškem pravilniku o zakonih in običajih vojne na kopnem (O`Keefe, 2006, str. 45). Osnutek ni bil nikoli formalno potrjen, saj ga je prehitela druga svetovna vojna, je pa predstavljal osnovo za nadaljnjo zaščito kulturnih dobrin. Napredek na tem področju je predstavljal tudi Roerichov pakt, ki predvideva nevtralnost zgodovinskih objektov. Ta je lahko kršena le takrat, ko se ti objekti uporabljajo za vojaške namene. Pakt uvaja tudi razpoznavni znak - rdeča krožnica na beli podlagi s tremi rdečimi krogi znotraj krožnice - za označevanje zaščitenih objektov. Roerichov pakt je podpisalo deset ameriških držav, ki so ga pozneje tudi ratificirale. Sporazum, ki se med državami pogodbenicami še vedno uporablja, je močno vplival na nastanek Haaške konvencije.

Druga svetovna vojna se je začela ob zelo neugodnem času za nadaljnji razvoj zaščite kulturnih dobrin. Vojaška nujnost, ki je še vedno imela prednost pred zaščito kulturnih dobrin, je vplivala na uničenje številnih mestnih središč in posameznih zgodovinskih spomenikov velike vrednosti za celotno človeštvo. Najbolj znan primer, morda celo simbol uničenja kulturnih dobrin med drugo svetovno vojno, je bombardiranje benediktinskega samostana Monte Cassino v Italiji. Nemška obrambna črta je potekala v bližini samostana, a nemške sile samostana niso zasedle. Zaradi napačnih obveščevalnih podatkov, da samostan uporablja nemška vojska, je zavezniški general Freyber ukazal bombardiranje samostana. Ruševine samostana so nato zasedle nemške enote in jih spremenile v utrdbo, ki je zavezniškim vojakom ni uspelo zavzeti vse do umika nemških enot. Da se uničevanje kulturnih dobrin ne 
bi ponovilo še na drugih območjih, so zavezniki pred invazijo v Normandiji zaostrili pravila bojevanja. General Eisenhower je poudaril, da gre v bitki za Evropo tudi za bitko za ohranitev civilizacije. »Na tej poti bodo naleteli na zgodovinske spomenike in kulturna središča, ki za svet simbolizirajo vse tisto, kar je treba ohraniti. Vsak poveljnik mora spoštovati in zavarovati te simbole ...«(Jogan, 2008, str. 46).

Kulturnim dobrinam pa ni grozila le nevarnost uničenja med vojaškimi spopadi. Nemške vojaške enote so z območij, kjer so izvajale okupacijo, prepeljale v Nemčijo številna umetniška dela. Mednarodno sodišče za vojne zločine v Nürnbergu je Alfreda Rosenberga, vodjo posebne enote Einsatzstab Rosenberg, katere naloga je bila obogatitev nemških umetniških zbirk, obsodila na smrt za vojne zločine in zločine proti človeštvu. Smrtna kazen je bila izvedena 16. oktobra 1946 (Keane, 2004, str. 12). Proces proti Rosenbergu in nekaterim drugim nacističnim veljakom, ki so bili obsojeni za plenjenje kulturnih dobrin, velja za prvo resno mednarodno uveljavljanje pravne zaščite kulturnih dobrin (Gottlieb, 2020, str. 293).

\subsection{Haaška konvencija}

Leta 1949 je Organizacija Združenih narodov za izobraževanje, znanost in kulturo ${ }^{4}$ začela priprave na nov dogovor o zaščiti kulturnih dobrin med oboroženimi spopadi. Leto pozneje je generalni direktor sklical delovno skupino, ki je pripravila osnutek pogodbe. Med 21. aprilom in 14. majem 1954 je v nizozemskem Haagu potekala medvladna konferenca, na kateri so sodelovale delegacije iz 56 držav. 14. maja 1954 sta bila sprejeta Konvencija o varstvu kulturnih dobrin v primeru oboroženega spopada $^{5}$ in Pravilnik za izvrševanje Konvencije, ki je integralni del Haaške konvencije, ter Protokol k Haaški konvenciji, danes poznan kot Prvi protokol. Oba dokumenta sta začela veljati 7. avgusta 1956 (O`Keefe, 2006, str. 93-94). ${ }^{6} \mathrm{~V}$ preambuli Haaške konvencije je zapisano: »/. . ./ kulturnim dobrinam prizadeta škoda ne glede na to, kateremu narodu pripadajo, pomeni oškodovanje kulturne dediščine vsega človeštva, saj prispeva vsak narod k svetovni kulturi svoj delež. « (Konvencija o varstvu kulturnih dobrin v primeru oboroženega spopada, 1954, str. 1). Haaška konvencija je prvi mednarodni sporazum, ki govori izključno o zaščiti kulturnih dobrin med oboroženim spopadom. Najpomembnejši člen Haaške konvencije je njen 4. člen. Z njim so se države pogodbenice zavezale, da bodo v času oboroženega spopada spoštovale kulturne dobrine, ki so na njihovem ozemlju in tiste na ozemlju drugih držav pogodbenic (Konvencija o varstvu kulturnih dobrin v primeru oboroženega spopada, 1954, str. 2). 16. člen Haaške konvencije opredeljuje znak konvencije. Ta ima obliko ščita, ki je spodaj priostren, razdeljen na štiri navzkrižna polja, obarvan modro in belo; ( ̌̌čit je sestavljen iz modrega kvadrata, katerega eden od oglov predstavlja spodnji del ščita, in iz modrega trikotnika nad kvadratom, tako

\footnotetext{
4 Vnadaljevanju Unesco.

Vnadaljevanju Haaška konvencija.

${ }^{6}$ Držav pogodbenic Haaške konvencije je trenutno 133, držav pogodbenic Prvega protokola je 110.
} 
da oba skupaj z obeh strani omejujeta po en bel trikotnik (Konvencija o varstvu kulturnih dobrin v primeru oboroženega spopada, 1954, str. 6 ). ${ }^{7}$

Haaška konvencija ni izpolnila pričakovanj, ki so se pojavila ob njenem nastanku. Razlogov za toje več. Zaščita, ki joje zagotavljala kulturnim dobrinam, je predstavljala le majhen napredek glede na do njenega nastanka veljavne omejitve bojevanja. Režim posebnega varstva, ki ga je predvidela, se je izkazal za neuporabnega, prav tako sistem mednarodnega nadzora, ki je bil preambiciozen in zato neuresničljiv. S sprejetjem dodatnih protokolov k Ženevskim konvencijam iz leta 1977 pa je Haaška konvencija postala zastarela (Senković, 2013, str. 11-12).

\subsection{Drugi protokol}

Haaška konvencija je ponovno postala aktualna v 80. in 90. letih 20. stoletja. V iranskoiraški vojni je prišlo do uničenja kulturnih dobrin na obeh, v vojno vpletenih straneh. Prav tako se je zgodilo med vojaškimi spopadi na ozemlju nekdanje Jugoslavije. Leta 1991 je nizozemska vlada naročila recenzijo Haaške konvencije. Poročilo je pokazalo, da je Haaška konvencija še vedno veljavna in delujoča pogodba, katere težava je neupoštevanje izvedbe. Revizija konvencije je svoj vrhunec dosegla na konferenci v Haagu leta 1999, na kateri so delegati 26. marca sprejeli Drugi protokol k Haaški konvenciji o varstvu kulturnih dobrin v primeru oboroženega spopada (Senković, 2013, str. 12).

Drugi protokol Haaško konvencijo dopolnjuje in jo v nobenem primeru ne nadomešča. Pomembnejše spremembe, ki jih prinaša Drugi protokol, so členitev odgovornosti za varstvo kulturnih dobrin, seznam ukrepov, ki naj jih članice sprejmejo v miru, in vzpostavitev sklada za pomoč pri izvedbi teh ukrepov, definicija vojaške nujnosti, zahteva po sorazmernosti napadov, prepoved arheoloških izkopavanj na okupiranih območjih, vzpostavitev razširjenega varstva ter definicija kazenskih sankcij zaradi kršitve konvencije. V 15. členu je opredeljenih pet kršitev, za katere se uvaja individualna kazenska odgovornost (Drugi protokol k Haaški konvenciji o varstvu kulturnih dobrin v primeru oboroženega spopada, člen 15, 1999).

\subsection{Dopolnilna protokola I in II k Ženevskim konvencijam iz leta 1949}

Dopolnilna protokola I in II k Ženevskim konvencijam iz leta 1949 sta bila sprejeta leta 1977. Prvi Dopolnilni protokol pokriva področje mednarodnih oboroženih spopadov, drugi pa področje notranjih oboroženih spopadov. Oba vsebujeta tudi člene, ki se nanašajo na kulturne dobrine.

Tako kot Haaška konvencija tudi Dopolnilna protokola I in II k Ženevskim konvencijam iz leta 1949 govorita o zaščiti kulturnih dobrin, le da sta v opredelitvah zaščite nekoliko »ožja«. 53. člen Dopolnilnega protokola I prepoveduje storiti

\footnotetext{
Nekateri dogodki potrjujejo, da označitev kulturne dobrine pripomore k njenemu uničenju. Nedolgo zatem, ko so med obleganjem Vukovarja leta 1991 na Vukovarski muzej namestili znak konvencije, je ta postal cilj obstreljevanja pripadnikov JLA.
} 
kakršno koli sovražno dejanje proti zgodovinskim spomenikom, umetniškim delom ali svetiščem, ki so kulturna in duhovna dediščina naroda. 16. člen Dopolnilnega protokola II pa dodatno prepoveduje uporabo omenjenih kulturnih dobrin za podporo vojaškemu delovanju (Zidar, 2019, str. 342). V teh primerih gre za zaščito kulturnih dobrin naroda, medtem ko Haaška konvencija govori o celotnem človeštvu. Kljub razlikam v definicijah lahko iz komentarja Mednarodnega ICRC k Dopolnilnim protokolom I in II razberemo, da je osnovna ideja vseh dokumentov enaka (Rawan, 2017, str. 105; O‘Keefe, 2006, str. 209).

\section{SPOŠTOVANJE KULTURNIH DOBRIN}

Skrb za kulturne dobrine zadnja leta ni več v izključni domeni kulturnega sektorja, temveč se je preselila oziroma se seli tudi na obrambni sektor. Kulturne dobrine so vse bolj vpete v oborožene spopade zaradi njihovega izjemnega pomena, ki ga imajo v posameznih družbah, ter zaradi političnega vpliva, ki ga ima njihovo uničenje. V preambuli Severnoatlantske pogodbe piše, da so pogodbenice odločene varovati svobodo, skupno dediščino in civilizacijo svojih narodov, ... (Severnoatlantska pogodba, preambula, 1949). Varovanje kulturnih dobrin kot del varovanja skupne dediščine tako predstavlja tudi vrednoto organizacije Nato.

Varovanje kulturnih dobrin med oboroženimi spopadi ima za vojaške sile strateški in pravni pomen ter verjetno nima takojšnjega neposrednega učinka na vojaško operacijo, nasprotno pa lahko uničenje ali poškodovanje, kraje in drugo neustrezno ravnanje s kulturnimi dobrinami ogrozi uspeh operacije ter lahko negativno odmeva v lokalni in svetovni javnosti. Lokalno prebivalstvo se lahko zaradi nespoštovanja kulturnih dobrin obrne proti pripadnikom oboroženih sil, ki delujejo na določenem območju. Ropanje Iraškega nacionalnega muzeja leta 2003 je na primer preraslo v simbol popolne nemoči okupacijskih sil preprečiti vsesplošni kaos. Ko imajo oborožene sile možnost preprečiti ropanje kulturnih dobrin, pa tega ne storijo, ima to lahko dolgotrajen vpliv na ugled vojaške operacije. Nezakonito trgovanje s kulturnimi dobrinami predstavlja finančni prihodek za različne oborožene skupine in teroristične organizacije, torej bi varovanje kulturnih dobrin odrezalo te skupine od znatnega dela njihovih virov financiranja. Skrb za kulturne dobrine pozitivno vpliva na odnose z javnostjo, saj tako lahko na svojo stran pridobijo prebivalce določene regije ali države (Foilant, 2015, str. 15), pridobita se njihova »razum in srce ${ }^{8}{ }^{8}$ Razumevanje pomena kulturnih dobrin, povezano $\mathrm{z}$ njihovo spoštljivo obravnavo, lahko deluje kot multiplikator bojne moči (Senković, 2013, str. 52). To se je posebej pokazalo v operaciji Unified Protector. Obveščevalni strokovnjaki so ob pomoči libijskih arheologov in zgodovinarjev ter različnih vladnih, nevladnih in mednarodnih organizacij sestavili nabor libijskih kulturnih dobrin, ki so zahtevale posebno pozornost. Ta nabor so nato vključili v t. i. »no-strike list«, ki so ga Natove sile upoštevale pri izvajanju vojaških akcij (O`Keefe in drugi, 2016, str. 30). Pozitivna publiciteta, ki jo je Nato prejel na podlagi preprečevanja uničenja kulturnih dobrin

8 Angl. hearts and minds. 
v Libiji, je še danes v strokovnih krogih uporabljena za zgled delovanja na tem področju.

V pravnem smislu je neuspeh neke vojaške sile, da bi upoštevala vse ukrepe za zaščito kulturnih dobrin, ki jih predvideva mednarodno pravo, neuspeh države, iz katere prihaja ta vojaška sila. Taki državi bi bilo lahko naloženo plačilo odškodnine za uničenje kulturnih dobrin (O'Keefe in drugi, 2016, str. 2). ${ }^{9}$ Vsaka posameznica in posameznik, ki nosita uniformo, sta odgovorna za uničenje ali poškodovanje kulturnih dobrin med oboroženim spopadom in se lahko zaradi tega znajdeta pred sodiščem z obtožbo za vojne zločine ter celo za zločine proti človeštvu. ${ }^{10}$ Pri tem je treba omeniti, da se med odgovorne ne štejejo le posamezniki, ki so kulturno dobrino ali dobrine v resnici uničili ali poškodovali, temveč tudi poveljniški kader, ki ne prepreči takih zločinov.

Treba je tudi omeniti, da povečan interes mednarodne skupnosti glede varovanja kulturnih dobrin med oboroženimi spopadi pomeni svojevrsten paradoks. Bolj kot strokovna in splošna javnost govorita o pomenu kulturnih dobrin in njihovega varovanja, bolj te kulturne dobrine postajajo taktično in strateško zanimiv cilj oboroženih skupin in terorističnih organizacij. Nekatere raziskave nakazujejo, da se je pozornost Islamske države Iraka in Levanta usmerila na antično Palmiro in njeno uničenje šele po tem, ko sta mednarodna skupnost in zlasti Unesco izrazila skrb za njeno usodo (Rosén, 2017a, str. 17).

\section{IMPLEMENTACIJA HAAŠKE KONVENCIJE}

Haaška konvencija zavezuje države pogodbenice k zaščiti lastnih kulturnih dobrin. O tem govori 3. člen Haaške konvencije: »Visoke pogodbenice se zavezujejo, da bodo že v mirnem času pripravile zavarovanje kulturnih dobrin, ki so na njihovem ozemlju, pred verjetnimi posledicami oboroženega spopada, tako da bodo sprejele vse ukrepe, ki jih imajo za nujno potrebne« (Konvencija o varstvu kulturnih dobrin v primeru oboroženega spopada, 1954, str. 2).

Najpomembnejši ukrepi, ki jih mora država pogodbenica Haaške konvencije izvajati zlasti v obdobju miru, so:

- priprava zaščite: sestava inventarjev, načrtovanje varnostnih ukrepov proti požaru in porušitvi, priprava premične dediščine za evakuacijo oziroma zagotovitev možnosti zavarovanja in situ ter opredelitev odgovornosti, ki je uporabna tudi ob drugih oblikah ogroženosti dediščine;

\footnotetext{
Združeni narodi so naložili Iraku plačilo odškodnine v znesku 19 milijonov ameriških dolarjev nekemu kuvajtskemu zbiratelju kot nadomestilo za uničenje in krajo delov zbirke, ki so ju povzročili pripadniki iraške vojske med invazijo na Kuvajt.

${ }^{10}$ Mednarodno kazensko sodišče je leta 2016 obsodilo Ahmada al Faqija Al Mahdija na devet let zapora zaradi napada na verske in zgodovinske objekte v Timbuktuju. Tako je postal prva oseba, obsojena le zaradi zločina nad kulturnimi dobrinami.
} 
- določitev omejenega števila kulturnih dobrin, ki jih je mogoče postaviti pod posebno zaščito oziroma $\mathrm{v}$ mednarodni register kulturne dediščine;

- načrtovanje posebej izurjenega osebja oziroma posebnih služb, ki bodo znotraj oboroženih sil zagotavljale spoštovanje do kulturne dediščine in sodelovanje s civilnimi oblastmi;

- popularizacija besedil Haaške konvencije in njenega Drugega protokola;

- odstranitev premičnih kulturnih dobrin iz bližine vojaških objektov in morebitnih ciljev ter preprečitev postavljanja vojaških objektov $\mathrm{v}$ bližini kulturnih dobrin (Kladnik, 2010, str. 178).

Finska predstavlja dober zgled glede implementacije Haaške konvencije. V sklopu mirnodobnih priprav so na ravni države začeli pripravljati seznam kulturnih dobrin, tako premičnih kot nepremičnih. Ta seznam bo uporabljen za zaščito izbranih kulturnih dobrin pred naravnimi in drugimi nesrečami ter ob vojaški grožnji. Seznam temelji na merilih, ki so v Haaški konvenciji, ki pa so zelo relativni. Tako so se finski strokovnjaki znašli pred znano dilemo, kje je meja, ki loči pomembnejše in manj pomembne kulturne dobrine. Odločili so se, da bodo odločali o vsaki kulturni dobrini posebej. Naslednji korak v projektu pa predstavlja ocena ogroženosti vsake kulturne dobrine, ki je svoje mesto dobila na seznamu (Pesu, 2012, str. 91-95).

Ravnanje Hrvaške leta 1991 je prav tako primer zglednega ukrepanja ob grožnji oboroženega spopada. Pred začetkom oboroženih spopadov so ustrezne ustanove izvedle izobraževanja za muzejske delavce o ravnanju s kulturnimi dobrinami $\mathrm{v}$ izrednih razmerah. Ti so na mikrofilmih sistematično zabeležili stanje muzejskih zbirk, mikrofilmi pa so bili shranjeni na treh različnih lokacijah. Stalne zbirke so preselili iz muzejev in galerij na varnejša mesta. Stavbe so bile izbrane vnaprej, pregledali pa so jih tudi ustrezni strokovnjaki. Tako so zavarovali več kot 6000 zabojev umetnin. Nepremični spomeniki so bili zavarovani z različnimi tehničnimi ukrepi. Iz cerkev so evakuirali dragocene predmete; težje predmete, kot so oltarji in orgle, pa so bili zavarovani in situ. Po topniškem napadu na zgodovinsko utrdbo v Erdutu leta 1991 so hrvaške oblasti na jugoslovanski Zvezni sekretariat za obrambo poslale sezname zavarovanih kulturnih dobrin (Senković, 2013, str. 19-20).

\section{STANJE V SLOVENIJI}

Republika Slovenija še nima pripravljenega inventarja najpomembnejših kulturnih dobrin, kot ga predvideva Haaška konvencija (Kladnik, 2013, str. 189). Deloma bi ga lahko nadomestil Register kulturne dediščine, ki je osrednja zbirka podatkov o dediščini v Sloveniji. Register nepremične kulturne dediščine Ministrstvo za kulturo razvija od leta 1991. Leta 2009 se mu je pridružil Register nesnovne kulturne dediščine, register premične kulturne dediščine pa še ni vzpostavljen (Register kulturne dediščine).

Sistematično urejanje področja varovanja kulturnih dobrin med oboroženimi spopadi se je začelo v prvem desetletju 21. stoletja. V okviru Ciljnih raziskovalnih programov 
Znanje za varnost in mir 2006-2010 sta potekala dva projekta, ki ju je financiralo Ministrstvo za obrambo Republike Slovenije, strokovni nadzor nad projektoma pa je opravljal Vojaški muzej SV.

Projekt M4-0207, poimenovan Izdelava in demonstracija modela za načrtovanje ohranjanja umetnostnozgodovinske dediščine v vojnih spopadih, je bil zasnovan kot raziskava, ki bo prispevala $\mathrm{k}$ ohranjanju slovenske umetnostnozgodovinske dediščine. $\mathrm{Z}$ raziskavo je bil oblikovan model za načrtovanje ohranjanja umetnostnozgodovinskih spomenikov v primeru vojne, terorizma in naravnih nesreč. Zasnovan je bil kot interdisciplinarna raziskava, v kateri so sodelovali strokovnjaki umetnostnozgodovinske in gradbene stroke (Murovec, 2009, str. 4). Projekt je zajel 70 vrhunskih spomenikov slovenske sakralne umetnosti, ki so bili izbrani po različnih umetnostnozgodovinskih in zunanjih merilih, kot so kakovost, slog, regionalna pokritost, stanje ohranjenosti spomenika, nacionalni pomen, strateška lega objekta itn. V sklopu projekta so bili zbrani vsi pravni akti s področja varovanja kulturne dediščine, pripravljen je bil arhiv spomenikov z izčrpno fotografsko dokumentacijo, arhitektonskimi posnetki in analizami materialov ter tehnik in s predlogi fizičnih ter drugih zaščitnih ukrepov. Pripravljena je bila natančna dokumentacija o vseh 70 izbranih spomenikih ter narejen zemljevid umetnostnih spomenikov državnega pomena. Hkrati je bila narejena tudi metodologija za oceno ogroženosti spomenikov (Murovec, 2009, str. 4, 8).

Projekt M4-0228, poimenovan Varovanje kulturne dediščine v izrednih razmerah, je bil pripravljen zaradi analize takratnega dokumentiranja in praktične ter pravne zaščite predmetov in objektov kulturne dediščine v izrednih razmerah. Temeljni cilj projekta je bila priprava smernic za dokumentiranje in spremljanje stanja spomenikov premične in nepremične kulturne dediščine. V okviru projekta je bila izdana tudi znanstvena monografija Pravno varstvo dediščine avtorja Savina Jogana (Guštin, 2009, str. 4, 7).

S tema projektoma je Republika Slovenija začela izpolnjevati svoje obveznosti kot podpisnica Haaške konvencije in pripravila ustrezen sistem varovanja kulturne dediščine državnega pomena ob oboroženem spopadu. A dobro delo bi bilo treba nadaljevati in projekt razširiti tudi na preostale vrhunske primerke nepremične kulturne dediščine, arheološke ostaline in objekte, ki hranijo premično kulturno dediščino.

\section{UKREPI VOJAŠKE NARAVE}

Sedmi člen Haaške konvencije govori o ukrepih vojaške narave. V njegovi prvi alineji je zapisano: »Visoke pogodbenice se zavezujejo, da bodo že v mirnem času vključile v svoje vojaške pravilnike ali vojaška navodila primerne odločbe, skaterimi se zagotavlja izpolnjevanje te konvencije, in da bodo osebje svojih oboroženih sil vzgojile že v mirnem času, da spoštujejo kulturo in kulturne dobrine vseh narodov«. V drugi alineji pa je zapisano: »Zavezujejo se, da bodo že v mirnem času pripravile 
ali ustanovile v okviru svojih oboroženih sil službe ali strokovno osebje z nalogo, da bodo skrbele za spoštovanje kulturnih dobrin in sodelovale s civilnimi oblastmi, pristojnimi za zavarovanje teh dobrin« (Konvencija o varstvu kulturnih dobrin $\mathrm{v}$ primeru oboroženega spopada, 1954, str. 3).

Različne države so uporabile različne pristope pri implementaciji 7. člena Haaške konvencije. Nekatere države so ustanovile posebne vojaško-policijske oddelke. Italija je že leta 1969 ustanovila posebno enoto karabinjerjev za zaščito kulturnih dobrin, ki je med drugim sodelovala na nekaterih mirovnih misijah. V avstrijskih oboroženih silah so zaposleni (rezervni) častniki, ki so odgovorni izključno za varovanje kulturnih dobrin, $\mathrm{v}$ švicarskih oboroženih silah pa to nalogo opravljajo častniki, ki imajo posebno znanje o ohranjanju kulturnih dobrin (Senković, 2013, str. 36-37). V Slovenski vojski oziroma na Ministrstvu za obrambo trenutno ni strokovnjakov, ki bi se ukvarjali le z varovanjem kulturnih dobrin med oboroženim spopadom. Še najbolj se z njo ukvarjajo pripadniki Vojaškega muzeja Slovenske vojske. Muzej je matična muzejska ustanova Slovenske vojske, ki organizira in opravlja muzejsko dejavnost s tematiko vojaške in vojne preteklosti Slovencev ter slovenskega etničnega prostora in obrambnih sil. Temeljne dejavnosti Vojaškega muzeja Slovenske vojske so sistematično zbiranje, raziskovanje, proučevanje in strokovno obravnavanje muzejskega gradiva; izvajanje konservatorskih in restavratorskih del ter pripravljanje muzejskega gradiva za trajno shranjevanje in javno razstavljanje, objavljanje rezultatov preučevanega gradiva in njegovo uporabljanje za kulturne, znanstvene in izobraževalne namene; raziskovanje vojaških arheoloških značilnosti; ocenjevanje muzejskega vojaškozgodovinskega gradiva; opravljanje znanstvenoraziskovalnega dela ter objavljanje strokovnih in znanstvenih del ter izdajanje priložnostnih publikacij; sistematično zbiranje in hranjenje strokovne literature s področja delovanja; organiziranje muzejskih razstav in drugih oblik muzejske dejavnosti, ki imajo širši družbeni ter kulturni pomen; vodenje muzeološke evidence in dokumentacije o muzejskem gradivu ter muzejski dejavnosti v skladu s pravilnikom o vodenju inventarne knjige; posredovanje muzejskega gradiva in svojih publikacij drugim muzejem ter podobnim ustanovam v državi in tujini; spremljanje in izmenjevanje izkušenj o sodobni muzeologiji v državi in svetu; organiziranje muzejskih razstav v okviru spomeniških kompleksov velikih spopadov in bitk, zlasti v obdobju osamosvojitvene vojne leta 1991; organiziranje dejavnosti glede odpiranja muzejev rodov in služb Slovenske vojske ter spominskih sob; ukvarjanje s pedagoško-promocijskim in vzgojnoizobraževalnim delom; načrtovanje finančnih sredstev za svojo dejavnost; upravljanje materialnih in denarnih sredstev ter opravljanje materialnega in finančnega poslovanja skladno s predpisi o sredstvih in financiranju Slovenske vojske ter z določbami Pravilnika o muzejski dejavnosti v Slovenski vojski; opravljanje drugih zadev glede muzejske dejavnosti (Pravilnik o muzejski dejavnosti v Slovenski vojski, člen 9, 2005). Pripadnik Vojaškega muzeja SV je tudi civilni funkcionalni strokovnjak za področje varovanja kulturnih dobrin. Leta 2019 se je udeležil dveh mednarodnih vaj v organizaciji Večnacionalne skupine 
za CIMIC v Motti di Livenza: Double River $2019^{11}$ in Trident Jupiter 2019, kjer je bil odgovoren za področje varovanja kulturnih dobrin.

\subsection{Izobraževanje in usposabljanje oboroženih sill}

S prenašanjem skrbi za kulturne dobrine tudi na obrambni sektor so se vojaški poveljniki in drugi pripadniki oboroženih sil znašli pred nekaterimi zagatami. Zavedanje o pomenu kulturnih dobrin ni nekaj, kar bi imel vsak posameznik že ponotranjeno $\mathrm{v}$ sebi. Poleg tega imajo pripadniki različnih oboroženih sil različno znanje o varovanju kulturnih dobrin med vojaškim izobraževanjem in usposabljanjem. Raziskava, ki je bila izvedena v okviru Natovega programa Znanost za varnost in mir, žal nakazuje, da je varovanje kulturnih dobrin nekoliko zapostavljeno med usposabljanjem vojaških enot posameznih članic Nata (Rosén, 2017b, str. 21). Le dobro usposobljen pripadnik oboroženih sil bo znal ustrezno ravnati ob stiku s kulturnimi dobrinami in ne bo s svojim delovanjem pripomogel $\mathrm{k}$ njenemu poškodovanju ali uničenju. Za dobro načrtovanje in izvedbo vojaških operacij pa je danes treba tudi dobro poznati vse pravne norme in pravila glede varovanja kulturnih dobrin.

Primere dobre prakse na področju usposabljanja pripadnikov oboroženih sil za varovanje kulturnih dobrin najdemo v Združenih državah Amerike. Na podlagi izkušenj, ki so jih pripadniki oboroženih sil Združenih držav Amerike pridobili med vojaškimi operacijami, je posebna skupina strokovnjakov v vojaškem oporišču Fort Drum pripravila serijo modelov in pilotskih projektov za podporo usposabljanju pripadnikov 10. gorske divizije in Nacionalne garde. Ti modeli in projekti so med drugim zajemali pripravo replike arheološkega najdišča, na kakršno lahko pripadniki oboroženih sil naletijo na Bližnjem vzhodu, ki so ga izdelali arheologi, in je sredstvo za usposabljanje. Poleg arheološkega najdišča so bile izdelane tudi replike tradicionalnih pokopališč, saj so pripadniki oboroženih sil Združenih držav Amerike večkrat poročali, da nasprotna stran uporablja nagrobne kamne kot kritje med vojaškimi spopadi. Na vadišču Vojnega letalstva Združenih držav Amerike so bile zgrajene tudi replike starodavnih ruševin, da se lahko letalske posadke urijo v pristopu, ki bi kar najbolj zmanjšal možnost kolateralne škode med letalskimi napadi (Rush, 2017, str. 80-81, 83). Tako pripadniki oboroženih sil Združenih držav Amerike dobijo praktične izkušnje iz obnašanja na zgodovinskih območjih in ohranjanja arheoloških najdišč, še preden se odpravijo na vojaške operacije.

Pomembno vlogo pri širjenju zavedanja o pomenu varovanja kulturnih dobrin med pripadniki oboroženih sil Združenih držav Amerike ima tudi neformalno izobraževanje. Strokovnjaki iz oporišča Fort Drum so v sodelovanju z državno univerzo iz Colorada pripravili posebne igralne karte. Vsaka izmed 52 kart v paketu ima različno izobraževalno sporočilo, povezano s pomenom varovanja kulturnih dobrin. Na nekaterih kartah so fotografije pomembnih kulturnih dobrin, na drugih pa

\footnotetext{
II Več o vaji v članku z naslovom Slovenski civilni funkcionarji na vaji Double River 2019, ki je izšel v Reviji Slovenska vojska aprila 2019.
} 
navodila vojakom, kako ravnati v bližini teh dobrin. Prvi paket kart se je osredotočil na Irak in od leta 2007 je bilo razdeljenih že 150.000 paketov kart. Naslednja dva paketa kart sta osredotočena na Egipt in Afganistan (Rush, 2017, str. 87-88).

\subsection{Uporaba kulturnih dobrin in napad nanje}

S Haaško konvencijo so se visoke pogodbenice zavezale, da kulturnih dobrin in njihove najbližje okolice ne bodo uporabljale za namene, ki bi ob oboroženem spopadu lahko povzročili njihovo uničenje ali poškodovanje; da se bodo odpovedale vsakršnim sovražnim dejanjem proti takim dobrinam; da bodo prepovedale, preprečevale in, če bo treba, ustavile vsakršno obliko kraje, ropanja ali odtujevanja kulturnih dobrin, vsako vandalsko dejanje proti omenjenim dobrinam ter da ne bodo zasegale premičnih kulturnih dobrin, ki so na ozemlju druge visoke pogodbenice, in da se bodo vzdržale vseh nasilnih dejanj, namenjenih proti kulturnim dobrinam (Konvencija o varstvu kulturnih dobrin v primeru oboroženega spopada, 1954, str. 1-13). Omenjene zahteve je mogoče opustiti samo v primerih, ko to zahteva vojaška nujnost. Haaška konvencija ne pojasnjuje, kateri so ti primeri.

Kulturne dobrine se uporabljajo za vojaške namene, če se jih izkorišča za premeščanje vojaškega osebja ali materiala; če potekajo v njej dejavnosti, ki so neposredno povezane z vojnimi operacijami, če je v njej vojaško osebje ali če se v njej izdeluje vojaški material. V takih primerih lahko kulturna dobrina postane vojaški objekt (Senković, 2013, str. 22).

Veliko težavo pri obravnavani temi je pomenila nedefiniranost vojaške nujnosti v Haaški konvenciji. Šesti člen Drugega protokola k Haaški konvenciji dopolnjuje 4. člen Haaške konvencije in postavlja dva pogoja, da bi lahko uporabili izjemo vojaške nujnosti. Kulturna dobrina mora biti po svoji funkciji spremenjena v vojaški cilj, obenem pa ne smejo obstajati druge izvedljive možnosti za pridobitev podobne vojaške prednosti, kot jo daje usmeritev sovražnega dejanja zoper ta cilj (Drugi protokol k Haaški konvenciji o varstvu kulturnih dobrin v primeru oboroženega spopada, 1999). V Dopolnilnem protokolu I k Ženevskim konvencijam z dne 12. avgusta 1949 o zaščiti žrtev mednarodnih oboroženih spopadov je vojaški cilj opisan kot objekt, ki zaradi svoje narave, lokacije, namena ali uporabe pomeni efektiven prispevek k vojaški akciji in katerega delno ali popolno uničenje, zavzetje ali nevtralizacija pomeni resnično vojaško prednost (Zidar, 2019, str. 90). Šesti člen Drugega protokola ob definiciji vojaške nujnosti uvaja pomembne omejitve. Tisti, ki uporablja kulturne dobrine v namene, ki jih bodo verjetno izpostavili uničenju ali poškodovanju, se lahko sklicuje na opustitev varstva na podlagi neizogibne vojaške nujnosti samo, kadar in dokler ni na voljo nobene izbire med tako uporabo kulturnih dobrin in drugo mogočo metodo za pridobitev podobne vojaške prednosti; odločitev o sklicevanju na neizogibno vojaško nujnost lahko sprejme le častnik, ki poveljuje enoti, enaki bataljonu ali manjši enoti, če okoliščine ne dovoljujejo drugače; ob napadu je treba zagotoviti učinkovito vnaprejšnje opozorilo, kadar to dopuščajo okoliščine (Drugi protokol k Haaški konvenciji o varstvu kulturnih dobrin v primeru oboroženega spopada, člen 6, 1999). 
Leta 2003 so koalicijske sile iz zraka posnele slike, ki so dokazovale, da so iraške sile parkirale vojaška vozila med muzejski kompleks, ki je bil označen s spoznavnim znakom Haaške konvencije, in Ktezifonski obok, največji opečnati obok na svetu (Senković, 2013, str. 22). To dejanje je predstavljalo očitno kršitev Haaške konvencije. Sedmi člen Drugega protokola obravnava naključno škodo, ki doleti kulturne dobrine v spopadu. Od sil v spopadu zahteva, da pred napadom preverijo, ali cilji, ki naj bi bili napadeni, niso morda zavarovane kulturne dobrine. Sile v spopadu se morajo odpovedati napadu, za katerega je mogoče pričakovati, da bo povzročil naključno škodo na kulturnih dobrinah. Prav tako se morajo odpovedati napadu oziroma ga začasno ustaviti, če je očitno, da je cilj zavarovana kulturna dobrina in je mogoče pričakovati, da bo napad povzročil nesorazmerno naključno škodo na kulturni dobrini glede na pričakovano konkretno in neposredno vojaško prednost (Drugi protokol k Haaški konvenciji o varstvu kulturnih dobrin v primeru oboroženega spopada, člen 7, 1999). Od vojaškega poveljnika se zahteva, da opravi test sorazmernosti med morebitno vojaško prednostjo in morebitno škodo na kulturnih dobrinah. Vojaški poveljniki se lahko srečujejo s težkimi odločitvami glede varovanja kulturnih dobrin. Večkrat je težko oceniti vrednost kulturne dobrine in zato je tako pomembno usposabljanje pripadnikov oboroženih sil pred odhodom $\mathrm{v}$ vojaško operacijo ali na misijo. Med zalivsko vojno leta 1991 so iraške vojaške sile skrile dve vojaški letali med ruševine starodavnega sumerskega templja v Uru. Test sorazmernosti je prepričal koalicijsko vojaško poveljstvo, da se ni odločilo za napad. Med odločanjem so primerjali zgodovinsko vrednost templja z nevarnostjo, ki sta jo predstavljali vojaški letali. Ker v bližini ni bilo vzletne steze, sta bili letali praktično neuporabni za boj (O`Keefe in drugi, 2016, str. 35).

V Slovenski vojski je na načelni ravni poskrbljeno za varovanje kulturnih dobrin. V 321. členu Pravil službe v Slovenski vojski je med drugim zapisano, da pripadniki in enote Slovenske vojske spoštujejo kulturne, zgodovinske in naravne spomenike, verske in druge objekte, varovane po mednarodnem pravu; spoštujejo nedotakljivost objektov, ki so označeni z razpoznavnimi znaki, določenimi po mednarodnem pravu, ter jih ne napadajo; poročajo nadrejenemu o sumu kršitve mednarodnega vojnega ter humanitarnega prava (Pravila službe v Slovenski vojski, člen 321, 2009). 322. člen Pravil službe v Slovenski vojski pa prepoveduje napadati označena zaščitena območja ali objekte, kot so bolnišnice, demilitarizirana ali varna območja, nebranjene kraje ter kulturne, zgodovinske in naravne spomenike ter verske in druge objekte, zaščitene po mednarodnem pravu (Pravila službe v Slovenski vojski, člen 322, 2009). V Vojaški doktrini je zapisano, da kulturne dobrine in kulturni spomeniki ne smejo biti cilj ali se uporabljati v vojaške namene (Furlan in sod., 2006, str. 47).

Kulturna dediščina je lastnina celotnega človeštva, zato je njeno ohranjanje dolžnost celotne mednarodne skupnosti. Prve misli o njeni zaščiti so se začele pojavljati že zgodaj v človeški zgodovini, bolj poglobljeno pa so se posamezniki s tematiko začeli ukvarjati v 16. in 17. stoletju. Svoj vrh je mednarodnopravna zaščita dosegla s Konvencijo o varstvu kulturnih dobrin v primeru oboroženega spopada in njenima Prvim in Drugim protokolom. 
Sklep Kulturne dobrine imajo vedno večjo vlogo tudi pri sodobnih oboroženih spopadih. Pri tem igrajo svojo vlogo tudi oborožene sile. Pripadniki oboroženih sil morajo biti dobro usposobljeni za spoštovanje kulture in kulturnih dobrin drugih narodov ter $\mathrm{s}$ področja varovanja kulturnih dobrin, saj bodo le tako lahko primerno odreagirali ob stiku z njimi in ne bodo povzročali nenamerne škode. Prav usposabljanju s področja varovanja kulturnih dobrin bi lahko oborožene sile namenjale več pozornosti.

Varovanje kulturnih dobrin je pomembno z več vidikov. Poleg ohranjanja dediščine naših prednikov lahko skrb za kulturne dobrine pripomore k boljšemu sprejetju pripadnikov oboroženih sil od lokalnega prebivalstva, medtem ko nespoštovanje kulturnih dobrin lahko povzroči obraten proces. Skrb za kulturno dediščino je pomembna tudi za legitimacijo misije ali operacije v lokalnem področju. Preprečitev ropanja kulturnih dobrin in posledično preprečitev ilegalne trgovine kulturnih dobrin pomaga pri zmanjšanju finančnih sredstev različnih oboroženih skupin in terorističnih organizacij, kar lahko zmanjša njihovo učinkovitost in skrajša trajanje konflikta. Varovanje kulturnih dobrin pa je pomembno tudi s stališča postkonfliktne obnove. Kulturni turizem je v svetovnem merilu v porastu in tako pridobljena finančna sredstva pripomorejo k obnovi v oboroženem spopadu uničenega območja, dežele ali države.

$\mathrm{Na}$ Ministrstvu za obrambo in v Slovenski vojski je matična muzejska ustanova, ki se ukvarja z ohranjanjem kulturne dediščine, Vojaški muzej Slovenske vojske. Implementacija Haaške konvencije in njenih dveh protokolov se je na ravni obrambnega sistema v Republiki Sloveniji začela z dvema projektoma, ki ju je financiralo Ministrstvo za obrambo. V okviru projekta $\mathrm{z}$ naslovom Izdelava in demonstracija modela za načrtovanje ohranjanja umetnostnozgodovinske dediščine v vojnih spopadih je bil pripravljen seznam 70 najpomembnejših spomenikov slovenske sakralne umetnosti z izčrpno fotografsko dokumentacijo, arhitektonskimi posnetki in analizami materialov in tehnik ter s predlogi fizičnih in drugih zaščitnih ukrepov. V projektu z naslovom Varovanje kulturne dediščine v izrednih razmerah pa so bili oblikovani vzorčni primeri ter izdelane smernice za primerno varovanje kulturne dediščine v izrednih razmerah.

Omenjena projekta bi bilo treba nadaljevati na ravni celotne države ter vključiti tudi dediščino nesakralnega izvora. Vsi ti ukrepi so koristni ne le ob oboroženih spopadih, temveč tudi ob naravnih in drugih nesrečah. 
1. Drugi protokol k Haaški konvenciji o varstvu kulturnih dobrin v primeru oboroženega spopada. https://ihl-databases.icrc.org/applic/ihl/ihl.nsf/ART/590-15?OpenDocument, 7. 4. 2021.

2. Foilant, Y., 2015. Cultural Property Protection Makes Sense: A Way to Improve Your Mission. Haag: Civil-Military Cooperation Centre of Excellence.

3. Furlan, B., Rečnik, D., Vrabič, R., Maraš, V., Cerkovnik, J., Špur, B., Šonc, M., Tušak, M., Ivanuša, M., Gorjup, B., Kojadin, M., Lasič, K., Unger. M., 2006. Vojaška doktrina. Ljubljana: Poveljstvo za doktrino, razvoj, izobraževanje in usposabljanje.

4. Gottlieb, Y., 2020. Attacks Against Cultural Heritage as a Crime Against Humanity. Case Western Reserve Journal of International Law. 52-1, str. 287-330.

5. Guštin, M. (vodja projekta), 2009. Zaključno poročilo o rezultatih opravljenega raziskovalnega dela na projektu ciljnega raziskovalnega programa (CRP) »Znanje za varnost in mir 2006 - 2010«. Koper: Univerza na Primorskem, Znanstveno-raziskovalno središče.

6. Haaški pravilnik o zakonih in običajih vojne na kopnem. https://ihl-databases.icrc.org/ applic/ihl/ihl.nsf/0/1d1726425f6955aec125641e0038bfd6, 4. 8. 2021.

7. Instructions for the Government of Armies of the United states in the Field (Lieber Code). https://ihl-databases.icrc.org/applic/ihl/ihl.nsf/ART/11020035?OpenDocument, 24. 2. 2021.

8. Jogan, S., 2008. Pravno varstvo dediščine. Koper: Založba Annales.

9. Keane, D., 2004. The Failure to Protect Cultural Property in Wartime. DePaul Journal of Art, Technology \& Intellectual Property Law. 14-1, str. 1-38. https:/via.library.depaul. edu/jatip/vol14/iss1/2, 22. 2. 2021.

10. Kladnik, T., 2010. Varovanje (vojaške) kulturne dediščine in civilni nadzor. Bilten Slovenske vojske. 12-3, str. 174-191.

11. Konvencija o varstvu kulturnih dobrin v primeru oboroženega spopada. https://www. zvkds.si/sites/www.zvkds.siffiles/uploads/files/publication/konvencija_o_varstvu_kdvpos. pdf, 9. 3. 2021.

12. Murovec, B. (vodja projekta), 2009. Zaključno poročilo o rezultatih opravljenega raziskovalnega dela na projektu v okviru ciljnega raziskovalnega programa (CRP) "Znanje za varnost in mir 2006-2010«. Ljubljana: ZRC SAZU.

13. O'Keefe, R., 2006. The Protection of Cultural Property in Armed Conflict. Cambridge: Cambridge University Press.

14. O'Keefe R., Péron, C., Musayev, T., Ferrari G., 2016. Protection of Cultural Property, Military Manual. Pariz - Sanremo: UNESCO in International Insitute of Humanitarian Law.

15. Pesu, M., 2012. The Finnish National Inventory: Peacetime preparation for the protection of cultural property in the event of armed conflict. VS. Lambert, ur. in C. Rockwell, ur. Protecting Cultural Heritage in Times of Conflict. Rim: ICCROM, str. 91-96.

16. Pravila službe v Slovenski vojski. http://pisrs.si/Pis.web/pregledPredpisa?id=DRUG2422, 29. 9. 2021.

17. Pravilnik o muzejski dejavnosti v Slovenski vojski, šifra 007-7/2005-1 z dne 16. 11. 2005. Ljubljana: Ministrstvo za obrambo.

18. Rawan, Z., 2017. Great, Greatest or Outstanding: Defining Cultural Property in NATO Operational context. Nato Legal Gazette. 38, str. 100-114.

19. Register kulturne dediščine. https://www.gov.si/teme/register-kulturne-dediscine/, 30. 7. 2021.

20. Rosén, F., 2017a. Nato and Cultural Property: Embracing New Challenges in the Era of Identity Wars. København: CCHAC.

21. Rosén, F., 2017b. NATO-led military Operations and Cultural Property Protection. Nato Legal Gazette. 38, str. 19-27. 
22. Rush, L. W., 2017. The Importance of Training Cultural Property Protection: An Example from the U. S. Army. Nato Legal Gazette. 38, str. 80-91.

23. Senković, S., 2013. Mednarodna zaščita kulturnih dobrin v času oboroženih spopadov. Ljubljana: Univerza v Ljubljani, Pravna fakulteta.

24. Severnoatlantska pogodba. https://nato.gov.si/slo/dokumenti/severnotatlantska-pogodba/, 30. 7. 2021.

25. Sveto pismo Stare in Nove zaveze, 2016. Ljubljana: Svetopisemska družba Slovenije.

26. Turku, H., 2018. The Destruction of Cultural Property as a Weapon of War, ISIS in Syria and Iraq. London: Palgrave Macmillan.

27. Zakon o varstvu kulturne dediščine. http://pisrs.si/ Pis.web/ pregledPredpisa?id=ZAKO4144, 4. 8. 2021.

28. Zidar, A., gl. ur., 2019. Ženevske konvencije in Dopolnilni protokoli, II. del-Protokoli. Ljubljana: MZZ RS in Založba FDV. 


\section{RECENZIJA}

Junija 2021 je pariška založba La Route de la Soie - Éditions izdala monografijo v francoskem jeziku z naslovom »Une géopolitique de la Slovénie«. Avtor je dr. Laurent Hassid, geograf in strokovnjak za meje ter pridruženi raziskovalec na Univerzi Sorbonne Paris Nord v Franciji. Spremno besedo je napisal dr. Barthélémy Courmont, docent na Katoliški univerzi v Lillu v Franciji, ki to monografijo vidi kot priložnost za poglobitev znanja o Sloveniji, še posebej o njeni geografiji, zgodovini in identiteti.

Knjiga obsega 223 strani in je sestavljena iz treh delov. Predstavlja razvoj nekega naroda od jezikovne enotnosti na nekem ozemlju do narodove neodvisnosti (1 Enotnost naroda, 2 - Razlike v narodu in 3 - Od enotnosti v obdobju osamosvajanja do razlik v obdobju članstva v Evropski uniji). V knjigi so predstavljeni geografski, zgodovinski in politični dejavniki, ki so prispevali k razvoju Slovenije kot neodvisne države in ki to državo umeščajo tako v Srednjo Evropo kakor tudi na Balkan in v Sredozemsko regijo. Avtor v sklepnem delu opozori na nekaj izzivov, s katerimi bi se Slovenija morala spoprijeti, če bi postavila pod vprašaj svojo zavezanost evropski ideji in zmožnosti spoprijemanja s sedanjimi in prihodnjimi učinki globalizacije.

Strukturno je monografija razdeljena v tri dele, od katerih ima vsak del od dve do tri poglavja. Nadaljnja členitev v podpoglavja ter opremljenost z zemljevidi, slikami in preglednicami omogočata avtorju, da podkrepi argumentacijo zgodbe in jo predstavi pregledno in berljivo. Člen »une« (»ena« ali »eden izmed«) v naslovu knjige je lahko razumljen v smislu odpiranja možnosti, da interpretacija geopolitike Slovenije, kot jo vidi avtor, ni absolutna, temveč je ena izmed mogočih.

V uvodu avtor naniza nekaj geografskih podatkov o ozemlju Slovenije in jih naveže na zgodovinske dogodke, s čimer pojasni razvoj vzpostavljanja slovenske nacije, ki 
sicer ima svoj jezik in ozemlje, vendar je zgodovinsko brez državotvorne tradicije. Prvi del zaznamuje opis nastanka in razvoja slovenskega naroda. Ta proces je neločljivo povezan z nastankom prvih knjižnih del v slovenskem jeziku v 16. stoletju, s čimer so se po avtorjevo vzpostavili temelji za narodno prebujanje v naslednjih stoletjih. Zgodovino Karantanije in Celjskih grofov (knezov) vidi kot del mitologije, ki je pomembno prispevala k oblikovanju državotvorne zavesti v 19. in 20. stoletju. Drugi del knjige se osredotoča na razlike in izzive mlade države. Predstavljeni so zgodovinske dežele, pokrajine, njena narečja in narodne manjšine. Dotakne se tudi tematike slovenske diaspore in tistih, ki so po rodu iz drugih republik nekdanje Jugoslavije, ter razmerij in odnosa večinskega prebivalstva do njih. Tretji del govori o političnem razvoju od konca 80 . let prejšnjega stoletja do poosamosvojitvenega obdobja. Avtor to deli v tri obdobja. Prvo poimenuje obdobje narodne enotnosti (od začetka 80. let do leta 1992), drugo imenuje obdobje stabilnosti, ki traja 20 let (od leta 1992 do 2011). Tretje obdobje, imenovano čas politične nestabilnosti, se začne z letom 2011 in traja do vključno izida knjige leta 2021. Avtor predstavi tudi sodoben slovenski politični sistem, glavne politične osebnosti in dogodke. Monografija se konča s kratkim premislekom o morebitnih izzivih Slovenije v prihodnosti.

To delo je pomemben prispevek $\mathrm{k}$ zelo redki literaturi $\mathrm{v}$ francoskem jeziku na temo geopolitike Slovenije. Vzrok je verjetno to, da na ozemlju Slovenije pred letom 1991 nikoli ni bilo samostojne države in je bilo to obravnavano kot del avstrijskega, italijanskega ali jugoslovanskega oziroma balkanskega geopolitičnega konteksta. To je opazil tudi pisec spremne besede Barthélémy Courmont, ki navede, da je v 90. letih prejšnjega stoletja nekajkrat prečkal Slovenijo, ne da bi se tega dobro tudi zavedal. Podobne vzporednice je mogoče potegniti z geopolitično uspešnico Balkanski duhovi ${ }^{1}$, v kateri avtor Robert Kaplan opisuje prečkanje jugoslovanskoavstrijske meje in prihod v Zagreb konec 80. let, ne da bi vmes zaznal ali opisal kakršnokoli ozemlje ali (geo)politično tvorbo.

Časovno izid knjige sovpada z dvema ključnima geopolitičnima trenutkoma iz slovenske zgodovine. Junija 2021 je Slovenija praznovala 30 let samostojnosti in neodvisnega nastopanja v mednarodnem diplomatskem okolju. Drugi ključni dogodek zaznamuje stoletnico vidovdanske ustave junija 1921, ki je pravno konsolidirala Kraljevino Srbov, Hrvatov in Slovencev, hkrati pa končala obdobje prvega samostojnega pojavljanja Slovencev na geopolitični šahovnici, ki se je začelo oktobra 1918.

Monografija združuje pomembno število geografskih, jezikovnih, kulturnih in večinoma sodobnih političnih podatkov in dogodkov, ki pomagajo vzpostaviti sliko slovenske (geo)politične krajine. Vse to tudi pomaga pojasniti nastanek slovenskega naroda in njegov razvoj do samostojne in neodvisne nacije. Glede na to, da je več kot četrtina knjige posvečena sodobni slovenski politiki in z njo povezanim

»Balkan Ghosts: A Journey Through History«, prvič objavljena leta 1993, je geopolitična uspešnica ameriškega avtorja Roberta D. Kaplana. 
geopolitičnim dogodkom², dobi bralec dober vpogled v dogodke, povezane s prvimi tremi desetletji slovenske neodvisnosti.

Česar ta knjiga bralcu ne ponuja, še posebej to velja za francosko govoreče bralce, je geostrateška analiza. Avtor na kratko povzema obdobje Napoleonovih Ilirskih provinc in ilirskega gibanja, vendar ne poda nobene ocene strateškega vpliva Francije ali drugih velikih sil na te dogodke na slovenskem ozemlju. Še posebej manjka opis vzrokov in strateškega ozadja francoske ustanovitve Ilirskih provinc (1809-1813) ter vloge Francije pri oblikovanju versajske Jugoslavije v letih 1918-19. Analiza vpliva Francije na oblikovanje slovenskih meja z Avstrijo in Italijo ${ }^{3}$, pa tudi trenutna in prihodnja pozicija Francije vis-a-vis Slovenije in regije, ki ji ta pripada, bi bili dobrodošli.

Naj končamo z mislijo, da monografija avtorja dr. Laurenta Hassida Une géopolitique de la Slovénie ponuja predvsem francosko govorečemu občinstvu dober vpogled v geografijo, identiteto in zgodovino Slovenije. Prav tako odpira vrata za nadaljnje raziskovanje in pisanje o geopolitiki Slovenije v francoskem jeziku. Za vse tiste, ki iz osebnih ali pa strokovnih vzgibov želijo izvedeti več o Sloveniji, ponuja ta knjiga solidno osnovo. Slovenskemu akademskemu svetu pa knjiga odstira vpogled v to, kako je slovenski geopolitičen kontekst viden skozi prizmo tujega, v tem primeru francoskega, avtorja, kar lahko spodbudi zanimanje za prihodnja dela na to temo, dostopna tudi tujemu občinstvu.

V glavnem osredotočenih na definiranje meje s Hrvaško in na migrantsko problematiko od leta 2015.

3 Na primer predstavitev zemljevidov in geostrateškega ozadja francoskih, pa tudi drugih razmejitvenih predlogov z Avstrijo leta 1919 in Italijo v letih 1945-47. 


\section{REVIEW}

Published in June 2021 by La Route de la Soie - Éditions, 'Une géopolitique de la Slovénie' (A Geopolitics of Slovenia) by Laurent Hassid PhD is a monograph in French on the geopolitics of Slovenia. The author is an associated researcher at the Université Sorbonne Paris Nord in France, specializing in geography and borders. The foreword by Barthélémy Courmont $\mathrm{PhD}$, Assistant Professor at the Catholic University in Lille, France, introduces the book as an opportunity for the reader to expand their knowledge about Slovenia by obtaining an insight into its geography, history and identity.

Indeed, the 223-page monograph is structured in three parts following the destiny of Slovenia from a community of a language to an independent nation (1: Unity of a nation; 2: Diversity of a nation; and 3: From unity during independence to the division of an European state). From introduction to conclusion the author looks at the geographical, historical, and political factors that led to the emergence of Slovenia as a sovereign state, which can at the same time be seen as belonging to Central Europe, the Balkans, and the Mediterranean region. The conclusion points only briefly to some challenges which could put into question the European commitments of the country and its ability to face the current and upcoming effects of globalization.

The storyline develops gradually from parts one to three, which are broken down into two to three chapters each. The multiple headings within the chapters, and the various maps, pictures and tables which underpin the argumentation, render the book reader-friendly. The article "une" (in English " $a$ ") in the book's title seems to suggest that this monograph touches upon one of several possible ways of looking at the geopolitics of Slovenia. 
In particular, the introduction outlines the geographical features of the Slovene territory and refers to several historic facts which explain the state-building process of a nation with its own language and territory, but without any particular statehood history. The first part portrays the emergence and evolution of the Slovene nation. This is closely associated with the Slovene literature of the 16th century and onwards, which laid the foundations of a national awakening. The author refers to the history of Carantania and the Counts (Dukes) of Celje as myths that played a significant part in the nation and state-building process of the 19th and 20th centuries. The second part of the book focuses on the differences and challenges within the young country. It describes the historical regions and their dialects, and touches upon the composition of minorities, the Slovene diaspora, and the various ex-Yugoslav nationalities living in Slovenia and their relationships with the native Slovenes. The third part talks about the political developments of the late 1980s and of the postindependence period. The author describes the late 1980s up to 1992 as a time of national unity, which was followed by 20 years of political stability (from 1992 to 2011). Since 2011, he considers that Slovenia has been confronted by an emerging political instability. He offers a snapshot of the contemporary political system, and the main political personalities and events. The book ends with a short reflection of the potential challenges ahead for Slovenia.

The book is a welcome addition to monographs written in French. The scarce literature dedicated to Slovenia and its geopolitics is most likely due to the fact that Slovene territory had not been independent historically before 1991. If ever mentioned, it was within the Austrian, Italian, or Yugoslav (Balkan) geopolitical context. In his preface to the book, Barthélémy Courmont indicates this when mentioning that he crossed Slovenia a few times in the early 1990s without even realizing it. This observation is very similar to the one made by Robert Kaplan in his geopolitical bestseller, Balkan Ghosts ${ }^{1}$, where he explains how he crossed the Yugoslav-Austrian border and came to Zagreb (Croatia) in the late 1980s, without noticing any territory or (geo)political entity in between.

Timewise, its publication coincides with the anniversaries of two key geopolitical moments in Slovene history. June 2021 marks 30 years since Slovenia became a sovereign and independent state and a full member of the international community. It is also the anniversary of the "Vidovdan" constitution of June 1921, which consecrated the Kingdom of Serbs, Croats and Slovenes; it put an end to the very first independent appearance of Slovenes on the geopolitical chessboard, which had begun in October 1918.

This monograph assembles an important amount of geographic, linguistic, cultural and (mostly contemporary) political data and events, which together help to understand the geo(political) landscape of Slovenia. These also explain, in the view

Balkan Ghosts: A Journey Through History, first published in 1993, is a geopolitical bestseller written by US author Robert D. Kaplan. 
of the author of the monograph, the birth of the Slovene nation and its development into an independent country. As more than a quarter of the book is focused on contemporary Slovene politics and related actual (geo)political events ${ }^{2}$, the reader can get a sound insight of the first three decades since Slovenia's independence.

What the book does not provide to the reader, and in particular to the French-speaking audience, is a geostrategic analysis. The author refers briefly to the Napoleonian Illyrian provinces and the Illyrian movement, but he falls short of offering any assessment of the strategic impact of France or other main powers with regard to this territory. One might have expected a closer look at France's strategic reasons for establishing the Illyrian provinces (1809-13), and at its role in the formation of the Versailles Yugoslavia in 1918-19. The involvement of France in the drawing of the Slovene borders with Austria and Italy ${ }^{3}$, and its current and future strategic stance with regard to Slovenia and the region it belongs to, would have also deserved further consideration.

All in all, Une géopolitique de la Slovénie has the merit of offering to the reader, especially to the francophone one, an insight into the geography, identity, and history of Slovenia. It could be a reference for future writing on this young country. It offers a starting point to those who wish to learn more about Slovenia, be it for professional or personal reasons. To Slovene academia, the book provides an insight into how the overall Slovene geopolitical context is perceived through the lens of a foreign (French) author, and it may generate an interest in future writing on this topic accessible to foreign readers.

Mainly focused on defining the border with Croatia and the issue of migrations since 2015.

For example, presenting maps and the geostrategic background of France's (as well as other Great Powers') border proposals with Austria in 1919 and with Italy in 1945-47. 


\section{RECENZIJA}

Francoska založba L'Harmattan je leta 2021 izdala monografijo z naslovom Darfur peacekeepers the African union peacekeeping mission in Darfur (AMIS) from the perspective of a Hungarian military advisor (Mirovniki v Darfurju, misija Afriške unije v Darfurju (AMIS) iz perspektive madžarskega vojaškega svetovalca).

Avtor monografije, ki obsega 234 strani, je Janos Besenyo. Poleg uvoda in zaključka je v njej še šest vsebinskih poglavij. V prvem z naslovom Geografija in zgodovina Darfurja avtor predstavi geografijo, podnebje, floro in favno, večja mesta, ekonomijo, infrastrukturo, različne narodnosti, etnične skupine in verstva ter zgodovino Darfurja.

V drugem z naslovom AMIS se osredotoči na mirovno misijo Afriške unije v Sudanu ali na kratko AMIS I, v katerem predstavi razloge za konflikt v Darfurju, njegov izbruh in vključitev Afriške unije v konflikt z misijo, poimenovano Afriška unija v Sudanu.

Sledi poglavje z naslovom AMIS II, v katerem predstavi zgodovino, strukturo in operacijo po odločitvi o angažiranju dodatnih civilnih in vojaških opazovalcev, vojakov, policistov in dodatnih finančnih ter drugih sredstev.

V četrtem poglavju je predstavljena nova misija, poimenovana AMIS II E ali AMIS III, po kateri je to poglavje tudi poimenovano. Kratica E je za angleško besedo »enhanced«, kar je za to misijo pomenilo okrepljeno vojaško prisotnost. V tem poglavju je podpoglavje, $\mathrm{v}$ katerem so opisani znanilci neuspeha in dodatno angažiranje Organizacije združenih narodov, čemur je sledila misija OZN-a in Afriške unije v Darfurju, poznana pod kratico UNAMID. 
$\mathrm{V}$ petem poglavju $\mathrm{z}$ naslovom Podporna misija Evropske unije avtor $\mathrm{v}$ štirih vsebinskih podpoglavjih predstavi več faz sodelovanja Evropske unije na misiji, katere nosilka je Afriška unija. V šestem poglavju z naslovom Madžarske izkušnje so opisane izkušnje Madžarov z misij v Darfurju. Svojega vojaškega opazovalca je Madžarska v Darfur prvič napotila leta 2004.

Vključitev Madžarske v misijo v Afriki se zdi nenavadna, saj je bila med vsemi sodelujočimi državami edina, ki v tem delu sveta ni imela kolonialne zgodovine, ekonomskih ali kakšnih drugih interesov, hkrati pa tudi nobenih predhodnih izkušenj. Monografija ima samo eno pomanjkljivost, in sicer to, da ni znanstvena. Navedeno je hkrati tudi njena prednost.

Besenyo je bil častnik madžarske vojske 31 let. V Darfurju je bil v drugi polovici leta 2005. Osebna izkušnja mirovnika ga je zelo zaznamovala, saj od takrat namenja veliko prozornosti varnostnim vsebinam, ki so povezane z Afriko. Njegova vrnitev z misije Afriške unije, Evropske unije, Nata, Združenih narodov in drugih v Darfurju je bila časovno povezana $\mathrm{z}$ njegovim doktorskim študijem. Obe dejavnosti sta dosegli enak učinek kot reki, ki se ob sotočju zlijeta ena v drugo in v nadaljevanju toka pridobita veliko moči in hitrosti.

Avtor monografije se je po končani vojaški karieri kot plodovit pisec in raziskovalec nemirnega duha dejavno vključil $\mathrm{v}$ akademsko okolje kot visokošolski profesor na Univerzi Obuda v Budimpešti. Tam je leta 2019 nastal Raziskovalni inštitut za Afriko v okviru doktorske šole za področje varnosti in varnostnih ved, ki ga vodi docent dr. Besenyo in je glede na količino in kakovost objav z afriškimi vsebinami očitno zelo uspešen.

Z evropskega zornega kota je Afrika celina, ki je zelo daleč, posledice tega, kar se v njej dogaja, pa se vedno bolj tičejo tudi vseh nas v Evropski uniji in njeni okolici. Migracijski val, s katerim je v zadnjem desetletju na obale Sredozemlja prišlo veliko afriških migrantov in ki je vrh dosegel leta 2015, je pomembno spremenil in vplival na vse države na poti, še posebej pa na tiste, ki so jih migranti izbrali kot ciljne.

Ker bi moral vsak imeti pravico mirno živeti na svojem domu, po svoje, v krogu svoje družine, bi bilo prav, da mu je to tudi zagotovljeno. Žal podnebne spremembe, pomanjkanje vode, bolezni, revščina, razlike v kulturi, veri, politični ureditvi in naravnih danostih, včasih pa samo posamezniki ali manjša združenja, pripeljejo do različnih trenj, spopadov ali celo genocida, kot se je to zgodilo v Darfurju. Takrat se navadno vključijo mednarodna humanitarna skupnost ter različne varnostne in druge organizacije, ki hitijo na pomoč nemočnemu prebivalstvu. Besenyo je v svoji monografiji predstavil vso širino in veličino mednarodnih humanitarnih prizadevanj, hkrati pa tudi kruto realnost, ko so vsi, ki želijo pomagati, točno tam, kjer morajo biti, pa so kljub vsem prizadevanjem povsem nemočni. 
Mirovnike Darfurja priporočam v branje vsem, ki jim je pomembna prihodnost nas vseh in naših potomcev, predvsem pa tistim, ki imajo možnost in priložnost vplivati na varnost države, družbe in posameznika. Vsebina knjige je dragocen vpogled v izkušnje vojaškega častnika, iz katerih se vsi lahko veliko naučimo, še največ pa pripadniki oboroženih sil, policije in civilnih ustanov, ki vodijo ali podpirajo delovanje mednarodnih misij. 


\section{REVIEW}

\section{DARFUR PEACEREEPERS}

In 2021, the French publishing house L'Harmattan published a monograph entitled Darfur peacekeepers the African Union peacekeeping mission in Darfur (AMIS) from the perspective of a Hungarian military advisor.

The author of the 234-page monograph is Janos Besenyo. In addition to the author's preface and the conclusion, the monograph includes six substantive chapters. In the first chapter entitled Geography and history of Darfur, the author presents the geography, climate, flora and fauna, major cities, economy, infrastructure, different nationalities, ethnic groups and religions, and the history of Darfur.

In the second chapter, entitled AMIS, he focuses on the African Union's mission in Sudan I (AMIS I), presenting the causes of the Darfur conflict, its outbreak and the African Union's engagement in the conflict with the African Union's mission in Sudan.

This is followed by a chapter entitled AMIS II, which presents the history, structure and operation following the decision to engage additional civilian and military observers, soldiers, police officers and additional financial and other resources.

The fourth chapter presents a new mission called AMIS II E or AMIS III, which is also the title of the chapter. The letter E in the acronym stands for the word "enhanced," which implied the enhanced character of military presence in this mission. This chapter is composed of a subchapter entitled The Foreshadow of the Fall and the additional engagement of the United Nations, followed by the UN and African Union mission in Darfur, known as UNAMID. 
In the fifth chapter, entitled The Support Mission of the European Union, and its four substantive subchapters, the author presents several phases of the European Union's participation in the mission led by the African Union. Chapter six, entitled Hungarian Experience, describes Hungarian experiences from the missions in Darfur. Hungary first deployed its military observer to Darfur in 2004.

Hungary's involvement in the mission in Africa seems unusual, as it was the only one of all the participating countries that had no colonial history, economic or any other interests in this part of the world, and at the same time had no previous experiences. The monograph has only one drawback, and that is the fact that it is not scientific. However, this is at the same time its advantage.

Besenyo was an officer in the Hungarian Armed Forces for 31 years and was deployed in Darfur in the second half of 2005. He was strongly marked by his personal experience as a peacekeeper. Ever since, he has been devoting much attention to Africa-related security topics. His return from the mission of the African Union, the European Union, NATO, the United Nations and other organisations in Darfur coincided with his doctoral studies. Both of these activities have achieved the same effect as two rivers, which merge at the confluence and gain a lot of power and speed as their flow continues.

After completing his military career, the author of the monograph, who is a prolific writer and restless researcher, became actively involved in the academic environment as a university professor at the Obuda University in Budapest. In 2019, the Africa Research Institute was established within the Doctoral School of Safety and Security Sciences, University of Óbuda, headed by Assistant Professor Besenyo, $\mathrm{PhD}$. Considering the amount and quality of publications concerning the African continent, the institute is clearly very successful.

From a European point of view, Africa is a very distant continent; however, the developments in that region and their results are increasingly affecting all of us in the European Union and beyond. The migration flow, which brought many African migrants to the shores of the Mediterranean over the last decade and peaked in 2015, has significantly changed and affected all the countries along their way, especially those that migrants had chosen as their target countries.

Since everyone should have the right to live at home in peace, in their own way, with their family, it would be right that they are enabled to do so. Unfortunately, climate change, water scarcity, disease, poverty, differences in culture, religion, political order and natural resources, but sometimes only individuals or smaller associations, lead to various frictions, conflicts or even genocide, as was the case in Darfur. In such cases, the international humanitarian community and various security and other organizations are usually involved to assist the helpless population. In his monograph, Besenyo presented the full breadth and magnitude of international humanitarian 
efforts, but also the harsh reality where all those who want to help are exactly where they need to be, but despite all their efforts, they are completely powerless.

I recommend Darfur Peacekeepers to be read by all those who care about the future of all of us and our descendants, but especially by those who have the opportunity and ability to influence the security of the country, the society and the individual. The content of the book provides an invaluable insight into the experience of a military officer. It is a valuable learning resource for all of us, but especially for members of the armed forces, police and civilian institutions that lead or support the activities within international missions. 


\section{RECENZIJA}

Generalštab Slovenske vojske je letos izdal monografijo dr. Branimirja Furlana, brigadirja v pokoju ${ }^{2}$, Vojaška strategija. V okviru zbirke Teorija in praksa strategije je po lani izdani Nacionalni (varnostni) strategiji to njegova druga monografija in predstavlja nadaljevanje obravnave teorije in prakse strategije. Za teoretike in praktike strategije sta monografiji znanstveno utemeljen pripomoček za boljše delo. Monografija Vojaška strategija je nastajala skoraj hkrati s procesom vojaškega strateškega premisleka in nastajanja predloga vojaške strategije Slovenije v Slovenski vojski. Ko bodo rezultati tega procesa izdani, bo monografija odličen pripomoček za boljše razumevanje in ocenjevanje njihove vsebine ter njihovo umeščanje $v$ teorijo in prakso.

Monografija je celovito znanstveno delo, smiselno strukturirano v uvod, pet poglavij in sklepne misli. Po uvodu nam avtor v prvem poglavju z uvodom v teorijo vojaške strategije naniza potrebne osnove za proučevanje znanstvenega področja. V drugem poglavju o vojni in vojskovanju predstavi različne poglede na vojno, pravne, etične in moralne vidike vojne in oboroženih konfliktov ter nakaže, kako in kje raziskovati ter kakšna bo prihodnja vojna. Piše o vojskovanju na splošno in o izbranih načinih vojskovanja ter vojskovanju prihodnosti in teoriji zmage. V tretjem poglavju o vojski kot instrumentu nacionalne moči piše o uporabi vojaške moči, značilnosti in učinkovitosti vojske. To je ena prvih obdelav vojaškega instrumenta moči na

\footnotetext{
Brigadir D. Humar je magister znanosti, dela na Generalštabu Slovenske vojske.

2 B. Furlan, upokojeni brigadir Slovenske vojske, je doktoriral na Fakulteti za družbene vede Univerze v Ljubljani, magistriral na vojni fakulteti kopenske vojske ZDA in diplomiral na Tehniški vojaški akademiji kopenske vojske JLA. V svoji karieri je združeval prakso poveljnika in štabnega častnika s pripravo teoretičnih, strokovnih in znanstvenih podlag za delovanje vojske. Ob tem je tudi učil, med drugim strategijo. Zadnjih več kot deset let je delal na generalmajorskih delovnih mestih v Generalštabu SV, Poveljstvu sil SV in na Ministrstvu za obrambo. Delal je tudi v Natovem združenem poveljstvu sil v Neaplju. Tako je med drugim ob proučevanju in oblikovanju strateških rešitev te uveljavljal tudi v praksi.
} 
znanstveni ravni v Sloveniji. V četrtem poglavju o oblikovanju vojaške strategije predstavi poglede na stratege, strateške vodje in strateško razmišljanje, na proces oblikovanja vojaške strategije in strateški koncept ter na vpliv tehnologije na strateški koncept. Predstavi tudi nekatere izzive v procesu oblikovanja vojaške strategije. $\mathrm{V}$ petem poglavju o uresničevanju vojaške strategije predstavi različne zamisli in poglede na vojaško delovanje, obrambno načrtovanje, operativno veščino in vojaško doktrino. V sklepnih mislih poudari pomen vojaškega instrumenta moči, potrebo in nujnost po vojaški strategiji, še posebej v kriznih časih, kar argumentira s primeri iz zgodovine. Poudari, da nas ti primeri spomnijo, da ni nujno, da bo vedno mir, in zato ne bi smeli zanemariti razvoja strateške misli, predvidevanja razvoja prihodnjega varnostnega okolja, ocenjevanja verjetnosti ogrožanja vitalnih slovenskih interesov v prihodnosti in priprave ustreznih strategij, tudi vojaških. To dolgujemo našim naslednikom, ki z vso pravico to od nas tudi pričakujejo.

V knjigi je predstavljen celovit pogled na razvoj in temeljne koncepte vojaške strategije. Razložen je pomen razvojne in operativne razsežnosti vojaške strategije. Knjiga informira in je dober pripomoček o strateškem vojaškem delovanju tudi pripravljavcem drugih strategij, predvsem obrambne, pa tudi vojaških in obrambnih strateških dokumentov. Omogoča razumevanje vojske kot nacionalnega instrumenta moči, kar je pomembno tudi za druge deležnike v nacionalnovarnostnem sistemu, oziroma nosilcem instrumentov nacionalnih moči. Ob tem je ustrezna pozornost namenjena tudi odnosu med vojaško strategijo in politiko. Avtor ugotavlja, da v civilno-vojaškem dialogu na koncu odločajo civilne avtoritete, kar navadno obsega tudi odobritev vojaške strategije, čeprav gre za vojaški strokovni dokument. To je še posebej pomembno, ker v sodobnem svetu uporabo vojaške sile povezujemo $\mathrm{z}$ uporabo različnih instrumentov nacionalne moči. Vojaška strategija mora biti zato proizvod civilno-vojaškega vzajemnega delovanja.

Delo je zahtevno z navajanjem številnih pomembnih in prepletajočih se zamisli različnih avtorjev, ki pa jih avtor velikokrat ne komentira in ne vrednoti. Tako prihodnjim teoretikom in raziskovalcem predstavlja dobro raziskovalno izhodišče. Avtor ugotavlja, da ni nujno vsaka vojaška strategija javno prepoznavna in formalizirana. Mogoče zato ne ponuja izrecnih rešitev, kar pa zahteva strateško razmišljanje bralca pri uporabi različnih zamisli. Tako ima avtor bolj ambicijo prispevati $h$ kritičnemu mišljenju oblikovalcev konkretnih strategij. Tak pristop zahteva od uporabnika veliko znanja, kar nakazuje tudi ta knjiga.

Čeprav avtor trdi, da je to delo aplikativno naravnano, je predvsem v vlogi strateškega procesa in zahteva od bralca poglobljen študijski pristop. Bralec lahko pridobi odgovore predvsem na vprašanja, kaj je vojaška strategija, kakšen je njen namen in zakaj jo potrebujemo, kdo jo oblikuje, kako se do nje pride, kaj jo naredi uspešno, kateri izzivi se pojavljajo med oblikovanjem strategije in kaj je potrebno, da se lahko strategija uresničuje. 
Monografija nakazuje poti, kako in kje si pridobiti kompetence za dobrega vojaškega stratega, a hkrati odpira več vprašanj, kot ponuja rešitev, predvsem za delovanje vojske, kot je slovenska. Tako spodbuja k proučevanju teorije in prakse, s čimer se lahko strateško utrjuje tudi vojaška misel.

Avtor si prizadeva uporabljati slovensko izrazoslovje in utemeljuje pomembne koncepte in termine za vojsko ter znanstveno področje vojaške strategije. V monografiji je veliko slovenskih strokovnih terminov. Nekateri, kot na primer vojska/vojaška sila/oborožena sila, moč vojske/vojskovalna moč/instrumenti moči, vojskovanje/bojevanje, operativna veščina/operatika niso povsem pojasnjeni. Kljub temu monografija ob vsebinskih zapolnjuje tudi terminološke vrzeli in tako spodbuja tudi praktično rabo slovenske terminologije na področju vojaške strategije.

Z znanstveno utemeljitvijo in povezavo teorije in realnosti je dr. Furlan pokazal smer, med drugimi tudi vojaškim častnikom, za krepitev strateške misli ter oblikovanje in udejanjanje vojaške strategije. Knjiga bo za slovenske vojake, predvsem tiste častnike, ki so nosilci razvoja in uporabe vojske na strateški ravni, naravni pripomoček. Ob tem ni nič manj dobrodošla vsem, ki se ukvarjajo s strategijo nacionalne varnosti, vključno s političnimi odločevalci.

Strategija je na splošno pot oblikovanja, za majhne države oziroma vojske pa iskanja ugodnega vojaškega strateškega položaja. To iskanje je za častnike in generale na strateški ravni eno temeljnih poslanstev, pri čemer nam monografija lahko zelo pomaga. Upamo, da nam bo dr. Furlan pri tem pomagal tudi v prihodnje. 


\section{REVIEW}

This year, the General Staff of the Slovenian Armed Forces issued the monograph Vojaška strategija (Military Strategy) by Branimir Furlan, PhD, a retired Brigadier General $^{2}$. After the Nacionalna (varnostna) strategija (National (Security) Strategy), issued last year under the collection Teorija in praksa strategije (The Theory and Practice of Strategy), this is his second monograph issued under the same collection. It is a continuation of the discussed theory and practice of strategy. Both monographs can serve as science-based tools for the better work of theoreticians and practitioners. The monograph Vojaška strategija was written almost in parallel with the process of military strategic consideration and the drafting of Slovenian military strategy within the Slovenian Armed Forces. Once the results of this process are issued, the monograph will be an excellent tool for a better understanding and assessment of their content, and their implementation in theory and practice.

The monograph is a comprehensive scientific work with a logical structure: an introduction, five chapters and a conclusion. In the first chapter following the introduction, which acquaints us with the theory of military strategy, the author states the required bases for the study of this scientific field. In the second chapter on war and warfare, the author presents the different views on war and the legal, ethical

\footnotetext{
Brigadier General D. Humar is a Master of Science, employed at the General Staff of the Slovenian Armed Forces.

2 Branimir Furlan, retired Brigadier General of the Slovenian Armed Forces, obtained his PhD at the Faculty of Social Sciences of the University of Ljubljana. He obtained his Master's degree at the US Army War College and his diploma thesis at the Military Technical Academy of the Yugoslav People's Army. During his career, he merged his practical work as a commander and staff officer with the preparation of theoretical, professional and scientific bases for the operation of the military. He also held lectures, among other things, on strategy. In the last more than ten years, he assumed posts of the rank of Major-General in the General Staff of the Slovenian Armed Forces (SAF), the SAF Force Command, and the Ministry of Defence. He also worked at the Allied Joint Force Command in Naples. Among other things, he not only studied and developed strategic solutions, but also applied them in practice.
} 
and moral aspects of war and of armed conflict, and indicates how and where to carry out research and what future wars will look like. The author writes about warfare in general, selected means of warfare, the warfare of the future, and the theory of victory. In the third chapter, in which he addresses the military as an instrument of national power, the author writes about the use of military power and the characteristics and effectiveness of the military. In the Slovenian environment, this is the first time that a military instrument of power has been addressed at a scientific level. In the fourth chapter, on the formation of military strategy, he presents his view on strategists, strategic leaders and strategic thinking, on the process of developing military strategy, on the strategic concept, and on the impact of technology on the strategic concept. He also presents certain challenges in the process of developing military strategy. In the fifth chapter, which addresses the implementation of military strategy, the author presents the different concepts of and views on military operation, defence planning, operational skill, and military doctrine. In the conclusion, the author underlines the importance of the military instrument of power and the need as well as the necessity for military strategy, especially in times of crisis, and supports his statements with examples from history. He stresses that these examples should serve as a reminder that peace must not be taken for granted and that we should thus not neglect the development of strategic thought, the anticipation of the development of the future security environment, the assessment of the likelihood of the risk posed to vital Slovenian interests in the future, and the preparation of relevant strategies, including the military strategy. We owe this to our successors who rightfully expect it.

The book provides a comprehensive view of the development and the fundamental concepts of military strategy. It explains the significance of the developmental and operational dimension of military strategy. It is informative and a good tool for strategic military operation, including for the developers of other strategies, especially the defence strategy, as well as of military and strategic documents. It helps the understanding of the military as a national instrument of power, which is also important for other stakeholders in the national security system or for the holders of the instruments of national power. At the same time, the book affords relevant attention to the relationship between military strategy and politics. The author notes that it is the civilian authorities who are the final decision-makers in the civilmilitary dialogue, which usually includes the authorization of military strategy even though the strategy is a professional military document. This is especially important because, in the modern world, we tend to connect the use of military force with the use of different instruments of national power. Military strategy must therefore be a product of civil-military interaction.

The work is challenging; it contains citations of numerous important and intertwining concepts by different authors, which the author, more often than not, neither comments on nor assesses. The work thus represents a good research starting point for future theoreticians and researchers. The author establishes that not all military strategies are necessarily publically recognized or formalized. This may be the reason why the book does not offer explicit solutions, but rather requires the reader's strategic 
thinking in trying to apply the different concepts. It therefore seems that the author's ambition is to contribute to the critical thinking of the developers of actual strategies. Such an approach demands a great deal of knowledge on the side of the user, which is also reflected in this book.

Although the author claims that the work is application-oriented, it mainly supports the strategic process and requires an in-depth study approach from the reader. The reader can obtain answers primarily to the following questions: What is military strategy?; What is its purpose and why do we need it?; Who develops the military strategy?; How do we obtain it?; What makes it successful?; Which challenges appear during the development of the strategy?; and What is required for the strategy to be implemented?

The monograph suggests how and where to gain competencies for good military strategists, but at the same time opens more questions than it provides answers to, especially for the operation of a military such as the Slovenian Armed Forces. It encourages the study of theory and practice through which it can also contribute to the strategic reinforcement of military thought.

The author strives to use Slovenian terminology and substantiates concepts and terms that are relevant to the military and the scientific field of military strategy. The monograph includes a lot of Slovenian terms. Some, such as vojska (military)/ vojaška sila (military force)/oborožena sila (armed forces), moč vojske (military power)/vojskovalna moč (fighting power)/instrumenti moči (instrument of power), vojskovanje (warfare)/bojevanje (conduct of battle), and operativna veščina (operational skill)/(operational art) are not fully explained. In spite of this, the monograph fills not only content gaps but also terminological gaps, thus encouraging the use of Slovenian terminology in the field of military strategy.

With scientific justification and the intertwining of theory and reality, Dr Furlan has shown a direction, to military officers among others, for the reinforcement of strategic thought and the formation and implementation of military strategy. The book will be reference material for Slovenian soldiers, in particularly those officers who are responsible for the development and use of the military at a strategic level. At the same time, it is no less welcome to all those who are involved in the national security strategy, including the political decision-makers.

Generally speaking, a strategy is a path of development of a favourable military strategic position, for small states or the military, while on the other hand, it is a path of searching for a favourable strategic military position. For officers and generals at the strategic level, this search is one of the basic missions for which this monograph can be of great use. We hope that Dr Furlan will be able to support us in this also in the future. 
Avtorji

Authors 


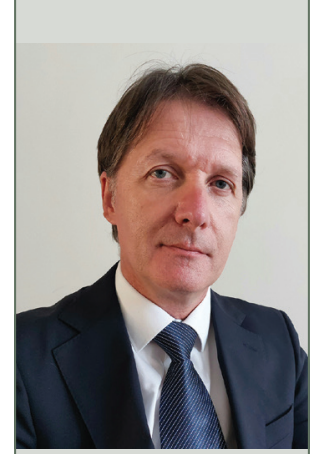

Bruno Blažina

Dr. Bruno Blažina je višji kriminalistični svetnik, zaposlen na Ministrstvu za notranje zadeve v Upravi kriminalistične policije. Trenutno službuje kot uradnik za zvezo pri Evropskem policijskem uradu - Europolu v Den Haagu na Nizozemskem. Magistriral je na Fakulteti za evropske in državne študije in doktoriral na Fakulteti za varnostne vede Univerze v Mariboru z disertacijo z naslovom Strukturna analiza samomorov V slovenski policiji. Blažina je diplomant Nacionalne akademije FBI (Quantico, ZDA).

Bruno Blažina, PhD, is a senior criminal police superintendent employed at the Criminal Police Directorate of the Ministry of the Interior. He currently works as liaison officer at the European Police Office - EUROPOL in The Hague, the Netherlands. He holds a master's degree from the Faculty of Government and European Studies, and a PhD from the Faculty of Criminal Justice and Security, University of Maribor. His PhD thesis is entitled A structural analysis of suicides in the Slovenian police. Blažina is a graduate of the FBI National Academy (Quantico, USA).

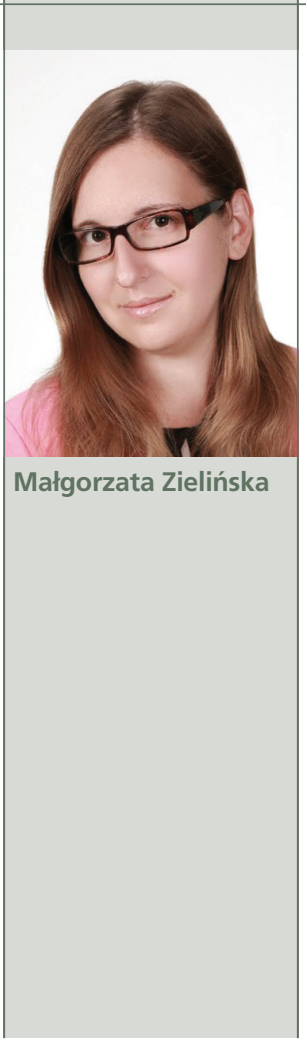

Dr. Małgorzata Zielíńska je ekonomistka in strokovnjakinja za družbene raziskave $v$ vojaškem uradu za družbene raziskave Vojaškega centra za državljansko vzgojo. Diplomirala je iz upravljanja in trženja na fakulteti za ekonomijo v Varšavi in doktorirala iz menedžmenta $\mathrm{z}$ disertacijo z naslovom Strategija upravljanja talentov v poljskih zračnih silah. Na znanstvenem področju se osredotoča na vojaško upravljanje, upravljanje človeškega kapitala ter sociološko in psihološko upravljanje v vojski.

Małgorzata Zielińska, PhD, is an economist and social research specialist at Military Office of Social Research in the Military Center for Civic Education. She graduated in management and marketing from the Warsaw School of Economics and holds a PhD in Management sciences (the title of her dissertation - "Talent Management Strategy in the Polish Air Forces"). Scientifically, she focuses on military management, human capital management, sociological and psychological management sciences in the Army. 


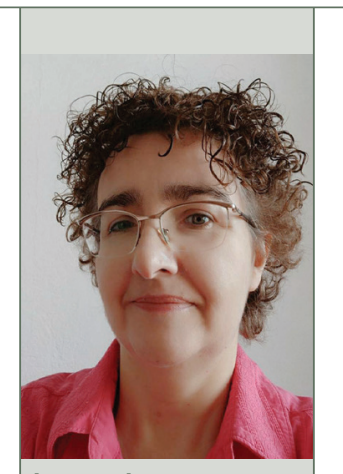

Joanna Łatacz je psihologinja in višja strokovnjakinja $\mathrm{v}$ vojaškem uradu za družbene raziskave Vojaškega centra za državljansko vzgojo. Pri svojem raziskovanju se osredotoča na družbene procese v poljskih oboroženih silah, v katerih ima dolgoletne izkušnje. Zanimata jo predvsem vodenje v vojski in ocenjevanje medijskih sporočil. Med drugim jo zanimajo tudi medkulturne razlike in potovanja, begunci in migracije iz afriških držav ter afriška in korejska glasba.

Joanna Łatacz, psychologist, is a senior specialist at the Military Office of Social Research Military Center for Civic Education. In her research, she focuses on social processes in the Polish Armed Forces, where she has many years of experience. She is mainly interested in leadership in the military, and the evaluation of media messages. Her other interests include intercultural differences and travels, refugees and migration from African countries, African and Korean music.

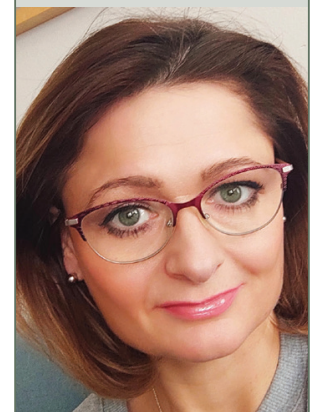

Joanna Zauer

Joanna Zauer je sociologinja. Zaključila je podiplomski študij evropskih integracij in varnosti ter zaščite ljudi v delovnem okolju. Zaposlena je bila kot univerzitetna predavateljica in koordinatorica projektov za raziskave in pripravništvo, ki so se sofinancirali iz evropskih sredstev. Kot višja strokovnjakinja v vojaškem uradu za družbene raziskave Vojaškega centra za državljansko vzgojo je odgovorna za kvantitativne in kvalitativne raziskave v poljskih oboroženih silah. Posebej jo zanimajo finančni, socialni in poklicni položaj vojakov ter zaposlenih na Ministrstvu za nacionalno obrambo.

Joanna Zauer is a sociologist. She graduated in European Integration as well as Safety and Human Protection in the Work Environment. She worked at universities as an academic teacher and coordinator of research and internship projects co-financed from European funds. As a senior specialist at the Military Office of Social Research in the Military Centre for Civic Education she is responsible for quantitative and qualitative research in the Polish Armed Forces. Her particular interests include the financial, social and professional situation of soldiers and employees of the Ministry of National Defence. 


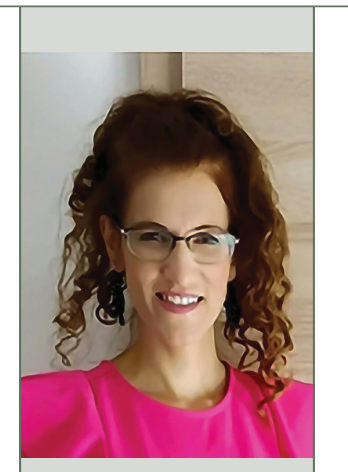

Gabriella Ráczkevy-Deák je diplomirana biologinja. Zaposlena je kot medicinska sestra in ima več kot petnajst let delovnih izkušenj v zdravstvu v Romuniji in na Madžarskem. Študij je nadaljevala na področju varnostnih in obrambnih politik. Trenutno je doktorska študentka na doktorski šoli varnostnih ved na Univerzi Obuda v Budimpešti. Raziskovalne teme, ki jo zanimajo, so varnost bolnišnic, nasilje na delovnem mestu v zdravstvenem sektorju, bolnišnice in terorizem.

Gabriella Ráczkevy-Deák
Gabriella Ráczkevy-Deák holds a bachelor's degree in biology and works as a nurse. She has over fifteen years of healthcare experiences in Romania and Hungary. Continuing her studies in the field of security and defence policies, she is currently a PhD student at Security Sciences Doctoral School in Óbuda University Budapest. Her research interests include hospital security, workplace violence in healthcare, hospitals and terrorism.

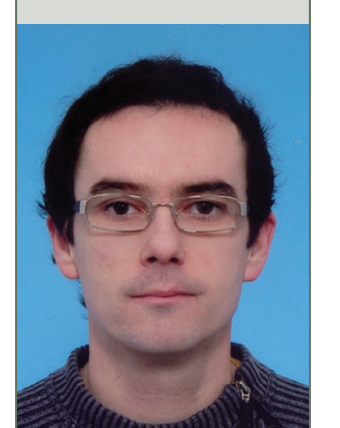

Rok Filipčič
Rok Filipčič je leta 2005 diplomiral na Oddelku za zgodovino Filozofske fakultete v Ljubljani. Leta 2008 se je zaposlil v Vojaškem muzeju Slovenske vojske, kjer je višji kustos. Raziskuje pripravo na vojno in vojno v Sloveniji v letih 1990 in 1991 ter kulturno dediščino in njeno varovanje med oboroženimi spopadi. Je soavtor monografije Vojaška obramba Slovenije 1990-1991. Udeležil se je mednarodnih vojaških vaj Double river 2019 in Trident Jupiter 2019, na katerih je bil odgovoren za varovanje kulturnih dobrin.

Rok Filipčič graduated in 2005 from the Department of History of the Faculty of Arts in Ljubljana. In 2008, he joined the Military Museum of the Slovenian Armed Forces, where he works as a senior curator. In his research, he focuses on war preparations and war in Slovenia in 1990 and 1991, and cultural heritage and its protection during armed conflicts. He is co-author of the monograph Vojaška obramba Slovenije 1990-1991 (Military defence of Slovenia 1990-1991). He participated in the multinational military exercises Double River 2019 and Trident Jupiter 2019, where he was responsible for the protection of cultural property. 
Navodila za avtorje

\section{Instructions to authors}




\section{NAVODILA ZA AVTORJE}

\section{Vsebinska navodila}

Splošno

Sodobni vojaški izzivi je interdisciplinarna znanstveno-strokovna publikacija, ki objavlja prispevke o aktualnih temah, raziskavah, znanstvenih in strokovnih razpravah, tehničnih ali družboslovnih analizah z varnostnega, obrambnega in vojaškega področja ter recenzije znanstvenih in strokovnih monografij (prikaz knjige).

Vojaškošolski zbornik je vojaškostrokovna in informativna publikacija, namenjena izobraževanju in obveščanju o dosežkih ter izkušnjah na področju vojaškega izobraževanja, usposabljanja in izpopolnjevanja.

Vsebina Objavljamo prispevke v slovenskem jeziku s povzetki, prevedenimi v angleški jezik, in po odločitvi uredniškega odbora prispevke v angleškem jeziku s povzetki, prevedenimi v slovenski jezik.

Objavljamo prispevke, ki še niso bili objavljeni ali poslani v objavo drugi reviji. Pisec je odgovoren za vse morebitne kršitve avtorskih pravic. Če je bil prispevek že natisnjen drugje, poslan v objavo ali predstavljen na strokovni konferenci, naj to avtor sporoči uredniku in pridobi soglasje založnika (če je treba) ter navede razloge za ponovno objavo.

\section{Tehnična navodila}

Dolžina Praviloma naj bo obseg prispevka 16 strani ali 30.000 znakov s presledki prispevka (ena avtorska pola). Najmanjši dovoljeni obseg je 8 strani ali 15.000 znakov s presledki, največji pa 24 strani oziroma 45.000 znakov.

Recenzija znanstvene in strokovne monografije (prikaz knjige) naj obsega največ 3000 znakov s presledki.

Recenzije Prispevki se recenzirajo. Recenzija je anonimna. Glede na oceno recenzentov uredniški odbor ali urednik prispevek sprejme, nato pa, če je treba, zahteva popravke ali ga zavrne. Pripombe recenzentov avtor vnese v prispevek.

Zaradi anonimnega recenzentskega postopka je treba prvo stran in vsebino oblikovati tako, da identiteta avtorja ni prepoznavna.

Končno klasifikacijo določi uredniški odbor.

Lektoriranje Lektoriranje besedil je zagotovljeno v okviru publikacije. Lektorirana besedila se vrnejo avtorjem v avtorizacijo. 
Navajanje Navajanje avtorjev je skrajno zgoraj, levo poravnano.

avtorjev Primer:

prispevka Ime 1 Priimek 1, Ime 2 Priimek 2

Naslov Navedbi avtorjev sledi naslov prispevka. Črke v naslovu so velike 16 pik, natiprispevka snjene krepko, besedilo naslova pa poravnano na sredini.

Povzetek Prispevku mora biti dodan povzetek, ki obsega največ 800 znakov (10 vrstic). Povzetek naj na kratko opredeli temo prispevka, predvsem naj povzame rezultate in ugotovitve. Splošne ugotovitve in misli ne spadajo v povzetek, temveč v uvod.

Povzetek Avtorji morajo oddati tudi prevod povzetka v angleščino. Tudi za prevod povzetka v angleščini velja omejitev do 800 znakov (10 vrstic). Izjemoma se prevajanje povzetka in ključnih besed zagotovi v okviru publikacije.

Ključne Ključne besede (3-5, tudi $\mathrm{v}$ angleškem jeziku) naj bodo natisnjene krepko in $\mathrm{z}$ besede obojestransko poravnavo besedila.

Oblikovanje Avtorji besedilo oblikujejo s presledkom med vrsticami 1,5 in velikostjo črk besedila 12 pik, pisava Arial. Besedilo naj bo obojestransko poravnano, brez umikov na začetku odstavka.

Predstavitev Avtorji morajo pripraviti kratko predstavitev svojega strokovnega oziroma znanavtorjev stvenega dela. Predstavitev naj ne presega 600 znakov s presledki (10 vrstic, 80 besed). Avtorji naj besedilo umestijo na konec prispevka, po navedeni literaturi.

Struktu- $\quad$ Posamezna poglavja v besedilu naj bodo ločena s samostojnimi podnaslovi in riranje besedila ustrezno oštevilčena (členitev največ na 4 ravni).

Primer:

1 Uvod

2 Naslov poglavja (1. raven)

2.1 Podnaslov (2. raven)

2.1.1 Podnaslov (3. raven)

2.1.1.1 Podnaslov (4. raven)

Oblikovanje V seznamu literature je treba po abecednem redu navesti le avtorje, na katere seznama se sklicujete v prispevku, celotna oznaka vira pa mora biti skladna s harvardliterature skim načinom navajanja. Če je avtorjev več, navedemo vse, kot so navedeni na izvirnem delu.

Primeri:

a) knjiga:

Priimek, ime (začetnica imena), letnica. Naslov dela. Kraj: Založba.

Na primer: Urlich, W., 1983. Critical Heuristics of Social Planning. Chicago:

University of Chicago Press. 
b) zbornik:

Samson, C., 1970. Problems of information studies in history. S. Stone, ur. Humanities information research. Sheffield: CRUS, 1980, str. 44-68. Pri posameznih člankih v zbornikih na koncu posameznega vira navedemo strani, na katerih je članek, na primer:

c) članek $v$ reviji

Kolega, N., 2006. Slovenian coast sea flood risk. Acta geographica Slovenica. 46-2, str. $143-167$.

Navajanje Vse reference se začenjajo enako kot pri natisnjenih virih, le da običajnemu delu virov z

interneta sledi še podatek o tem, kje na internetu je bil dokument dobljen in kdaj. Podatek o tem, kdaj je bil dokument dobljen, je pomemben zaradi pogostega spreminjanja www okolja.

Primer:

Urlich, W., 1983. Critical Heuristics of Social Planning. Chicago: University of Chicago Press, str. 45-100. http://www.mors.si/index.php?id=213, 17. 10. 2008. Pri navajanju zanimivih internetnih naslovov v besedilu (ne gre za navajanje posebnega dokumenta) zadošča navedba naslova (http://www.vpvs.uni-lj.si). Posebna referenca na koncu besedila $\mathrm{v}$ tem primeru ni potrebna.

Sklicevanje Pri sklicevanju na vire med besedilom navedite priimek avtorja, letnico izdaje in na vire stran. Primer: ... (Smith, 1997, str. 12) ...

Če dobesedno navajate del besedila, ga ustrezno označite z narekovaji, v oklepaju pa poleg avtorja in letnice navedite tudi stran besedila, iz katerega ste navajali.

Primer: ... (Smith, 1997, str. 15) ...

Če je avtor omenjen v besedilu, v oklepaju navedemo le letnico izida in stran (1997, str. 15).

Slike, diagrami

Slike, diagrami in tabele $\mathrm{v}$ prispevku naj bodo $\mathrm{v}$ posebej pripravljenih datotekah, in tabele ki omogočajo lektorske popravke. V besedilu mora biti jasno označeno mesto, kamor je treba vnesti sliko. Skupna dolžina prispevka ne sme preseči dane omejitve.

Diagrami se štejejo kot slike.

Vse slike in tabele se številčijo. Številčenje poteka enotno in ni povezano s številčenjem poglavij. Naslov slike je naveden pod sliko, naslov tabele pa nad tabelo. Navadno je v besedilu navedeno vsaj eno sklicevanje na sliko ali tabelo. Sklic na sliko ali tabelo je: ... (slika 5) ... (tabela 2$)$...

Primer slike: $\quad$ Primer tabele:

Tabela 2: Naslov tabele

Slika 5: Naslov slike 
Opombe Številčenje opomb pod črto je neodvisno od strukture besedila in se v vsakem pod črto prispevku začne s številko 1. Posebej opozarjamo avtorje, da so opombe pod črto namenjene pojasnjevanju misli, zapisanih v besedilu, in ne navajanju literature.

Kratice Kratice naj bodo dodane v oklepaju, ko se okrajšana beseda prvič uporabi, zato posebnih seznamov kratic ne dodajamo. Za kratico ali izraz v angleškem jeziku napišemo najprej slovensko ustreznico, v oklepaju pa angleški izvirnik in morebitno angleško kratico.

Format Uredniški odbor sprejema prispevke, napisane z urejevalnikom besedil MS Word.

zapisa

prispevka

Kontaktni Prispevkom naj bo dodan avtorjev elektronski naslov.

podatki

avtorja

Kako poslati Avtor pošlje prispevek na elektronski naslov odgovorne urednice.

prispevek

Potrjevanje Odgovorna urednica avtorju potrdi prejetje prispevka.

prejetja

prispevka

Korekture Avtor opravi korekture svojega prispevka v treh dneh.

Naslov Ministrstvo za obrambo

uredniškega Generalštab Slovenske vojske

odbora Sodobni vojaški izzivi

Uredniški odbor

Vojkova cesta 55

1000 Ljubljana

Slovenija

Elektronski naslov

Odgovorna urednica:

liliana.brozic@mors.si

Prispevkov, ki ne bodo urejeni skladno s tem navodilom, uredniški odbor ne bo sprejemal. 


\section{INSTRUCTIONS TO AUTHORS}

\section{Content-related guidelines}

General Contemporary Military Challenges is an interdisciplinary scientific and professional publication publishing articles on topical subjects, research, scientific and professional discourse, technical or social-science analyses in the field of security, defence and military, as well as reviews of scientific and professional monographs.

What do we We publish articles in Slovene with abstracts in English and, based on the Editorial publish? Board's decision, articles in English with abstracts in Slovene.

We publish articles, which have not been previously published or submitted to another journal for publication. The author is held accountable for all possible copyright violations. If the article has already been printed elsewhere, sent for publication or presented at a professional conference, the author must accordingly notify the editor, obtain the publisher's consent (if necessary) and indicate the reasons for republishing.

\section{Technical guidelines}

Length of the article

Peer reviews

Proofreading

Indicating the authors of the article
The length of articles should generally be 16 pages or 30,000 characters with spaces. The minimum length is 8 pages or 15,000 characters with spaces and the maximum length 24 pages or 45,000 characters with spaces.

Reviews of science or professional monographs should not exceed 3,000 characters with spaces.

All articles undergo an anonymous peer review. Based on the reviewer's assessment, the editorial board or the managing editor accept the article, demand it be notified or reject it. The author is obliged to take the reviewer's comments into consideration and adjust the article accordingly.

Due to an anonymous review procedure, the first page of the article should be designed in a way that the author's identity cannot be identified.

The final classification is determined by the editorial board.

Proofreading is provided by the organizational unit responsible for publishing activities. Proofread articles are distributed to respective authors for authorisation.

The name(s) of the author(s) should be indicated in the upper left corner and aligned left.

Example:

Name 1 Surname 1,

Name 2 Surname 2, 
Title of the article

Abstract

Key words

Text

formatting

About the author(s)

Text structuring
The title of the article is written below the name(s) of the author(s). The font of the title is bold, size 16 . The text of the title is centrally aligned.

The paper should include an abstract of a maximum of 800 characters (10 lines). The abstract should provide a concise presentation of the topic, particularly the results and the findings. General findings and reflections do not constitute a part of the abstract, but are rather included in the introduction.

\section{Key words (3-5) should be bold with a justified text alignment.}

The article should be formatted with 1.5 line spacing, font Arial, size 12. The text should have justified alignment, without indents.

The author(s) should prepare a short text about their professional or scientific work. The text should not exceed 600 characters with spaces (10 lines, 80 words) and should be placed at the end of the paper, after the bibliography.

Individual chapters should be separated by independent subtitles and numbered accordingly.

Example:

1 Introduction

2 Title of the chapter ( $1^{\text {st }}$ level $)$

2.1 Subtitle ( $2^{\text {nd }} 1$ evel $)$

2.1.1 Subtitle ( $3^{\text {rd }}$ level)

2.1.1.1 Subtitle ( $4^{\text {th }}$ level $)$

Bibliography Bibliography should include an alphabetical list of authors referred to in the article. Each reference has to comply with the Harvard referencing style.

Examples:

a) book

Surname, name (initial), year. Title. Place. Publishing House.

E.g. Urlich, W., 1983. Critical Heuristics of Social Planning. Chicago: University of Chicago Press.

b) journal

E.g. Samson, C., 1970. Problems of information studies in history. S. Stone, ed. Humanities information research. Sheffield: CRUS, 1980, pp 44-68. For individual articles in a journal, the pages where the article is located are also to be indicated at the end of each source, e.g.

c) article in a journal

Kolega, N., 2006. Slovenian coast sea flood risk. Acta geographica Slovenica. 46-2, pp 143-167. 
Referencing Internet sources are referenced the same as with printed ones, but are followed from the internet by the information about where on the Internet and when the document was obtained. The information when a document was obtained is important because of the frequent changes to the www environment.

Example:

Urlich, W., 1983. Critical Heuristics of Social Planning. Chicago: University of Chicago Press. pp. 45-100. http://www.mors.si/index.php?id=213, 17 October 2008.

When referencing interesting URLs in the text (not citing a particular document), only URL (e.g. http://www.vpvs.uni-lj.si) can be indicated and a separate reference at the end of the text is not necessary.

Citation When citing sources in the text, indicate the author's surname, the year of publication and page. Example: ..... (Smith, 1997, p 12) ...

When quoting a part of the text, put the text in the quotation marks, and indicate in the parentheses the author and year followed by the page of the quoted text. Example: ...(Smith, 1997, p 15) ...

Figures, Figures, diagrams and tables to be included in the article should be prepared in diagrams, separate files which allow for proofreading corrections. The location in the text tables where the image is to be inserted should be clearly indicated. The total length of the article may not exceed the given limit.

Diagrams are considered figures.

All figures and tables should be numbered. The numbering of figures should be uniform and is not connected with the numbering of chapters. The title of a figure is positioned beneath the figure while the title of the table is positioned above the table.

As a rule, at least one reference to a figure or a table is made in the article. Reference to a figure or a table is made as follows: ... (figure 5) ........ (table 2)

Example of a figure: $\quad$ Example of a table:

Table 2: Title of the table

Figure 5: Title of the figure

Footnotes The numbering of footnotes is independent of the structure of the text and begins with number 1 in each article. Authors should note that footnotes are intended to explain the ideas mentioned in the text and not to refer to the literature.

Acronyms Acronyms used in the article should be explained in parentheses when first used in the text. A separate list of acronyms is not necessary. 
File format The editorial board accepts only texts edited using a MS Word text editor.

of the article

Author's Each article should include the author's e-mail.

contact

Submission An electronic version of the article should be sent to the email of the managing of the article editor.

Confirmation Upon receiving the article via email, the managing editor confirms the receipt.

upon receipt

Corrections The author makes corrections to the article within three days.

$\begin{array}{lll}\text { Editorial } & \text { Ministrstvo za obrambo } & \text { Managing Editor’s email: } \\ \text { Board } & \text { Generalštab Slovenske vojske } & \text { liliana.brozic@mors.si } \\ \text { address } & \text { Sodobni vojaški izzivi } & \\ & \text { Uredniški odbor } & \\ & \text { Vojkova cesta } 55 & \\ & \text { 1000 Ljubljana } & \\ & \text { Slovenia } & \end{array}$

The Editorial Board will not accept articles, which are not in compliance with the above instructions. 

Sodobni vojaški izzivi - 23/št. 4

Vsebina

Liliana Brožič

UVODNIK

POSAMEZNIK, DRŽAVA, VARNOST

Liliana Brožič

EDITORIAL

INDIVIDUAL, STATE, SECURITY

Bruno Blažina

SAMOMORILNOST V POLICIJI

SUICIDALITY IN THE POLICE

Małgorzata Zielińska

JAVNO MNENJE O TERITORIALNI OBRAMBI POLJSKE

Joanna Łatacz

THE PUBLIC'S PERCEPTION OF THE TERRITORIAL DEFENCE

Joanna Zauer

FORCES IN POLAND

Gabriella

Ráczkevy-Deák

NASILNA DEJANJA NAD ZDRAVSTVENIMI USTANOVAMI IN NJIHOVIMI ZAPOSLENIMI NA MADŽARSKEM

VIOLENT ACTS AGAINST HEALTHCARE INSTITUTIONS AND WORKERS IN HUNGARY

Rok Filipčič

KULTURNA DEDIŠČINA IN NJENO VAROVANJE V ČASU OBOROŽENIH SPOPADOV

CULTURAL HERITAGE AND ITS PROTECTION IN ARMED CONFLICTS

Uroš Tovornik

RECENZIJA

GEOPOLITIKA SLOVENIJE

Uroš Tovornik

REVIEW

A GEOPOLITICS OF SLOVENIA

Liliana Brožič

RECENZIJA

MIROVNIKI V DARFURJU

Liliana Brožič

REVIEW

DARFUR PEACEKEEPERS

David Humar

RECENZIJA

O VOJAŠKIH STRATEGIJAH

David Humar

REVIEW

ON MILITARY STRATEGIES

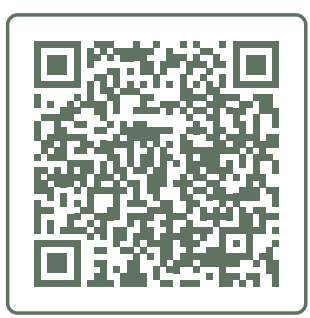

